\author{
Universidade de Brasília \\ Instituto de Ciências Exatas \\ Departamento de Matemática
}

\title{
Uso de atividades didáticas contextualizadas para estimular o aprendizado de geometria.
}

\author{
por \\ André Luis Santos Martinez
}

Brasília

2016

Universidade de Brasília

Instituto de Ciências Exatas 


\section{Uso de atividades didáticas contextualizadas para estimular o aprendizado de geometria.}

$$
\text { por }
$$

\section{André Luis Santos Martinez *}

Dissertação apresentada ao Departamento de Matemática da Universidade de Brasília, como parte dos requisitos do "Programa" de Mestrado Profissionalizante em Matemática em Rede Nacional - PROFMAT, para obtenção do grau de

\section{MESTRE}

Brasília, 07 de junho de 2016

Comissão Examinadora:

$$
\begin{aligned}
& \hline \text { Dr. Mauro Luiz Rabelo - MAT/UnB - Orientador } \\
& \hline \text { Dra. Nara Maria Pimentel - FE/UnB - Examinadora } \\
& \text { Dr. Helder de Carvalho Matos - MAT/UnB - Examinador }
\end{aligned}
$$

\footnotetext{
${ }^{*} \mathrm{O}$ autor foi bolsista do CAPES durante a elaboração deste trabalho.
} 
"A geometria é uma ciência de todas as espécies possíveis de espaços."

Immanuel Kant 


\section{Agradecimentos}

Chego ao final de uma acadêmica em que aprendi muito, foram um pouco mais de dois anos dedicados ao aprendizado da matemática, nos quais passaram muitos incentivadores.

Agradeço aos meus colegas de turma do PROFMAT por estarem estes dois anos apoiando, estudando, incentivando meu crescimento. E também a todos os professores por transmitirem seu conhecimento, e em especial ao meu orientador deste trabalho, Mauro Luiz Rabelo, pela ajuda na direção, instrução, referência e correções durante este período, que faz parte da composição da banca examinadora, como presidente. Agradeço também aos outros membros da banca, Nara Maria Pimentel e Helder de Carvalho Matos.

À minha família que sempre esteve ao meu lado e me incentivou nos estudos, sempre me apoiando e incentivando a progredir. Em especial agradeço também pelos mesmos motivos a Micaelen de Araujo Santana que, além do apoio e incentivo, sempre esteve junto de mim, por maiores dificuldades pelas quais passei. Para estes dedico esta obra.

Gostaria de também de demonstrar meu agradecimento ao professor que cedeu sua turma para a pesquisa, aos alunos que participaram das aulas e responderam ao questionário, a escola por ter cedido o espaço.

Ao Departamento da Universidade de Brasília, à CAPES pela bolsa de estudos, à Universidade de Brasília, à Secretaria de Educação do Distrito Federal por aceitar meu pedido de licença para estudos e ao PROFMAT.

A todos estes referidos e aqueles que ajudaram indiretamente meus sinceros agradecimentos. 


\section{Resumo}

Muito se comenta a respeito do desinteresse dos jovens nas aulas de matemática, ministradas, em sua maioria, no modelo tradicional de transmissão-recepção. Em geral, o professor desenvolve os tópicos de conteúdo de forma abstrata, sem apelo para as aplicações e sem apresentar os contextos nos quais podem ser empregados. Para contribuir no aprimoramento desse debate, propõe-se um trabalho diferenciado em sala de aula que possa ajudar os estudantes a compreender melhor os conteúdos matemáticos abordados, por meio de atividades didáticas contextualizadas que estimulem o aprendizado de matemática na educação básica. Nessa perspectiva, elegeu-se a geometria como foco de estudo, e foram criados alguns exemplos de atividades contextualizadas que envolvem conceitos desse campo da matemática. Essas atividades foram aplicadas durante duas semanas em quatro turmas do ensino médio de uma escola pública do Distrito Federal, incluindo-se um desafio de criação em grupo de uma atividade análoga àquelas a que foram submetidos. Ao final, os estudantes responderam a um questionário de percepção sobre o seu aprendizado. Os resultados foram analisados do ponto de vista da estatística descritiva e da análise de conteúdo, revelando-se que os estudantes se sentiram mais motivados para o estudo da geometria e consequentemente da matemática. Como forma de preparar para o desenvolvimento do tema central do trabalho - uso de atividades didáticas contextualizadas para estimular o aprendizado de geometria-, faz-se uma discussão sobre o desempenho dos alunos em matemática nas avaliações de larga escala aplicadas no Brasil, com enfoque na parte de geometria, apresenta-se uma breve análise do livro didático adotado na escola pesquisada e desenvolvem-se os conteúdos matemáticos que darão suporte para a criação das atividades aplicadas.

Palavras-chaves: Geometria; atividades contextualizadas; desempenho; resultados; avaliação; aprendizagem. 


\section{Abstract}

Much is said about the lack of interest of young people in Math classes, taught mostly in the traditional model of transmission-reception. In general, the teacher develops content topics abstractly without appeal for the applications and without showing the contexts in which they can be employed. To contribute to the improvement of this debate, it is proposed a different work in classroom that can help students understand better the Math contents through contextualized learning activities that stimulate the learning of Math in basic education. In this perspective, Geometry was chosen as a focus of study and some examples of contextualized activities that involve concepts of that Mathematics field. These activities have been applied for two weeks in four school classes of high school in a public school in the Federal District, including a challenge to create, in group, some activity similar to those that they were submitted. At the end, students answered a perception survey regarding to their learning. The results were analyzed from the point of view of descriptive statistics and content analysis, revealing that the students felt more motivated to study Geometry and thereafter Math. In order to prepare for the central theme of the work ? use of contextualized learning activities to stimulate learning geometry ? a discussion about the performance of students in Math in large-scale assessments applied in Brazil has to take place, focusing on Geometry, showing a brief analysis of the textbook adopted in the researched school and developing mathematical content that will support the creation of activities applied.

Key-words: Geometry; contextualized activities; performance; results; evaluation; learning. 


\section{Sumário}

$\begin{array}{ll}\text { Introdução } & 1\end{array}$

1 Desempenho dos estudantes nas avaliações nacionais 5

1.1 Proposta da Base Nacional Comum Curricular para o ensino de geometria 6

1.2 Parâmetros e avaliações nacionais . . . . . . . . . . . . . . 9

1.3 Escolha do livro didático . . . . . . . . . . . . . . . . . . 11

1.4 Breve análise do livro didático adotado na escola pesquisada . . . . . . . 12

1.5 Saeb . . . . . . . . . . . . . . . . . . 13

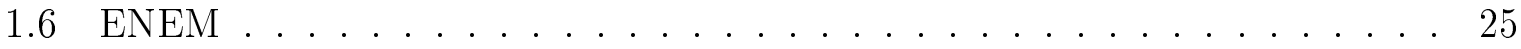

1.7 Dificuldades no ensino de geometria . . . . . . . . . . . 27

2 Breve histórico e pré-requisitos de geometria 32

2.1 Breve história da geometria . . . . . . . . . . . . . . 32

2.2 Geometria Euclidiana . . . . . . . . . . . . . . . . . . 35

2.2 .1 Noções primitivas . . . . . . . . . . . . . . 36

2.2 .2 Proposições e postulados . . . . . . . . . . . . . . 37

2.3 Triângulos, quadriláteros e outros polígonos . . . . . . . . . . . . 43

2.3 .1 Triângulos . . . . . . . . . . . . . . . . . 43

2.3 .2 Quadriláteros . . . . . . . . . . . . . . . . . 45

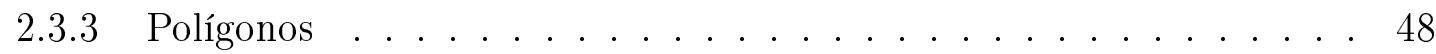

2.4 Circunferência e círculo . . . . . . . . . . . . . . . . . . . . . . . 49

2.4.1 Propriedades importantes envolvendo a circunferência e o círculo . . 51

2.5 Área de superfícies planas . . . . . . . . . . . . . . . . . 52

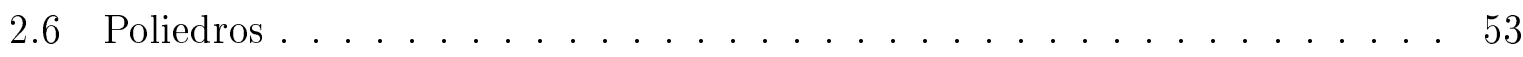

2.6 .1 Poliedros notáveis . . . . . . . . . . . . . . 54

2.6 .2 Outros poliedros . . . . . . . . . . . . . . . . 54 
3 Algumas atividades contextualizadas e práticas para serem trabalhadas com os alunos $\quad 58$

$3.1 \quad$ Jogo de dardo . . . . . . . . . . . . . . . . . 58

3.2 Construção de uma ponte em miniatura $\ldots \ldots \ldots \ldots$. . . . . . 60

3.3 Cálculo de alturas pela sombra . . . . . . . . . . . . . . 61

3.4 Volumes de prismas e pirâmides . . . . . . . . . . . . . . . 61

3.5 Volume da esfera a partir de um cilindro e um cone . . . . . . . . . . . 63

3.6 Geometria do motorista de táxi . . . . . . . . . . . . . . 64

3.7 Geometria em uma esfera (Riemanniana) . . . . . . . . . . . . . 65

3.8 Criação de uma nova atividade em geometria . . . . . . . . . . . . 65

4 Metodologia e resultados das atividades $\quad 66$

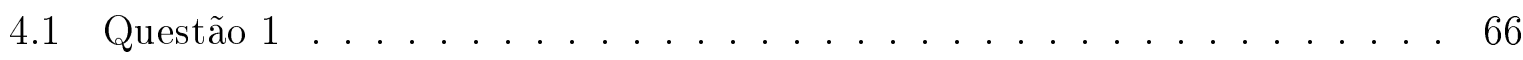

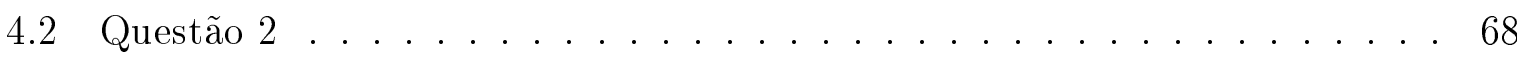

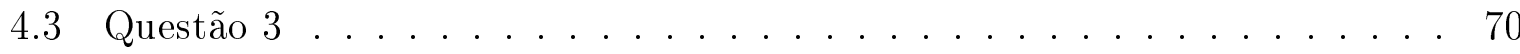

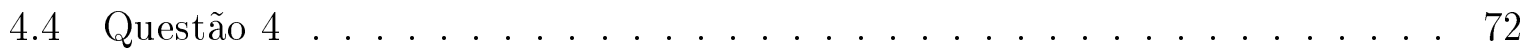

4.4.1 Resumo das atividades criadas pelas turmas . . . . . . . . 74

4.4.2 Possíveis causas para a não realização da atividade por parte da turma ..................... 76

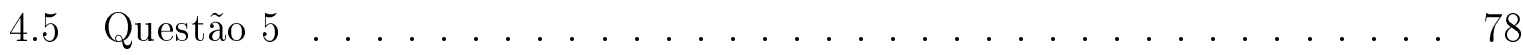

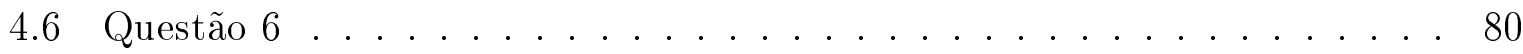

5 Considerações finais $\quad 83$

5.1 Considerações sobre as avaliações nacionais . . . . . . . . . . . . . . 84

5.2 Considerações sobre as atividades aplicadas . . . . . . . . . . . 84

6 Anexo - Questionário $\quad 86$

7 Anexo - Respostas à questão $6 \quad 89$

$\begin{array}{lr}\text { Referências Bibliográficas } & 92\end{array}$ 


\section{Lista de Figuras}

1.1 Exemplo de questão da Prova Brasil. 9 ensino fundamental (INEP, 2015). 15

1.2 Níveis 11 e 12 de desempenho dos alunos de matemática, (INEP, 2015). . . 17

1.3 Exemplo 2 de questão da Prova Brasil, (INEP, 2015) . . . . . . . . . . . 18

1.4 Nível 9 de desempenho dos alunos em matemática, (INEP, 2015). . . . . . 20

1.5 Figura de um polígono refeita a partir de uma questão de: http://simposio.profmatsbm.org.br/docs/Mesa-redonda-MauroRabelo.pdf. . . . . . . . . . . 22

1.6 Imagem para resolução do exemplo $2 \ldots$. . . . . . . . . . . . . . . . . 24

1.7 Questão 142 - ENEM 2014. . . . . . . . . . . . . . 26

2.1 Ponto P. . . . . . . . . . . . . . . . 36

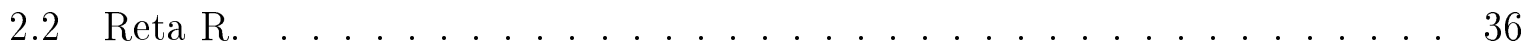

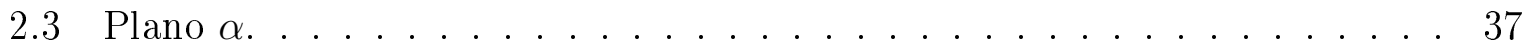

2.4 Retas concorrentes. . . . . . . . . . . . . . . 38

2.5 Retas reversas. . . . . . . . . . . . . . . . . 39

2.6 Retas paralelas. . . . . . . . . . . . . . . . 40

2.7 Retas perpendiculares. . . . . . . . . . . . . . . . 41

2.8 Reta $r$ em outro plano que não contenha $t$ e $s$ e ortogonal ao plano. . . . 42

2.9 Figura proposição $2.2 \ldots \ldots$. . . . . . . . . . . . . . 42

2.10 Figura proposição $2.3 \ldots \ldots$. . . . . . . . . . . . . . . 43

2.11 Triângulo ABC. . . . . . . . . . . . . . . . . 44

2.12 Quadriláteros notáveis. . . . . . . . . . . . . . . 46

2.13 Trapézio semi-soma das bases. . . . . . . . . . . . . . . . . 48

2.14 Circunferência e círculo. . . . . . . . . . . . . . . . . 49

2.15 Setor circular, o interior de OA, OB e $\overparen{A B} \ldots \ldots \ldots . \ldots$

2.16 Segmento circular. . . . . . . . . . . . . . . . 50

2.17 Figura propriedade a) . . . . . . . . . . . . . 51 
2.18 Figura propriedade b) . . . . . . . . . . . . . . 51

2.19 Prisma. . . . . . . . . . . . . . . . . 55

2.20 Pirâmide. . . . . . . . . . . . . . . . . . 55

2.21 Cilindro e cone. . . . . . . . . . . . . . . . 56

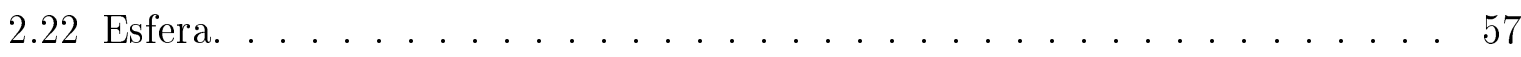

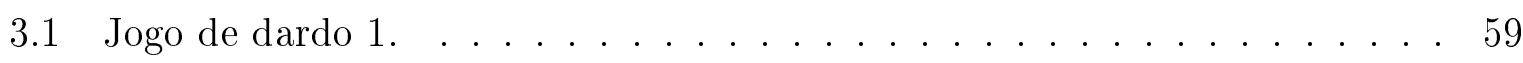

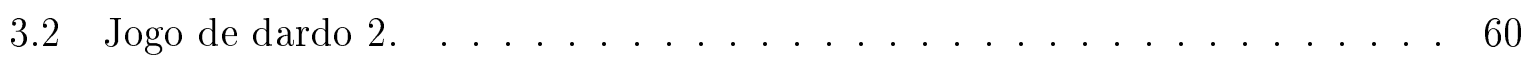

3.3 Imagens prisma e pirâmide feitas com canudos com indicação de corte com canudos brancos. ........................ 62

3.4 Imagens prisma e pirâmide feitas com canudos com indicação de corte com canudos brancos. ....................... 62

3.5 Isopor em formato de uma meia-esfera . . . . . . . . . . . . 63

3.6 Cone com um cilindro feito com papel para se comparar com o volume da

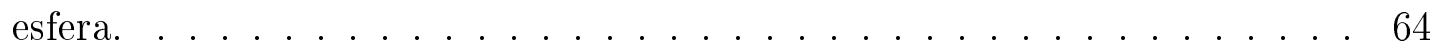

4.1 Porcentagem às respostas da questão 1. . . . . . . . . . . . . . 6 67

4.2 Porcentagem às respostas da questão $2 \ldots \ldots$. . . . . . . . . . 68

4.3 Gráfico das respostas à questão: descreva em qual situação conheceu a(s)

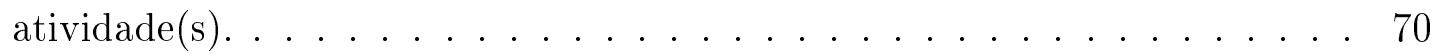

4.4 Quantitativo de respostas à questão 3. . . . . . . . . . . . . . 71

4.5 Quantitativo de respostas à questão 4: Quanto à atividade criada em sala pela turma, o que você percebeu? . . . . . . . . . . . . 73

4.6 Exemplo da atividade, onde "I"é a posição inicial e "F", a posição final, as setas em preto são as direções que podem ser seguidas, e as setas em vermelho são as posições que não podem ser seguidas. . . . . . . . . . . 75

4.7 Porcentagem às respostas da questão $5 \ldots$. . . . . . . . . . . . . . 79 


\section{Lista de Tabelas}

1.1 Níveis 11 e 12 de desempenho dos alunos de matemática, (INEP, 2015) 16

1.2 Nível 9 de desempenho dos alunos de matemática, (INEP, 2015) . . . . . 19

1.3 Evolução da proporção de alunos com aprendizado adequado à série no Brasil (1999-2011), em \% . . . . . . . . . . . . 21

1.4 índices de respostas ao item do exemplo $1 \ldots \ldots$. . . . . . . . . 22

1.5 Percentual de respostas ao exemplo $2 \ldots \ldots$. . . . . . . . . . 24

2.1 Polígonos e suas respectivas áreas. . . . . . . . . . . . . . 53

4.1 Quantitativo de respostas à questão 1: Seu interesse pelas atividades foi . . 67

4.2 Quantitativo de respostas à questão 2: Você já conhecia alguma dessas atividades? ......................... 68

4.3 Quantitativo de respostas à questão complementar à 2: As situações em que foram vistas as atividades: Caso tenha marcado as opções B, C, D ou E, descreva em qual situação conheceu a(s) atividade(s): . . . . . . . 69

4.4 Quantitativo de respostas à questão 3: Marque as 2 atividades com que mais gostou de trabalhar e estudar. . . . . . . . . . . . 71

4.5 Quantitativo de respostas à questão 4: Quanto à atividade criada em sala pela turma, o que você percebeu? . . . . . . . . . . . . . . 72

4.6 Quantitativo de respostas à questão 5: O que você aprendeu com essas atividades? (Pode marcar mais de uma resposta) . . . . . . . . . 78

4.7 Categorias e exemplos de frases. . . . . . . . . . . . . . 81 


\section{Introdução}

A cada dia vemos que há uma distância muito grande entre a realidade do aluno e os conteúdos aplicados nas aulas de matemática. O estudante não tem interesse em pesquisar, aprofundar seus conhecimentos e se aperfeiçoar. E a geometria do seu cotidiano nem sempre é a que está presente em sala de aula, o que torna o processo de ensino e aprendizagem mais difícil. Os Parâmetros Curriculares Nacionais (PCN) do ensino médio em sua apresentação já trazem um referencial de como se deve desenvolver o trabalho:

Tais referenciais já direcionam e organizam o aprendizado, no Ensino Médio, das Ciências da Natureza, Matemática e suas Tecnologias, no sentido de se produzir um conhecimento efetivo, de significado próprio, não somente propedêutico. De certa forma, também organizam o aprendizado de suas disciplinas, ao manifestarem a busca de interdisciplinaridade e contextualização e ao detalharem, entre os objetivos educacionais amplos desse nível de ensino, uma série de competências humanas relacionadas a conhecimentos matemáticos e científico-tecnológicos. Referenda-se uma visão do Ensino Médio de caráter amplo, de forma que os aspectos e conteúdos tecnológicos associados ao aprendizado científico e matemático sejam parte essencial da formação cidadã de sentido universal e não somente de sentido profissionalizante.

(PCN, v.3, p. 4)

Essa visão confirma a tese de que um trabalho voltado para a interdisciplinaridade e contextualização torna mais amplo o aprendizado e o faz útil à vida e ao trabalho. Faz com que o estudante adquira competências, habilidades que vão além da aprendizagem mecânica de apenas resolver exercícios, de repetir procedimentos rotineiros, mas de interpretar, julgar, analisar e adquirir aprendizado que possa aplicar posteriormente.

A recomendação de contextualização serve, dessa forma, a esses mesmos propósitos. Essa seção é aberta com um texto introdutório, de caráter mais 
geral, que apresenta sinteticamente os objetivos educacionais da área, revelando como estes se realizam em direta associação com os objetivos explícitos das outras duas áreas nas quais se organiza o Ensino Médio.

(PCN, v.3, p. 4)

Portanto, um trabalho voltado para a contextualização melhora o processo de ensinoaprendizado e faz com que o professor busque um conhecimento muitas vezes interdisciplinar para que o conhecimento seja aplicado ao cotidiano dos seus estudantes. Não se trata de uma visão utilitarista de todo o conhecimento ensinado na escola, mas de uma perspectiva de se fazer um esforço de mostrar para o estudante algumas aplicações dos conteúdos aprendidos no cotidiano, de modo a motivá-lo para prosseguir os estudos e despertar o interesse pelo aprendizado.

O professor que trabalha os conteúdos de forma contextualizada não domina apenas o conteúdo específico de sua área de atuação, mas precisa ir além, porque deve saber aplicálos em diversas áreas, necessitando, assim, de formação e atualização contínua. Conforme afirma Perrenoud:

Conhecer os conteúdos a serem ensinados é a menor das coisas quando se pretende instruir alguém, porém a verdadeira competência pedagógica não está aí; ela consiste, de um lado, em relacionar conteúdos a objetivos e, de outro a situações de aprendizagem.

(PERRENOUD 2000, pag. 11)

Essa postura constitui um desafio para a atuação docente e, por isso, o que mais se observa é uma atitude passiva do professor de matemática, que, na maioria das vezes, prefere repetir no quadro o conteúdo proposto no livro didático e passar uma lista infindável de exercícios descontextualizados para os estudantes, deixando-os à deriva, imaginando que o interesse vai brotar por si só. O modelo transmissão-recepção é, de longe, o predominante no ensino de matemática na educação brasileira.

Com 4 anos de atuação em turmas de matemática do ensino fundamental e médio e sentindo cada vez mais esse distanciamento dos conteúdos de suas aplicações e a falta de interesse dos estudantes, decidi investigar se a motivação deles aumentaria, caso fossem desenvolvidos conteúdos a partir de atividades contextualizadas. Meu foco de atenção foi voltado para a geometria, um campo de conhecimento da matemática que deveria ser bem apreciado pelos estudantes, devido à riqueza com que comparece no mundo ao nosso redor.

Assim, este trabalho tem o objetivo principal de avaliar se o aprendizado do aluno em geometria é estimulado a partir da exploração, análise, desenvolvimento e aplicação de atividades didáticas contextualizadas em situações do cotidiano. 
Para se atingir esse objetivo, em um momento inicial, será abordado como está o nível de aprendizado dos estudantes brasileiros em matemática e, em especial, na geometria, analisando-se como são abordados os conteúdos de geometria nas provas nacionais e os resultados apresentados pelos estudantes nas questões que envolvem conhecimentos geométricos. Em seguida, será desenvolvida a base de conteúdos para as atividades contextualizadas e práticas do próximo capítulo, que também serve como sugestão de trabalho para os professores do ensino fundamental e médio. Em seguida, será feito um estudo do resultado da aplicação dessas atividades a um grupo de estudantes dos segundos e terceiros anos de uma escola pública do ensino médio por meio de um questionário de percepção que avalia o quanto essas atividades interferem no aprendizado e estimulam o estudo e a vontade de aprender. Os resultados obtidos serão apresentados e analisados no capítulo 4.

As atividades contextualizadas propostas neste trabalho pretendem fazer com que o aluno estude em grupo ou individualmente, de forma diferenciada, e também consiga ter a visão geométrica bidimensional ou espacial de objetos que muitas vezes fica comprometida com um desenho rabiscado pelo professor no quadro-negro. Espera-se que isso seja também uma motivação para seu aprendizado.

Muitos livros e escolas esperam que o aluno aprenda somente com a "ameaça da nota baixa"ou de um futuro promissor, mas isso faz com que o aprendizado do aluno seja momentâneo, com a finalidade única de fazer a prova e estudar. Ao ser desafiado com atividades diferenciadas e diversificadas, o estudante adquire um aprendizado que poderá aplicar em outras situações, conforme afirma Perrenoud:.

Se a escola quisesse criar e manter o desejo de saber e a decisão de aprender, deveria diminuir consideravelmente seus programas, de maneira a integrar em um capítulo tudo que permita aos alunos dar-lhe sentido e ter vontade de apropriar desse conhecimento. Ora, os programas são concebidos para alunos cujo interesse, desejo de saber e vontade de aprender são supostamente adquiridos e estáveis.

(PERRENOUD 2000, p. 69)

Daí surgem, naturalmente, as clássicas perguntas que eles dirigem, ano após ano, ao professor:

- Pra que serve isso (matemática ou geometria)?

- Onde vou usar isso professor?

O professor deve saber que o aluno não vê esse conteúdo aplicado em sua vida e precisa dar uma resposta para ele. A resposta não pode ser aquela que muitas vezes nos foi dada 
por alguns mestres: quando você chegar na universidade você vai saber para que serve esse conteúdo. Ou como alguns, infelizmente dizem: isso precisa ser estudado porque cai no vestibular e no Enem. É preciso romper com essa lógica e, nessa perspectiva, é que foi desenvolvido este trabalho, com o intuito de propor atividades que estimulem o desejo de aprender e que façam o aluno se envolver em seu projeto pessoal. Nesse sentido, o professor vai precisar, conforme exemplo de atividades desenvolvidas neste trabalho, buscar textos e atividades aplicadas, exercícios de matemática voltados para o cotidiano.

A pesquisa aqui desenvolvida revelou a percepção dos estudantes que foram submetidos à proposta diferenciada de atividades de geometria contextualizadas, indicando, de acordo com a opinião deles, que o caminho parece adequado para estimular o interesse pela matemática. 


\section{$\left[\begin{array}{c}\text { Coptutuo } \\ 1\end{array}\right]$ \\ Desempenho dos estudantes nas avaliações nacionais}

Os resultados de desempenho nas avaliações de larga escala aplicadas no Brasil, a exemplo da Prova Brasil e do Sistema de Avaliação da Educação Básica (SAEB), confirmam que a matemática tem sido marcada pelos altos índices de reprovação e pelo baixo nível de aprendizado dos estudantes. Os professores, em geral, apenas seguem o livro didático escolhido pela escola em que atuam, por vários motivos: o pouco tempo de que dispõem para preparar as aulas, a falta de infraestrutura e de recursos materiais nas escolas, a pouca clareza das recomendações dos órgãos públicos responsáveis pelas políticas educacionais ou a dificuldade de as recomendações chegarem aos professores, e até mesmo a ausência de incentivo ao aperfeiçoamento do docente.

O ensino de Matemática costuma provocar duas sensações contraditórias, tanto por parte de quem ensina, como por parte de quem aprende: de um lado, a constatação de que se trata de uma área de conhecimento importante; de outro, a insatisfação diante dos resultados negativos obtidos com muita frequência em relação à sua aprendizagem.

(PCN, livro 3) 


\subsection{Proposta da Base Nacional Comum Curricular para o ensino de geometria}

Desde o ano passado (2015), o Brasil começou a discutir uma proposta de estabelecimento de conhecimentos básicos que todos os estudantes brasileiros têm o direito de ter acesso e se apropriar durante sua trajetória na Educação Básica, intitulada Base Nacional Comum Curricular (BNC), como cumprimento ao que estabelece o Plano Nacional da Educação (Lei 13.005/2014), na meta 2014/2024. De acordo com o respectivo portal eletrônico elaborado pelo MEC:

A Base Nacional Comum Curricular (BNC) vai deixar claro os conhecimentos essenciais aos quais todos os estudantes brasileiros têm o direito de ter acesso e se apropriar durante sua trajetória na Educação Básica, ano a ano, desde o ingresso na Creche até o final do Ensino Médio. Com ela os sistemas educacionais, as escolas e os professores terão um importante instrumento de gestão pedagógica e as famílias poderão participar e acompanhar mais de perto a vida escolar de seus filhos.

A Base será mais uma ferramenta que vai ajudar a orientar a construção do currículo das mais de 190 mil escolas de Educação Básica do país, espalhadas de Norte a Sul, públicas ou particulares.

Com a BNC, ficará claro para todo mundo quais são os elementos fundamentais que precisam ser ensinados nas Áreas de Conhecimento: na Matemática, nas Linguagens e nas Ciências da Natureza e Humanas.

A Base é parte do Currículo e orienta a formulação do projeto PolíticoPedagógico das escolas, permitindo maior articulação deste. A partir da Base, os mais de 2 milhões de professores continuarão podendo escolher os melhores caminhos de como ensinar e, também, quais outros elementos (a Parte Diversificada) precisam ser somados nesse processo de aprendizagem e desenvolvimento de seus alunos. Tudo isso respeitando a diversidade, as particularidades e os contextos de onde estão.

A Base é uma conquista social. Sua construção é crucial para encontrarmos um entendimento nacional em torno do que é importante no processo de desenvolvimento dos estudantes brasileiros da Educação Básica. Entender seu real significado e participar da sua construção é direito e dever de todos. 
Pela proposta apresentada na Base Nacional Comum Curricular (BNC), os estudantes de todo o país devem ter um conhecimento essencial durante toda sua trajetória do ensino básico, desde a creche até o final do ensino médio. Assim todas as escolas, tanto públicas quanto particulares, terão a Base como ferramenta para ajudar a fazer o currículo. Na proposta que está em discussão, a matemática tem como objetivo pela BNC os seguintes pontos:

- Estabelecer conexões entre os eixos da Matemática e entre essa e outras áreas do saber.

- Resolver problemas, criando estratégias próprias para sua resolução, desenvolvendo imaginação e criatividade.

- Raciocinar, fazer abstrações com base em situações concretas, generalizar, organizar e representar.

- Comunicar-se, utilizando as diversas formas de linguagem empregadas em Matemática.

- Utilizar a argumentação matemática apoiada em vários tipos de raciocínio.

(BRASIL, 2015)

Sabe-se que o estudo da geometria constitui instrumento fundamental para se fazer essa ligação e se concretizarem os objetivos listados acima. Ao se relacionar uma figura como uma bola de futebol, seus aspectos, suas propriedades e como ela se faz presente no dia a dia, trabalha-se com os alunos aspectos como resolução de problemas, comparação com outras formas geométricas e abstrações, entre outros.

Dessa forma, a Matemática pode ser vista como uma fonte de modelos para os fenômenos que nos cercam. Esses modelos compreendem não somente os conceitos, mas as relações entre eles, procedimentos e representações de diversas ordens.

(BNC, 2015)

O que se pode observar também é que, na proposta da Base Nacional Comum, os conhecimentos matemáticos são separados nas séries (anos) em que o aluno se encontra. Isso pode ajudar o professor a verificar se o que está lecionando é o mesmo que os outros 
estão nas demais escolas brasileiras, garantindo-se um nível mínimo de conhecimento da área a todos os estudantes, independentemente do local de moradia e do tipo de escola que frequentam. Por exemplo, para o segundo ano do ensino médio, foram elencados os seguintes objetivos em geometria:

- Utilizar o conceito de vetor para associar duas figuras congruentes à composição de transformações no plano (reflexão, translação e rotação), com ou sem o uso de tecnologias digitais.

- Compreender o conceito de lugar geométrico (exemplo: mediatriz, bissetriz, circunferência).

- Resolver problemas, envolvendo figuras poligonais determinadas pelas coordenadas de seus vértices, incluindo o cálculo da distância entre dois pontos.

- Reconhecer características e elementos de poliedros (exemplo: faces, arestas, vértices, diagonais), incluindo poliedros regulares, prismas e pirâmides oblíquos.

Esses objetivos guardam relação direta com aqueles estabelecidos para grandezas e medidas, que são:

- Compreender o princípio de Cavalieri e utilizá-lo para estabelecer as fórmulas para o cálculo da medida do volume de figuras geométricas espaciais.

- Resolver e elaborar problemas de cálculo da medida do volume de cilindros, prismas, pirâmides e cones retos.

(BNC, 2015)

Um dos objetivos da BNC é relacionar os conhecimentos entre as áreas da matemática, como aritmética, álgebra e geometria com outras áreas afins e aplicadas de conhecimento como física e química. Daí se infere também a importância dada ao ensino da geometria.

A matemática deve ter uma ligação entre suas áreas e a geometria, pois esta tem aplicações básicas, como medir, observar os espaços entre outras aplicações. 
A Aritmética e a Geometria formaram-se a partir de conceitos que se interligavam. Talvez, em consequência disso, tenha se generalizado a ideia de que a Matemática é a ciência da quantidade e do espaço, uma vez que se originou da necessidade de contar, calcular, medir, organizar o espaço e as formas. $\mathrm{O}$ desenvolvimento da Geometria e o aparecimento da Álgebra marcaram uma ruptura com os aspectos puramente pragmáticos da Matemática e impulsionaram a sistematização dos conhecimentos matemáticos, gerando novos campos: Geometria Analítica, Geometria Projetiva, Álgebra Linear, entre outros. O estudo das grandezas variáveis deu origem ao conceito de função e fez surgir, em decorrência, um novo ramo: a Análise Matemática.

(PCN, livro 3)

\subsection{Parâmetros e avaliações nacionais}

De acordo com os Parâmetros Curriculares Nacionais (PCN), os problemas de geometria envolvem os conhecimentos de espaço e forma e de grandezas e medidas. Para isso, no primeiro ciclo do ensino fundamental, o aluno deve:

- Resolver situações-problema de localização e deslocamento de pontos no espaço, reconhecendo nas noções de direção e sentido, de ângulo, de paralelismo e de perpendicularismo, elementos fundamentais para a constituição de sistemas de coordenadas cartesianas;

- Estabelecer relações entre figuras espaciais e suas representações planas, envolvendo a observação das figuras sob diferentes pontos de vista, construindo e interpretando suas representações;

- Resolver situações-problema que envolvam figuras geométricas planas, utilizando procedimentos de decomposição e composição, transformação, ampliação e redução.

- Ampliar e construir noções de medida, pelo estudo de diferentes grandezas, a partir de sua utilização no contexto social e da análise de alguns dos problemas históricos que motivaram sua construção;

- Resolver problemas que envolvam diferentes grandezas, selecionando unidades de medida e instrumentos adequados à precisão requerida. 
(PCN,v. 3, p.47)

E, no segundo ciclo do ensino fundamental:

- Interpretar e representar a localização e o deslocamento de uma figura no plano cartesiano; produzir e analisar transformações e ampliações/reduções de figuras geométricas planas, identificando seus elementos variantes e invariantes, desenvolvendo o conceito de congruência e semelhança;

- Ampliar e aprofundar noções geométricas como incidência, paralelismo, perpendicularismo e ângulo para estabelecer relações, inclusive as métricas, em figuras bidimensionais e tridimensionais.

- Ampliar e construir noções de medida, pelo estudo de diferentes grandezas, utilizando dígitos significativos para representar as medidas, efetuar cálculos e aproximar resultados de acordo com o grau de precisão desejável;

- Obter e utilizar fórmulas para cálculo da área de superfícies planas e para cálculo de volumes de sólidos geométricos (prismas retos e composições desses prismas).

(PCN,v.3, p.51-52)

Ao se estabelecer um primeiro conjunto de parâmetros para a organização do ensino de Matemática no Ensino Médio, pretende-se contemplar a necessidade da sua adequação para o desenvolvimento e promoção de alunos, com diferentes motivações, interesses e capacidades, criando condições para a sua inserção em um mundo em mudança e contribuindo para desenvolver as capacidades que deles serão exigidas em sua vida social e profissional.

(PCN ENSINO MÉDIO, p.40)

Já no ensino médio, a finalidade está envolvida com outras competências e habilidades:

- Compreender os conceitos, procedimentos e estratégias matemáticas que permitam a ele desenvolver estudos posteriores e adquirir uma formação científica geral; 
- Aplicar seus conhecimentos matemáticos a situações diversas, utilizandoos na interpretação da ciência, na atividade tecnológica e nas atividades cotidianas;

- Analisar e valorizar informações provenientes de diferentes fontes, utilizando ferramentas matemáticas para formar uma opinião própria que lhe permita expressar-se criticamente sobre problemas da Matemática, das outras áreas do conhecimento e da atualidade;

- Desenvolver as capacidades de raciocínio e resolução de problemas, de comunicação, bem como o espírito crítico e criativo;

- Utilizar com confiança procedimentos de resolução de problemas para desenvolver a compreensão dos conceitos matemáticos;

- Expressar-se oral, escrita e graficamente em situações matemáticas e valorizar a precisão da linguagem e as demonstrações em Matemática;

- Estabelecer conexões entre diferentes temas matemáticos e entre esses temas e o conhecimento de outras áreas do currículo;

- Reconhecer representações equivalentes de um mesmo conceito, relacionando procedimentos associados às diferentes representações;

- Promover a realização pessoal mediante o sentimento de segurança em relação às suas capacidades matemáticas, o desenvolvimento de atitudes de autonomia e cooperação.

(PCN,v.3, p.51 E 52)

Pelo que dizem os PCN, pode-se fazer uma breve análise do livro didático adotado na escola pesquisada, localizada no Distrito Federal.

\subsection{Escolha do livro didático}

Mas antes de se analisar o livro didático, deve-se saber como é feita a escolha do livro pelas escolas de acordo com o Programa Nacional do Livro Didático (PNLD).

Pelo (PNLD), os livros a serem adotados pelas escolas públicas são escolhidos a cada triênio, em ciclos alternados. Assim, a cada ano, o Fundo Nacional de Desenvolvimento da 
Educação (FNDE) adquire e distribui os livros didáticos de determinada etapa de ensino e repõe e complementa os livros didáticos de outras etapas, ou seja, se um livro foi escolhido no ano de 2015, apenas em 2018 poderá ser feita uma nova escolha, e, durante esses três anos, são repostos os livros que não são mais possíveis de serem utilizados por vários motivos, como mal uso ou rasgados. A tarefa de professores e da equipe pedagógica é a escolha dos livros a serem adotados pela escola, a partir das coleções sugeridas no Guia de Livros Didáticos, que são analisadas a partir de resenhas (PNLD 2015). No ano de 2015, foi feita a escolha dos livros didáticos do ensino médio e reposição dos anos anteriores, em 2014, a escolha dos livros dos livros didáticos do ensino fundamental do $6^{\circ}$ ao $9^{\circ}$ anos e, em 2013, do ensino fundamental do $1^{\circ}$ ao $5^{\circ}$ anos, com a reposição dos outros livros de etapas anteriores, fazendo sempre esse ciclo. Assim, no ano de 2016 voltarão a ser escolhidos os livros do ensino fundamental do $1^{\circ}$ ao $5^{\circ}$ anos. Desse modo,segundo o FNDE (2015) "os livros de cada etapa são reutilizados nos 2 anos posteriores a escolha e com a devida reposição."

\subsection{Breve análise do livro didático adotado na escola pesquisada}

Com o que foi dito acima, o livro didático adotado pela escola pesquisada é Matemática Contexto e Aplicações, volume 2, de Luiz Roberto Dante. Nele, o conteúdo de geometria plana e espacial está na unidade 3, capítulos 7, 8, 9 e 10. No início da unidade, o autor mostra uma atividade com origami para se fazer um cubo, como motivação ao tema. No entanto, dentro dos capítulos, não se vê outra atividade prática para se trabalhar com os alunos. Há propostas de muitos exercícios contextualizados, mas nenhum deles envolve alguma atividade prática. No final do livro, mais especificamente, nas páginas de 376 a 385, há algumas indicações de atividades a serem realizadas em sala de aula, mas essas atividades estão apenas no livro entregue ao professor. No livro dos alunos, esta parte foi retirada. Nessa parte adicional inserida no livro do professor, há um retorno ao tema do que deve ser esperado do aluno na atividade do origami, e um retorno de como os exercícios devem ser trabalhados. Incluem-se também atividades complementares para o cálculo da fórmula de Euler observando-se algumas figuras. No entanto, a simples observação de uma representação no plano de um objeto tridimensional, um poliedro por exemplo, não é suficiente para que o estudante possa inferir todas as informações sobre

número de arestas, vértices e faces. É necessário sugerir que os alunos construam alguns desses objetos geométricos indicados com materiais práticos.

O livro traz nas indicações ao professor, ainda, dois textos para serem trabalhados com 
os estudantes: o primeiro relacionado às pirâmides do Egito e o segundo sobre o Planeta Terra. Após isso, o autor propõe a construção de poliedros regulares, que poderia ser usada na mesma aula para confirmar a fórmula de Euler. Assim, fazendo uma síntese do que foi feito no livro, as sugestões se resumem à construção de poliedros e à análise destes. O professor deveria procurar atividades adicionais para trabalhar com os estudantes, o que, na maioria das vezes, não acontece.

\subsection{Saeb}

Para verificar os conhecimentos que os estudantes brasileiros têm ao final de cada etapa da escolaridade, o governo lança mão do Sistema de Avaliação da Educação Básica (Saeb). De acordo com o portal do Inep:

O Sistema de Avaliação da Educação Básica (Saeb), conforme estabelece a Portaria n. ${ }^{\circ}$ 931, de 21 de março de 2005, é composto por dois processos: a Avaliação Nacional da Educação Básica (Aneb) e a Avaliação Nacional do Rendimento Escolar (Anresc).

A Aneb é realizada por amostragem das Redes de Ensino, em cada unidade da Federação e tem foco nas gestões dos sistemas educacionais. Por manter as mesmas características, a Aneb recebe o nome do Saeb em suas divulgações;

A Anresc é mais extensa e detalhada que a Aneb e tem foco em cada unidade escolar. Por seu caráter universal, recebe o nome de "Prova Brasil"em suas divulgações.

(BRASIL, 2015)

Pelo Saeb, o desempenho dos alunos no ensino fundamental é medido em uma escala de proficiência que vai de 0 a 425 pontos, sendo descritas as habilidades que os alunos possuem a partir do nível 125. No nível 125 a 150, eles resolvem problemas de cálculo de área com base na contagem das unidades de uma malha quadriculada e, apoiados em representações gráficas, reconhecem a quarta parte de um todo. Nesse nível 1 da escala, já comparecem alguns conhecimentos de geometria. Somente no nível 4 é que se evidencia a apreensão de outros conhecimentos de geometria, mais especificamente, nesse nível o estudante é capaz de identificar propriedades comuns e diferenças entre poliedros e corpos redondos, relacionando figuras tridimensionais com suas planificações. Isso mostra que o domínio do conhecimento geométrico é de grande dificuldade de aprendizado para os estudantes brasileiros. Um tema simples da área que é identificar figuras geométricas 
somente aparece em um nível no qual também está o reconhecimento da regra de formação de uma sequência numérica. Assim os conhecimentos mais complexos de geometria pelo Saeb são identificar ângulos retos e não retos, calcular diâmetro de circunferências concêntricas e utilizar as propriedades dos polígonos para resolver problemas. Identificar ângulos retos, que, do ponto de vista matemático, é um conhecimento que deveria ser considerado simples nessa etapa da escolaridade, somente está no maior nível da escala de proficiência, ou seja, poucos alunos sabem identificar um ângulo reto.

De acordo com a última prova do Saeb, que foi realizada em 2013, a média nacional em matemática dos estudantes do ensino fundamental, $9^{\circ}$ ano, foi de 251,54, em uma escala de média 250 e desvio-padrão de 50 pontos, o que mostra que a maior parte dos estudantes que terminam o ensino fundamental somente tem os conhecimentos citados do nível 1 e 4 em geometria. No ensino médio, o resultado revela-se muito pior, pois no desempenho médio de 270,15 para essa etapa da escolaridade, a interpretação da escala de proficiência em matemática mostra que os estudantes não têm nenhum conhecimento geométrico novo até esse nível além de identificar propriedades comuns e diferenças entre figuras bidimensionais pelo número de lados e pelos tipos de ângulos e de identificar propriedades comuns e diferenças entre poliedros e corpos redondos, relacionando figuras tridimensionais com suas planificações. (INEP, 2015)

Em uma análise das questões disponibilizadas pelo Instituto Nacional de Estudos e Pesquisas (INEP) como exemplo para a prova aplicada, destacamos as seguintes: 
000

IT_ 023100

Uma caixa d'água tem suas dimensőes indicadas conforme a figura abaixo.

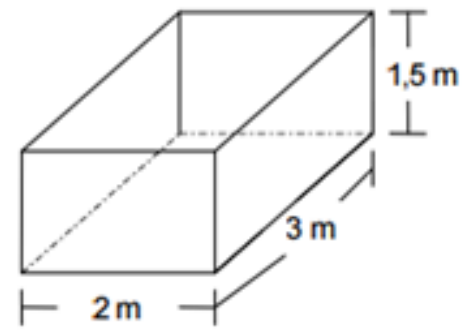

A quantidade de água, em metros cúbicos, que essa caixa pode armazenar é
(A) 6,0 .
(B) 6,5 .
(C) 7,5 .
(D) 9,0 .

Figura 1.1: Exemplo de questão da Prova Brasil. $9^{\circ}$ ensino fundamental (INEP, 2015).

(INEP, 2015)

Conforme a figura abaixo: 
Tabela 1.1: Níveis 11 e 12 de desempenho dos alunos de matemática, (INEP, 2015)

\begin{tabular}{|c|c|}
\hline $\begin{array}{l}\text { Níveis de desempenho dos } \\
\text { alunos em matemática }\end{array}$ & O que os alunos conseguem fazer nesse nível. \\
\hline Nível 11 - 375 a 400 & $\begin{array}{l}\text { - reconhecem expressão algébrica que representa uma } \\
\text { função a partir de uma tabela; - reconhecem figuras } \\
\text { semelhantes mediante o reconhecimento de relações de } \\
\text { proporcionalidade; } \\
\text { - identificam: } \\
\text { - a localização de números racionais na reta numérica; } \\
\text { - propriedades de triângulos pela comparação de medi- } \\
\text { das de lados e ângulos; } \\
\text { - propriedades comuns e diferenças entre figuras bidi- } \\
\text { mensionais e tridimensionais, relacionando-as com as } \\
\text { suas planificações; } \\
\text { - a relação entre representações algébrica e geométrica } \\
\text { de um sistema de equações do } 1^{\circ} \text { grau; } \\
\text { - resolvem problemas: } \\
\text { - envolvendo noções de volume; } \\
\text { - envolvendo porcentagem; } \\
\text { - utilizando propriedades dos polígonos (soma de seus } \\
\text { ângulos internos, número de diagonais, cálculo da me- } \\
\text { dida de cada ângulo interno nos polígonos regulares); } \\
\text { - utilizando relações métricas dos triângulo retângulo; } \\
\text { - interpretando informações apresentadas em tabelas } \\
\text { e/ou gráficos. }\end{array}$ \\
\hline Nível 12 - 400 a 425 & $\begin{array}{l}\text { Além das habilidades demonstradas nos níveis anterio- } \\
\text { res, neste nível os alunos do } 9^{\circ} \text { ano: } \\
\text { - identificam ângulos retos e não-retos; } \\
\text { - identificam a expressão algébrica que representa uma } \\
\text { regularidade observada em sequência de números ou fi- } \\
\text { guras (padrões); } \\
\text { - calculam o diâmetro de circunferências concêntricas; } \\
\text { - resolvem problemas: } \\
\text { - envolvendo equação do } 2^{\circ} \text { grau; } \\
\text {-utilizando propriedades dos polígonos (soma dos ângu- } \\
\text { los, número de diagonais, cálculo da medida de cada } \\
\text { ângulo interno nos polígonos regulares); } \\
\text { - envolvendo variação proporcional, direta ou inversa, } \\
\text { entre grandezas. }\end{array}$ \\
\hline
\end{tabular}




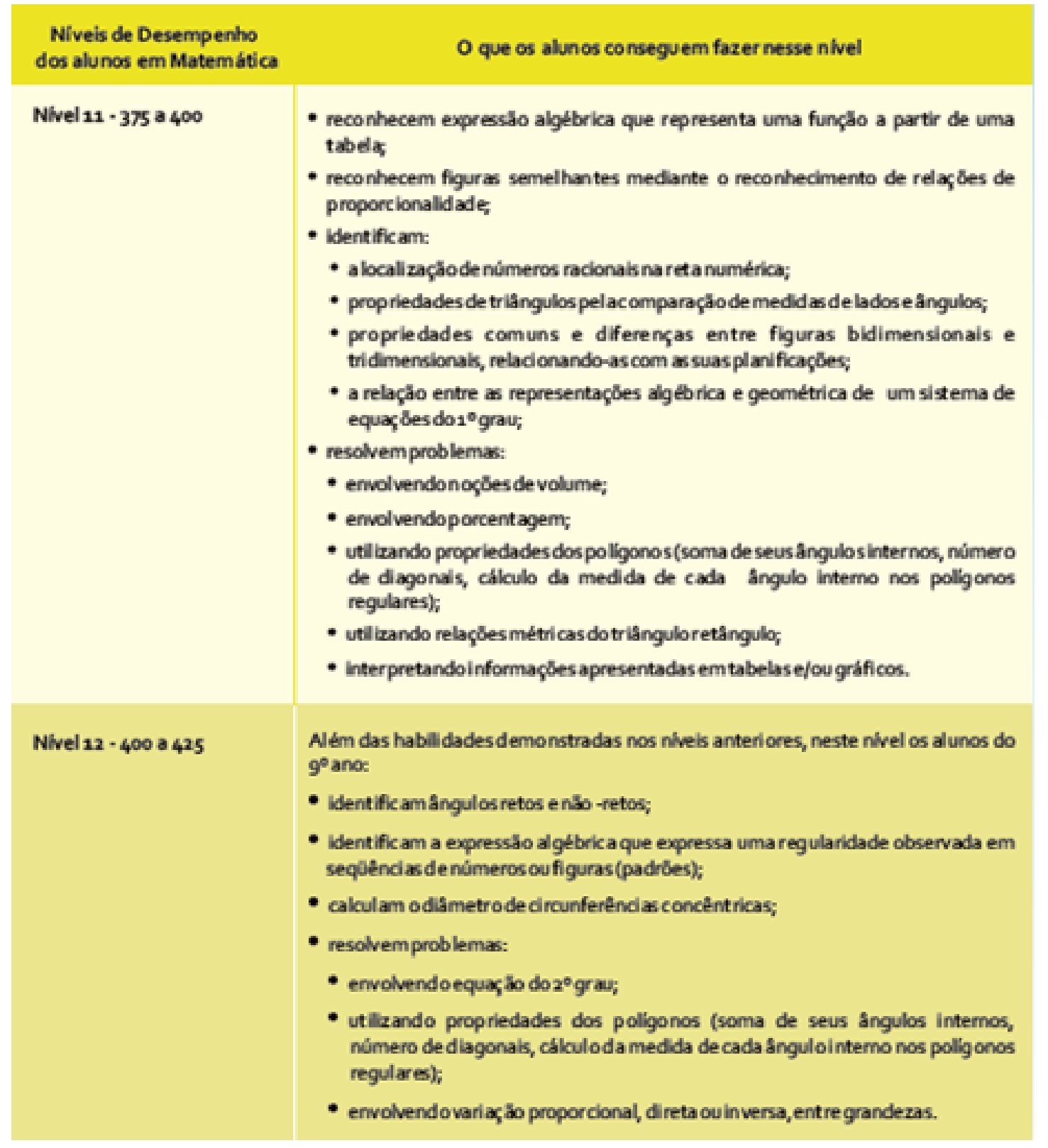

Figura 1.2: Níveis 11 e 12 de desempenho dos alunos de matemática, (INEP, 2015). 
Pelos níveis do Saeb, relacionando-se o nível alcançado pela maioria dos estudantes, que é o nível 4, e a tabela no nível 11 (resolvem problema envolvendo noções de volume), esse item seria um exemplo de um conhecimento não apreendido pela quase totalidade dos alunos, revelando habilidades ou conceitos não adquiridos. No entanto, para se encontrar a solução, seria suficiente multiplicar as dimensões $2 \mathrm{~m}, 3 \mathrm{~m}$ e 1,5 m do paralelepípedo, já que todas estão em metros, obtendo-se como resposta 9 metros cúbicos.

000 IT_020041

Duas pessoas, partindo de um mesmo local, caminham em direções ortogonais. Uma pessoa caminhou 12 metros para o sul, a outra, 5 metros para o leste.

Qual a distância que separa essas duas pessoas?
(A) $7 \mathrm{~m}$.
(B) $13 \mathrm{~m}$.
(C) $17 \mathrm{~m}$.
(D) $60 \mathrm{~m}$.
(E) $119 \mathrm{~m}$.

Figura 1.3: Exemplo 2 de questão da Prova Brasil, (INEP, 2015). 
Tabela 1.2: Nível 9 de desempenho dos alunos de matemática, (INEP, 2015)

\begin{tabular}{|c|c|}
\hline $\begin{array}{l}\text { Níveis de desempenho dos } \\
\text { alunos em matemática }\end{array}$ & O que os alunos conseguem fazer nesse nível. \\
\hline Nível 9 - 325 a 350 & $\begin{array}{l}\text { - calculam a área de um polígono desenhado em malha } \\
\text { quadriculada; } \\
\text { - reconhecem a representação numérica de uma fração a } \\
\text { partir do preenchimento de partes de uma figura. } \\
\text { No } 9^{\circ} \text { ano os alunos também: } \\
\text {-reconhecem círculo/ circunferência, seus elementos e al- } \\
\text { gumas de suas relações ; } \\
\text { - realizam conversão e somas de medidas de compri- } \\
\text { mento; } \\
\text { - identificam a expressão algébrica que expressa uma } \\
\text { regularidade observada em sequência de números ou fi- } \\
\text { guras; } \\
\text { - resolvem problemas utilizando entre diferentes unida- } \\
\text { des de medida; } \\
\text { - resolvem problemas que envolvam equação do } 2^{\circ} \text { grau; } \\
\text { - identificam fração como representação que pode estar } \\
\text { associada a diferentes significados; } \\
\text {-resolvem problemas: } \\
\text { - envolvendo a escrita decimal de cédulas e moedas do } \\
\text { sistema monetário brasileiro, utilizando várias operações } \\
\text { (adição, subtração, multiplicação e divisão); } \\
\text { - utilizando relações métricas do triângulo retângulo; } \\
\text { - reconhecem que as imagens de uma figura construída } \\
\text { por uma transformação homotética são semelhantes, } \\
\text { identificando propriedades e/ou medidas que se modi- } \\
\text { ficam ou não se alteram. }\end{array}$ \\
\hline
\end{tabular}




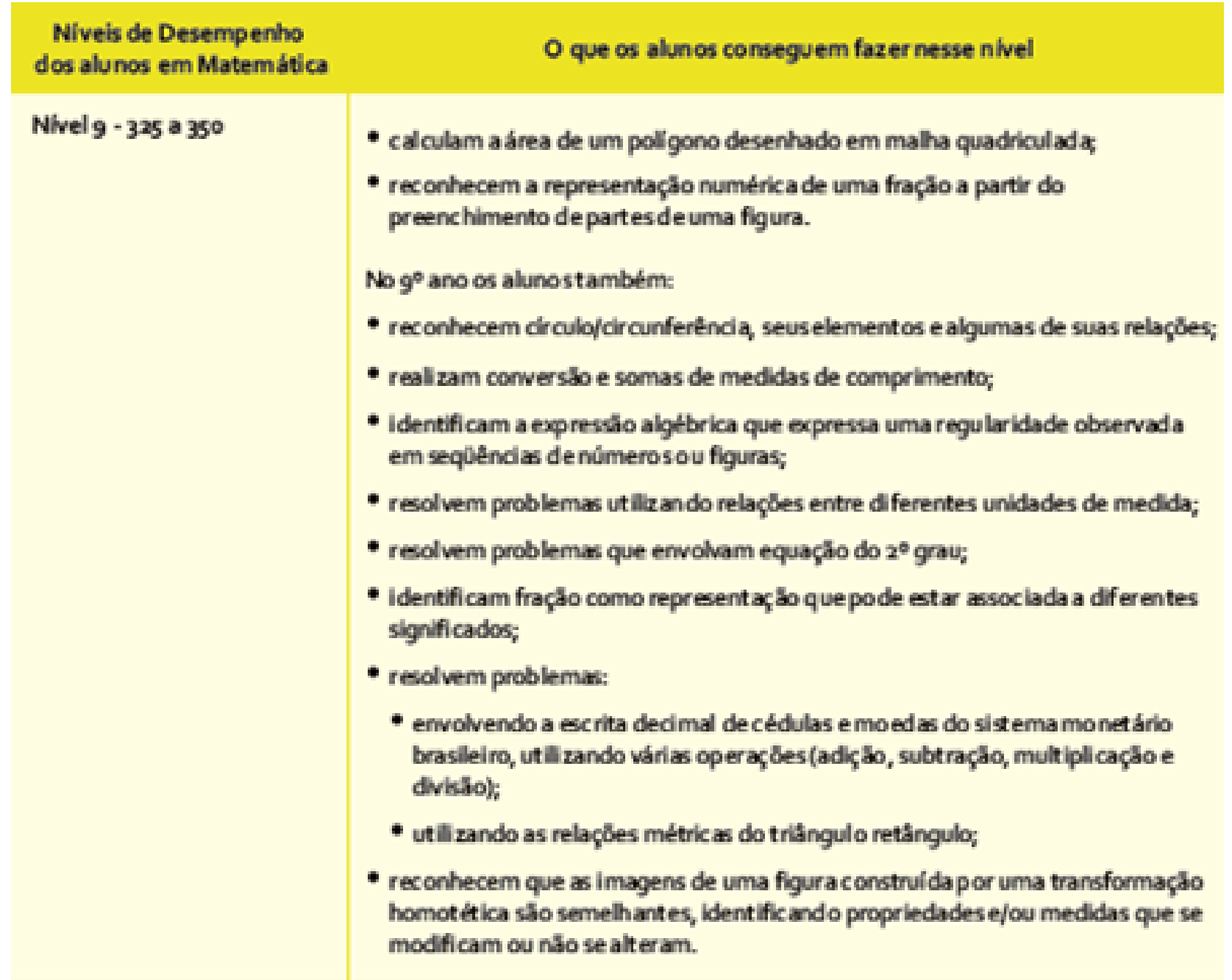

Figura 1.4: Nível 9 de desempenho dos alunos em matemática, (INEP, 2015).

Este é um exemplo de item que os alunos do ensino médio teriam dificuldade de encontrar a resposta, de acordo com os níveis obtidos na prova (por volta de 270,15) e comparando-se com o quadro da escala de rendimento (resolver problemas utilizando relações métricas no triângulo retângulo - Teorema de Pitágoras). Isso induz à conclusão de que os conhecimentos aplicados no ensino médio não são aperfeiçoados o suficiente para resolver problemas em níveis de desempenho elevados.

Nota-se que para solucionar esse problema basta observar que as pessoas caminham em direções perpendiculares (ortogonais), formando um ângulo reto e um triângulo retângulo, no qual 5 metros e 12 metros representam os catetos. Assim, a distância é representada pela hipotenusa desse triângulo retângulo. A resposta via Teorema de Pitágoras é 13 metros.

De acordo com Rabelo (2013), a partir do desempenho nas provas do Saeb, pode 
ser construída a série histórica do percentual de estudantes brasileiros com aprendizado adequado à série em Matemática e Língua Portuguesa. De acordo com a tabela 1, abaixo, apenas 10,3\% dos estudantes que concluíram o ensino médio em 2011 demonstraram ter aprendizado adequado à série em matemática.

Tabela 1.3: Evolução da proporção de alunos com aprendizado adequado à série no Brasil (1999-2011), em \%.

\begin{tabular}{lr|l|l|l|l|l|l|l}
\hline Série/Ano & & 1999 & 2001 & 2003 & 2005 & 2007 & 2009 & 2011 \\
\hline $\begin{array}{l}5^{\circ} \text { ano do ensino } \\
\text { fundamental- } \\
\text { portuguesa. }\end{array}$ & 24,8 & 23,7 & 25,6 & 26,6 & 27,9 & 34,2 & 40,0 \\
\hline $\begin{array}{l}5^{\circ} \text { ano do } \\
\text { fundamental- } \\
\text { tica. }\end{array}$ & $\begin{array}{r}\text { ensino } \\
\text { Matemá- }\end{array}$ & 14,4 & 14,9 & 15,1 & 18,7 & 23,7 & 32,5 & 36,0 \\
\hline $\begin{array}{l}9^{\circ} \text { ano do ensino } \\
\text { fundamental- } \\
\text { portuguesa. }\end{array}$ & 18,6 & 21,8 & 20,1 & 19,5 & 20,5 & 26,2 & 27,0 \\
\hline $\begin{array}{l}9^{\circ} \text { Lingua do ensino } \\
\text { fundamental- } \\
\text { tica. Matemá- }\end{array}$ & 13,2 & 13,4 & 14,7 & 13,0 & 14,3 & 14,7 & 16,9 \\
\hline $\begin{array}{l}3^{\circ} \text { ano do ensino médio- Lín- } \\
\text { gua portuguesa. }\end{array}$ & 27,6 & 25,8 & 26,9 & 22,6 & 24,5 & 28,9 & 29,0 \\
\hline $\begin{array}{l}3^{\circ} \text { ano do ensino médio- Ma- } \\
\text { temática. }\end{array}$ & 11,9 & 11,6 & 12,8 & 10,9 & 9,8 & 11,0 & 10,3 \\
\hline
\end{tabular}

(RABELO, 2013, p.39)

Para se confirmar o que foi dito acima, apresenta-se o exemplo de um item a seguir, aplicado para avaliar a capacidade de o estudante resolver problema envolvendo o cálculo de perímetro de figuras planas $\left(9^{\circ}\right.$ ano).

Exemplo 1: no polígono abaixo, todos os lados opostos são paralelos. 


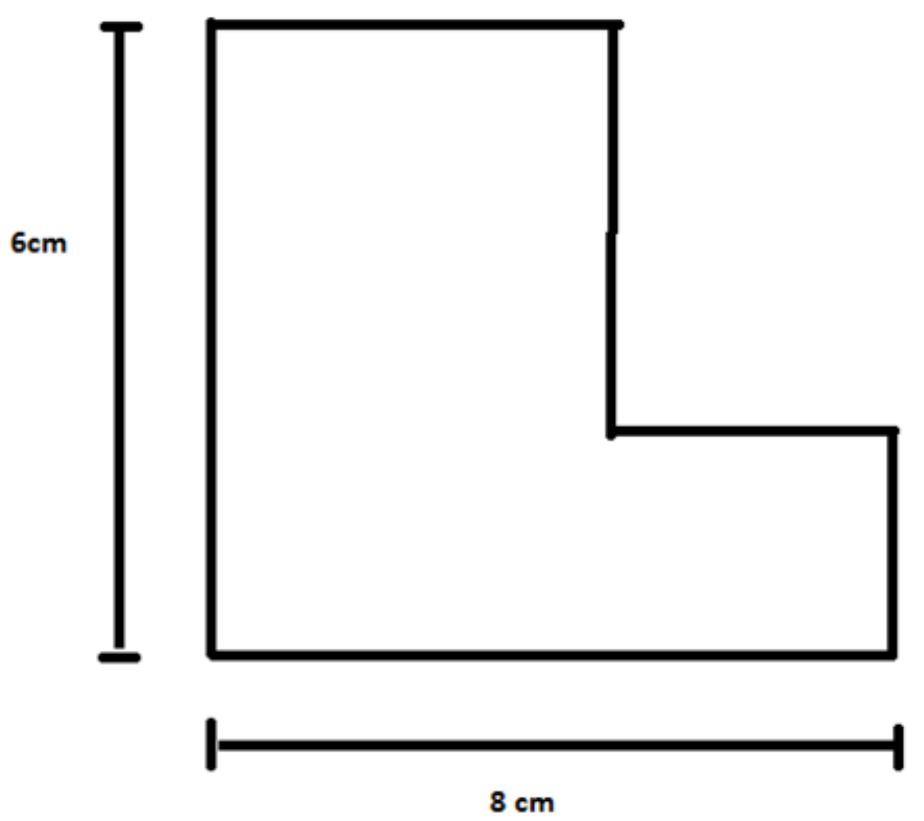

Figura 1.5: Figura de um polígono refeita a partir de uma questão de: http://simposio.profmat-sbm.org.br/docs/Mesa-redonda-MauroRabelo.pdf.

Qual o perímetro deste polígono?
(A) $14 \mathrm{~cm}$.
(B) $28 \mathrm{~cm}$.
(C) $36 \mathrm{~cm}$.
(D) $48 \mathrm{~cm}$.

A alternativa (A), que é uma resposta errada, atraiu 50\% dos alunos; é simplesmente a soma de dois lados cujas dimensões aparecem na figura.

Tabela 1.4: índices de respostas ao item do exemplo 1

\begin{tabular}{l|l|l|l|l|l|l|l|l}
\hline Item & BL & OB & GAB & DIF & DISCR & ABAI & ACIM & BISSE \\
\hline 25 & 2 & 12 & B & 0,23 & 0,39 & 0,10 & 0,50 & 0,53 \\
\hline
\end{tabular}

(fonte: http://simposio.profmat-sbm.org.br/docs/Mesa-redonda-MauroRabelo.pdf)

Isso mostra na realidade que a maioria dos estudantes não consegue resolver um problema simples sobre perímetro, demonstrando falta de apreensão de uma noção básica do campo matemático das grandezas e medidas. Assim, o estudante teria que observar que as medidas opostas mesmo repartidas em duas são iguais à duas dadas. Logo, o perímetro é 28 centímetros. 
O problema seguinte foi aplicado na Prova Brasil em 2008, também sobre perímetros, mas aplicado aos alunos do terceiro ano do ensino médio.

Exemplo 2: uma praça quadrada, que possui o perímetro de 24 metros, tem uma árvore de cada vértice e fora dela. Deseja-se aumentar a área da praça, alterando-se sua forma e mantendo se as árvores externas a ela, conforme ilustra a figura. 


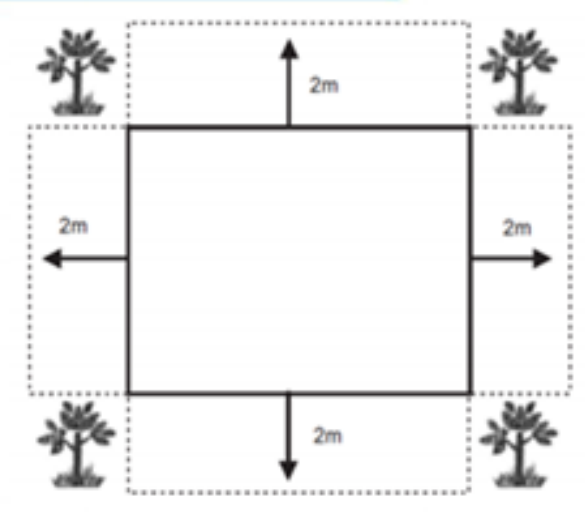

Figura 1.6: Imagem para resolução do exemplo 2.

(RABELO, 2013, p.31)

O novo perímetro da praça é
(A) $24 \mathrm{~m}$.
(B) $32 \mathrm{~m}$.
(C) $36 \mathrm{~m}$.
(D) $40 \mathrm{~m}$.
(E) $64 \mathrm{~m}$.

Tabela 1.5: Percentual de respostas ao exemplo 2

\begin{tabular}{l|l|l|l|l}
\multicolumn{5}{c}{ Percentual de respostas as alternativas } \\
\hline $\mathrm{A}$ & $\mathrm{B}$ & $\mathrm{C}$ & $\mathrm{D}$ & $\mathrm{E}$ \\
\hline $10 \%$ & $44 \%$ & $13 \%$ & $21 \%$ & $8 \%$ \\
\hline
\end{tabular}

Para se obter a resposta correta deveria marcar a alternativa D.

(RABELO, 2013, p.31)

É um problema simples que apenas exige do aluno observar que se somam oito partes de 2 metros à medida antiga, o que pode ser resolvido com uma observação simples ao desenho. Como apenas $21 \%$ conseguiram achar a resposta correta, isso revela que a maioria não consegue resolver esse problema, corroborando com os dados obtidos que somente cerca de $10 \%$ dos estudantes brasileiros terminam o ensino médio com o aprendizado adequado à série. Além disso, vê-se que a geometria tem-se mostrado uma das maiores dificuldades dos alunos. 


\subsection{ENEM}

Outra forma de avaliar os alunos na qual se pode observar o nível dos conhecimentos adquiridos por eles é por intermédio do Exame Nacional do Ensino Médio, o ENEM. A Matriz que dá a fundamentação teórica para elaboração dos itens do Exame apresenta, entre as competências para a área de matemática, avaliar os conhecimentos em geometria e grandezas e medidas na seguinte perspectiva:

Competência de área 2 - Utilizar o conhecimento geométrico para realizar a leitura e a representação da realidade e agir sobre ela.

H6 - Interpretar a localização e a movimentação de pessoas/objetos no espaço tridimensional e sua representação no espaço bidimensional.

H7 - Identificar características de figuras planas ou espaciais.

H8 - Resolver situação-problema que envolva conhecimentos geométricos de espaço e forma.

H9 - Utilizar conhecimentos geométricos de espaço e forma na seleção de argumentos propostos como solução de problemas do cotidiano.

Competência de área 3 - Construir noções de grandezas e medidas para a compreensão da realidade e a solução de problemas do cotidiano.

H10 - Identificar relações entre grandezas e unidades de medida.

H11 - Utilizar a noção de escalas na leitura de representação de situação do cotidiano.

H12 - Resolver situação-problema que envolva medidas de grandezas.

H13 - Avaliar o resultado de uma medição na construção de um argumento consistente.

H14 - Avaliar proposta de intervenção na realidade utilizando conhecimentos geométricos relacionados a grandezas e medidas.

(RABELO, 2013, p.60-61)

No ENEM, as habilidades avaliadas costumam ser mais complexas do que os descritores avaliados nos itens do Saeb. Além disso, a contextualização no ENEM traz outros complicadores para a avaliação. Isso pode ser exemplificado pela questão 142 do ENEM 2014 . 
Exemplo 3:

\section{QUESTÃO 142}

Na alimentação de gado de corte, o processo de cortar a forragem, colocá-la no solo, compactá-la e protegê-la com uma vedaçăo denomina-se silagem. Os silos mais comuns sâo os horizontais, cuja forma é a de um prisma reto trapezoidal, conforme mostrado na figura.
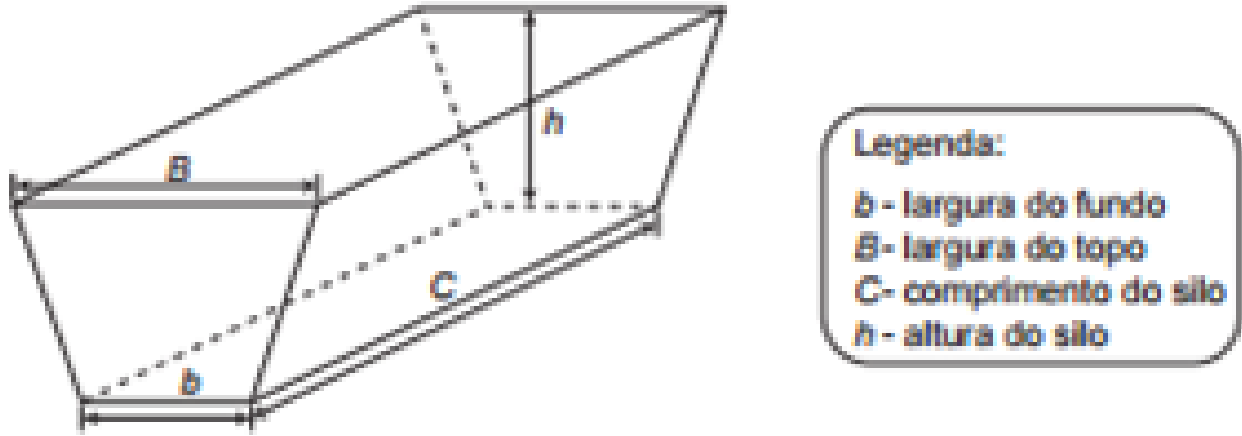

Considere um silo de $2 \mathrm{~m}$ de altura, $6 \mathrm{~m}$ de largura de topo e $20 \mathrm{~m}$ de comprimento. Para cada metro de altura do silo, a largura do topo tem $0,5 \mathrm{~m}$ a mais do que a largura do fundo. Após a silagem, 1 tonelada de forragem ocupa $2 \mathrm{~m}^{3}$ desse tipo de silo.

EMERAPA. Gado de corte. Diporivel en wwonpge.enbrapa.br. Marsiso en 1 spo. 2012 (adstado)

Após a silagem, a quantidade máxima de forragem que cabe no silo, em toneladas, é
(4) 110 .
B 125 .
C 130 .
(D) 220 .
(9) 260 .

Figura 1.7: Questão 142 - ENEM 2014. 
(INEP, ENEM 2014)

Para a solução desse item, o aluno deve observar que a figura é um prisma, cuja base é um trapézio, o qual, pelos dados do problema, tem base maior igual a 6 metros, base menor igual a 5 metros e altura de 2 metros. Logo, a área da base desse prisma é 11 metros quadrados. Assim, considerando a altura do prisma igual a 20 metros, o estudante deveria concluir que o volume é 220 metros cúbicos. Fazendo se a conversão desejada de 1 tonelada correspondente a 2 metros cúbicos, a resposta 110 é encontrada fazendo a regra de três simples: 1 tonelada está para 2 metros cúbicos, assim como "X"(incógnita que será encontrada) está para 220 metros cúbicos. Sendo bem mais complexa que as do Saeb, provavelmente um aluno teria uma dificuldade maior em achar a solução para essa questão do que o volume do paralelepípedo exemplificado anteriormente. Além do mais, um aluno poderia calcular o volume adequadamente, mas se esquecer de fazer a conversão, chegando a outra resposta.

\subsection{Dificuldades no ensino de geometria}

O ensino da geometria tem como dificuldade adicional a falta de interesse dos alunos, considerando que, em muitos livros, esse conteúdo é desenvolvido por meio de exercícios de fixação, sem a contextualização adequada. Há também um trabalho a ser feito com os professores, conforme se infere das observações de Pavavello, quando diz:

O enfoque de trabalhar geometria sob o enfoque das transformações, assunto não dominado pela grande maioria dos professores secundários, acaba por fazer com que muitos deixem de ensinar geometria sobre qualquer abordagem, passando a trabalhar predominantemente a álgebra.

(PAVAVELLO, 1989, p.164-165)

Assim, quando se evidencia entre os objetivos da BNC, "utilizar o conceito de vetor para associar duas figuras congruentes à composição de transformações no plano (reflexão, translação e rotação), com ou sem o uso de tecnologias digitais", isso pode significar a necessidade futura de se fazer um trabalho adicional com os docentes da área de matemática.

Se formos analisar nossa pedagogia ou didática, veremos que quase a totalidade absoluta dos métodos usados ainda são baseados na matriz teórica, do estímulo-resposta. Os professores fazem as coisas, dão exemplos, e os alunos reproduzem e repetem o que lhes é pedido. 
(GUARESCHI, 2005. p.103)

Acrescenta-se a isso o fato de muitos professores não darem a devida atenção ao tema, trabalhando a geometria de forma aligeirada, descontextualizada das aplicações, sem procurarem motivar o interesse dos estudantes pela área e pelo saber.

O uso de tecnologias, materiais específicos e recursos didáticos diferentes do livro didático adotado na escola é raro de se ver, e isso estimularia o conhecimento e o saber.

O conhecimento é o gerador do saber, que vai ser decisivo para a ação. Por conseguinte, é no comportamento, na prática, no fazer que se avalia, redefine e reconstrói o conhecimento. A consciência é o impulsionador da ação do homem em direção ao saber/fazendo e fazer/sabendo, isto é, à sobrevivência e à transcendência. O processo de aquisição do conhecimento é, portanto, essa relação dialética saber/fazer, impulsionado pela consciência, que se realiza em várias dimensões.

(D'AMBROSIO, 2005, p.109)

O saber é algo que o estudante irá carregar por toda sua vida, é uma experiência de aquisição de conhecimento e de desenvolvimento de habilidades cognitivas. Segundo Guaresqui (2005.p.106): "saber, no seu sentido original, significa sentir o gosto, perceber o gosto duma coisa. Isso vem mostrar que o saber é uma experiência. E toda experiência é única, singular, pessoal e irrepetível."

O professor precisa ter o perfil de pesquisador e procurar constantemente formas alternativas para ensinar, criando suas próprias atividades, sempre conectado com o objetivo primordial de seu trabalho, que é o de favorecer a aprendizagem dos estudantes.

Infelizmente, ele encontra barreiras frequentes, já que muitas escolas não oferecem a estrutura adequada para que ele realize as atividades, especialmente se não forem muito inovadoras, demandando outras concepções de espaços, diferentes da sala de aula tradicional. Pavanello separa as escolas brasileiras em duas categorias, segundo o ensino da geometria:

A tradicional dualidade do ensino brasileiro até que poderia em termos do ensino de matemática, ser colocada como: "a escola que ensina geometria"(escola particular) e "escola onde não se ensina geometria"(escola para o povo). 
O aprimoramento contínuo do professor é muito importante, pois ele exerce o papel de mediador do conhecimento. O professor deve ser incentivado a buscar novos conhecimentos, em especial no que diz respeito às práticas didáticas, a alternativas para o ensino e a aprendizagem dos estudantes. Em seu livro, 10 novas competências para se ensinar, Perrenoud (2000. p.14) destaca 10 grandes famílias de competências que o professor deve ter, que incluem:

- Organizar e dirigir situações de aprendizagem;

- Administrar a progressão da aprendizagem;

- Envolver os alunos em sua aprendizagem e em seu trabalho;

- Utilizar tecnologias;

- Administrar sua formação continuada.

(PERRENOUD, 2000. p. 14)

Se isso não ocorrer, ele apenas vai reproduzir o que está proposto e "congelado"nos livros didáticos, ou imitar algum de seus antigos professores, sem o preparo suficiente para fazer as críticas necessárias. O conhecimento pleno deve ter situações novas, contextualizadas e inovadoras, para, assim, poder fazer conexões com a realidade vivenciada. A respeito disso, Pavanello afirma que:

A constatação dessa situação e as dificuldades encontradas pelos professores de vários cursos (não só de matemática, ou de disciplinas afins) em trabalhar com alunos, cujo conhecimento é (quase) nulo, mesmo a nível de representação, tem tornado esse assunto polêmico, gerando necessidade de preocupação quanto a necessidade desse ensino - e de como desenvolvê-lo.

(PAVANELLO, 1989, p.166)

O tradicional deve ser mudado, o modelo não dialógico denominado "transmissãorecepção", em que os alunos escutam passivamente o professor. Na matemática, isso se reflete na apresentação de conteúdos de forma oral, inserção de alguns exemplos e proposta de exercícios de fixação para os alunos, o que, para muitos educadores, é ineficaz. Isso torna o aluno um reprodutor de apenas algumas ideias e procedimentos mecânicos e rotineiros, sem saber aplicar em contextos. Deve-se incentivar os alunos a conhecer novas condições, escolher problemas que possibilitem interações, conceitos, procedimentos que 
visem ao aperfeiçoamento e ao alcance dos objetivos que se propõem atingir. O professor deve ser o facilitador do aperfeiçoamento das habilidades cognitivas, respeitando o ritmo de cada aluno, incentivando a cooperação entre os colegas que aprenderam com maior facilidade com aqueles que têm maior dificuldade. Para isso, deve reorganizar o ambiente de estudo e propor atividades inovadoras. Isso faz com que os alunos desenvolvam também habilidades afetivas e de inserção social, motivando também o gosto pelo estudo da matemática.

Segundo Guareschi (2005. p.110), o verdadeiro educador "é aquele que sabe fazer a pergunta, colocando o aluno em contradição, obrigando-o, assim, a solucionar ele mesmo essa contradição e colocando-o num processo de caminhada autônoma, independente."

O termo motivar, pelo dicionário Michaelis de língua portuguesa, significa:

1.Ato de motivar. 2. Exposição de motivos. 3.Psicol. Espécie de energia psicológica ou tensão que põe em movimento o organismo humano, determinando um dado comportamento. 4.Sociol. Processo de iniciação de uma ação consciente e voluntária.

A partir dessa definição, vemos que é preciso motivar o aluno, pois falta a ele algumas visões. Muitos professores já ouviram perguntas em sala de aula tais como:

- Pra que isso serve?

- Onde vou usar isso?

Não é simples motivar, pois a motivação envolve fatores emocionais, biológicos e sociais, entre outros. Desenvolver esses fatores requer conhecimento social, como, por exemplo, trabalhar a afetividade. Pode-se tentar motivar o aluno ao aprendizado de matemática propondo-se atividades (situações-problema) contextualizadas e diferenciadas. E para isso os professores devem estar preparados para aplicar, criar e incentivar os discentes. Para Martini e Prette, é preciso que os processos de capacitação de professores:

Incluam, em seus programas, as dimensões afetiva e socioemocional, uma vez que estes precisam estar atentos e preparados para lidar com essas dimensões em si mesmo e em seus alunos, assim o professor deve saber lidar com a afetividade. Aprender e ensinar os alunos a distinguir as diferentes emoções e sentimentos que experimentam, a identificá-los e reconhecê-los em si mesmos e nos outros e a resolver conflitos interpessoais é tarefa também do professor e da escola e não apenas da família.

(MARTINI E PRETTE, 2005, p. 365)

Paiva e Boruchovith acrescentam que: 
Conclui-se que existem múltiplas formas e caminhos de se promover uma motivação positiva nos alunos em contexto de aprendizagem. É fundamental que esse conhecimento seja traduzido em práticas pedagógicas que propiciem a motivação do aluno. É importante reconhecer, por outro lado, que nem sempre os professores estão preparados para isso e esse conhecimento pode e deve ser utilizado por psicólogos e educadores na capacitação desses professores, em busca de um contexto pedagógico mais favorável ao sucesso escolar.

(PAIVA E BORUCHOVITH 2010, p. 388)

As situações-problema devem ter a proposta de promover novos conhecimentos além das habilidades já citadas. Nesse sentido, Perrenoud (2000 p.31) diz que:"Uma verdadeira situação-problema obriga a transpor um obstáculo graças a uma aprendizagem inédita, quer se trate de uma simples transferência, de uma generalização ou uma construção de um conhecimento inteiramente novo". O que se espera quando se resolve um problema é que o aluno tenha uma ou mais soluções ou procedimentos de resolução, compare os resultados e mostre que tenha sentido para assim validar o que foi realizado. Em muitos exames realizados, comprova-se que os alunos não têm a compreensão correta de como se resolve um problema.

Ao relacionar ideias matemáticas entre si, podem reconhecer princípios gerais, como proporcionalidade, igualdade, composição e inclusão e perceber que processos como o estabelecimento de analogias, indução e dedução estão presentes tanto no trabalho com números e operações como em espaço, forma e medidas.

(PCN - livro 3)

A partir dessa análise dos itens e das dificuldades do ensino-aprendizagem em matemática, os conhecimentos em geometria devem ser aprofundados, tendo um pouco de história da geometria, alguns conceitos e definições a serem desenvolvidos e aprofundados como a base para resolução de problemas, a ser citado no próximo capítulo. 


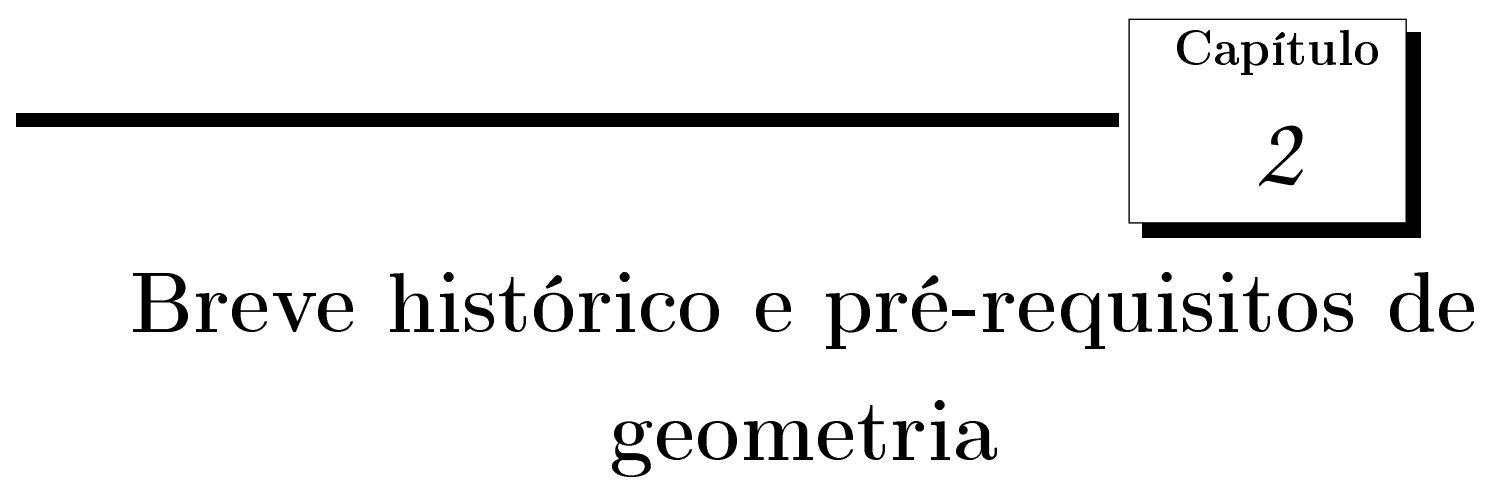

Neste capítulo serão abordadas as definições e algumas demonstrações como prérequisito ao próximo capítulo. E, também, uma breve história para poder introduzir o conteúdo, inclusive com os alunos.

\subsection{Breve história da geometria}

A palavra geometria deriva do grego geo, que significa terra e metria (metrein), cujo significado é medir. Em tempos remotos, a geometria era tratada como uma ciência empírica, na qual usavam-se regras para calcular resultados aproximados, por meio de experimentação, observação de analogias e intuição. Segundo Greennberg (1994, p.6) "em resumo, era um assunto empírico no qual respostas aproximadas eram normalmente suficientes para propósitos práticos."

- Os babilônios de 2000 a 1600 antes de Cristo consideravam o valor do comprimento da circunferência três vezes o valor do diâmetro, e já tinham conhecimento de que em um triângulo retângulo a soma dos quadrados dos catetos é o valor da hipotenusa ao quadrado.

- Os egípcios de 1800 antes de Cristo, de acordo com o papiro de Rhind, utilizavam para $\pi$ o valor aproximado de

$$
\left(\frac{16}{9}\right)^{2} \approx 3,1604
$$


- Os egípcios encontraram a fórmula correta para se determinar o volume de um tronco de pirâmide de base quadrada.

- Os babilônios conheciam o teorema de Pitágoras.

(GREENNBERG 1994, p. 6-7)

Foi com os gregos que a geometria começou a se estabelecer como dedutiva, mais especificamente com Tales de Mileto. Eles juntaram o conhecimento para aplicá-lo na matemática, navegação, astronomia, construções, entre outros. O livro VII dos Elementos de Euclides é o texto da teoria dos números ensinado na escola Pitagórica.

-A sistematização começou com Tales e continuou durante os dois séculos seguintes com Pitágoras e seus discípulos. Pitágoras era respeitado por seus contemporâneos como um profeta religioso... Na música, Pitágoras calculou a razão correta dos intervalos harmônicos.

(GREENNBERG 1994, p. 7)

De acordo com Greennberg (1994, p. 8) "a sistematização de geometria plana pela escola Pitagórica ocorreu em torno de 400 a.C. nos livro Elementos do matemático Hipócrates."Isso ocupa a maior parte dos livros I ao IX dos Elementos de Euclides. Já Eudoxus, que não era da escola Pitagórica, desenvolveu uma teoria das proporções que era válida também para os números irracionais, e foi incluída no livro $\mathrm{V}$ dos Elementos de Euclides.

De acordo com Greennberg (1994, p. 9), aproximadamente no ano 300 antes de Cristo, Euclides, matemático grego de Alexandria, escreveu o volume 1 da coleção Elementos, na qual foram introduzidas 23 definições entre as quais ponto, reta, círculo e retas paralelas, os seguintes cinco axiomas:

1. coisas iguais a uma mesma coisa são também iguais;

2. se iguais são adicionados a iguais, os totais obtidos são iguais;

3. se iguais são subtraídos de iguais, os totais obtidos são iguais;

4. coisas que coincidem uma com as outras são iguais;

5. o todo é maior que uma de suas partes. 
Assim Euclides construiu axiomaticamente a geometria plana. Com apenas cinco postulados, ele foi capaz de deduzir 465 proposições. Os postulados seguem abaixo:

Postulado 1. Pode-se traçar uma única reta ligando dois pontos.

Postulado 2. Pode-se continuar de uma única maneira qualquer reta finita continuamente em uma reta.

Postulado 3. Pode-se traçar um círculo com qualquer centro e qualquer raio.

Postulado 4. Todos os ângulos retos são iguais.

Postulado 5. Sejam duas retas $m$ e $n$ cortadas por uma terceira t. Se a soma dos ângulos é menor que 180 graus, então m e n não são paralelas, e se intersectam do lado dos ângulos cuja soma é menor que 180 graus.

Os Elementos de Euclides não contêm aplicações práticas da geometria, pois o objetivo era realmente o da sistematização do ponto de vista lógico proposicional.

O quinto postulado de Euclides foi um dilema por muito tempo. Proclo (410-485 d.C) citou um exemplo da hipérbole que se aproxima de sua assíntota tanto quanto queira sem encontrá-la, o que mostrou o oposto do quinto postulado e assim começaram as tentativas de demonstrá-lo.

Uma importante tentativa de provar o postulado das paralelas foi do matemático inglês John Wallis (1616-1704), segundo sua tentativa ele criou um novo postulado.

Postulado 6 (Wallis). São dados qualquer triângulo ABC e qualquer segmento DE. Existe um triângulo DEF (tendo DE como um dos seus lados) que é semelhante ao triângulo $A B C$.

A partir deste postulado, Wallis provou o postulado das paralelas usando também a geometria neutral (geometria sem o uso do postulado das paralelas).

Outro trabalho importante foi o do padre jesuíta Girolamo Saccheri (1667-1773). Ele publicou o livro "Euclides Livre de Todas as Falhas", que foi descoberto mais de século depois. Segundo Grennberg (1994, p. 155) "A ideia de Saccheri foi usar o argumento de redução ao absurdo. Ele assumiu a negação do postulado das paralelas e tentou chegar a uma contradição."

Em 1868, o matemático italiano Beltrami mostrou que não é possível demonstrar o postulado das paralelas, assim o que foi feito é que a geometria não-Euclidiana é tão válida quanto à Euclidiana.

As descobertas das geometrias não-Euclidianas se iniciaram no século XIX. János Bolyai publicou suas descobertas em 26 páginas no apêndice do livro O Tentamen de 1831 
de autoria de seu pai, Wolfgang Bolyai. Wolfgang mandou uma cópia de seu livro para Gauss, considerado o maior matemático da época. Gauss também estudava a geometria não-Euclidiana, aos doze anos já olhava com desconfiança sobre a geometria Euclidiana, mas era receoso em publicar seus trabalhos, e assim manteve contato sobre o assunto com matemáticos da época. Também manteve grande interesse na geometria diferencial, publicando vários artigos sobre o assunto.

János tinha 13 anos quando aprendeu o cálculo diferencial e integral. Seu pai escreveu para Gauss implorando que aceitasse o jovem prodígio em sua casa como aprendiz matemático. Gauss nunca respondeu a esse pedido.

(GREENNBERG 1994, p.178)

O primeiro a publicar um texto sobre a geometria não-Euclidiana foi o matemático russo Nikolai Ivanovitch Lobachevsky em 1829. Ele a chamou de "geometria imaginária", tendo sido desenvolvida de uma forma bem completa em seus trabalhos.

Outro ator neste drama histórico veio desviar os holofotes de J. Bolyai e Gauss: o matemático russo Nikolai Ivanovitch Lobachevsky (1792-1856). Ele foi o primeiro a publicar um texto sobre geometria não-eucliciana (1829). Seu trabalho atraiu pouca atenção, principalmente porque foi publicado em russo e os russos que leram fizeram severas críticas. Em 1840 ele publicou um tratado alemão que chamou a atenção de Gauss.

(GREENNBERG 1994, p.183-184)

\subsection{Geometria Euclidiana}

Para o estudo da geometria, deve-se primeiro acrescentar termos, conceitos por meio de definição, antes de se fazer a transição do plano para o espaço. A ampliação desses conceitos para o espaço tem sido uma dificuldade, já que as figuras planas podem ser vistas desenhando-as em uma folha de papel. Já na geometria espacial, a visão do aluno nem sempre acompanha o desenho ou ele não consegue observar com exemplos que não estão em sua realidade. No capítulo seguinte, há algumas atividades que envolvem o trabalho com a geometria plana e espacial. 


\subsubsection{Noções primitivas}

Ponto, reta e plano serão adotados com o conhecimento intuitivo, decorrentes da experiência e observação.

Os pontos serão escritos com letras maiúsculas latinas: A, B, C, ... Na figura abaixo está representado o ponto $\mathrm{P}$.

$\bullet$

Figura 2.1: Ponto P.

As retas são representadas com letras minúsculas: a, b, c, ... Assim a representação da reta r está ilustrada da seguinte forma:

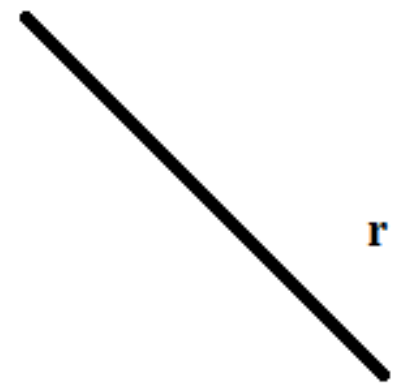

Figura 2.2: Reta R.

Já os planos são representados por letras gregas minúsculas: $\alpha, \beta, \gamma, \ldots$ 


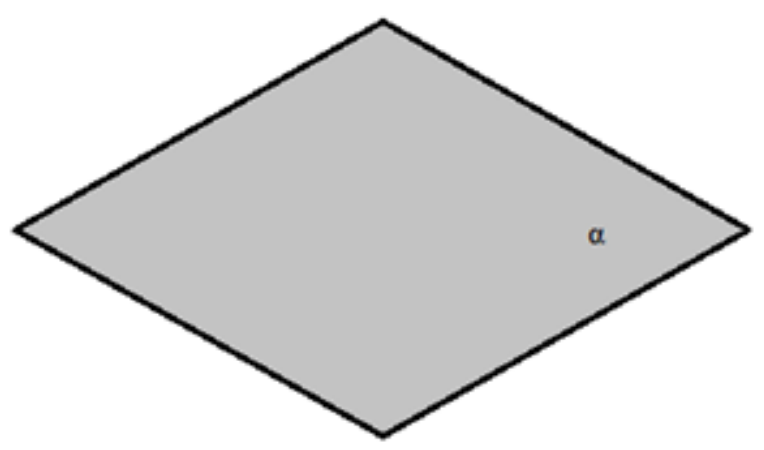

Figura 2.3: Plano $\alpha$.

Observação: vale destacar aqui que tanto a reta quanto o plano são infinitos.

\subsubsection{Proposições e postulados}

As proposições, que são propriedades ou afirmações, são aceitas mediante demonstrações, os postulados são aceitos sem demonstrações. Assim serão estabelecidos alguns postulados.

Postulado 1. Em uma reta, bem como fora dela, existem infinitos pontos. E em um plano há infinitos pontos.

Observação: Postulado 1, também chamado de postulado da existência, quer dizer que existem tantos pontos quanto "quisermos".

Postulado 2. Dois pontos determinam uma única reta que passa por eles.

Postulado 3. Três pontos não colineares do espaço determinam um único plano que passa por eles.

Postulado 4. Se uma reta contém dois pontos distintos em um plano, então essa reta está contida no plano.

Esses quatro postulados serão estabelecidos para as demonstrações de propriedades e teoremas.

Teorema 2.2.1. Existe um único plano que contém uma reta e um ponto não pertencente a ela.

Demonstração. Seja um ponto P não pertencente a uma reta r. E sejam dois pontos Q e $\mathrm{R}$ pertencentes a r. Pode-se afirmar que os pontos $\mathrm{P}, \mathrm{Q}$ e R não são colineares, logo, pelo 
Postulado 3, esses pontos determinam um plano $\alpha$, como este plano é único por conter P, Q e R, logo ele é único por conter P e r.

Definição (retas concorrentes). Duas retas são concorrentes se, e somente se, elas têm um ponto em comum.

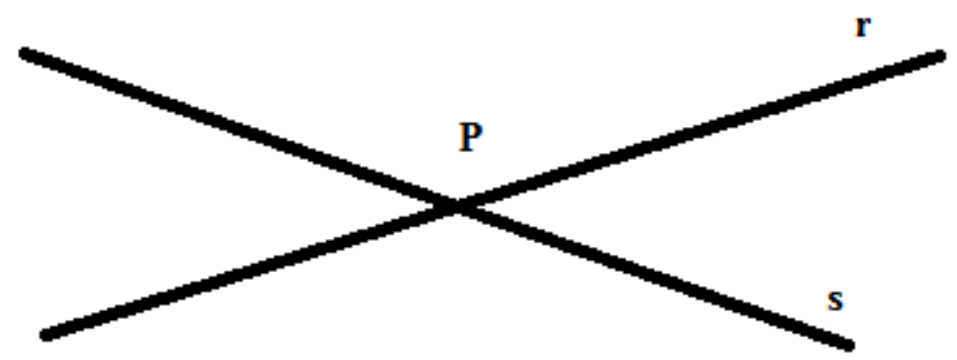

retas $\mathbf{r e s}$

concorrentes pelo

ponto $P$

Figura 2.4: Retas concorrentes.

Pelo Postulado 2, se duas retas tiverem dois pontos comuns, elas serão a mesma reta. $\mathrm{E}$, como consequência do teorema 1 , considere duas retas $\mathrm{r}$ e s e um ponto $\mathrm{P}$ comum a elas, um ponto $\mathrm{S}$ que pertence a $\mathrm{s}$ e um ponto $\mathrm{R}$ que pertence a $\mathrm{r}$. Logo duas retas concorrentes determinam um plano.

Definição (retas reversas). Duas retas que não tenham pontos em comum e que não estejam no mesmo plano são chamadas retas reversas. 


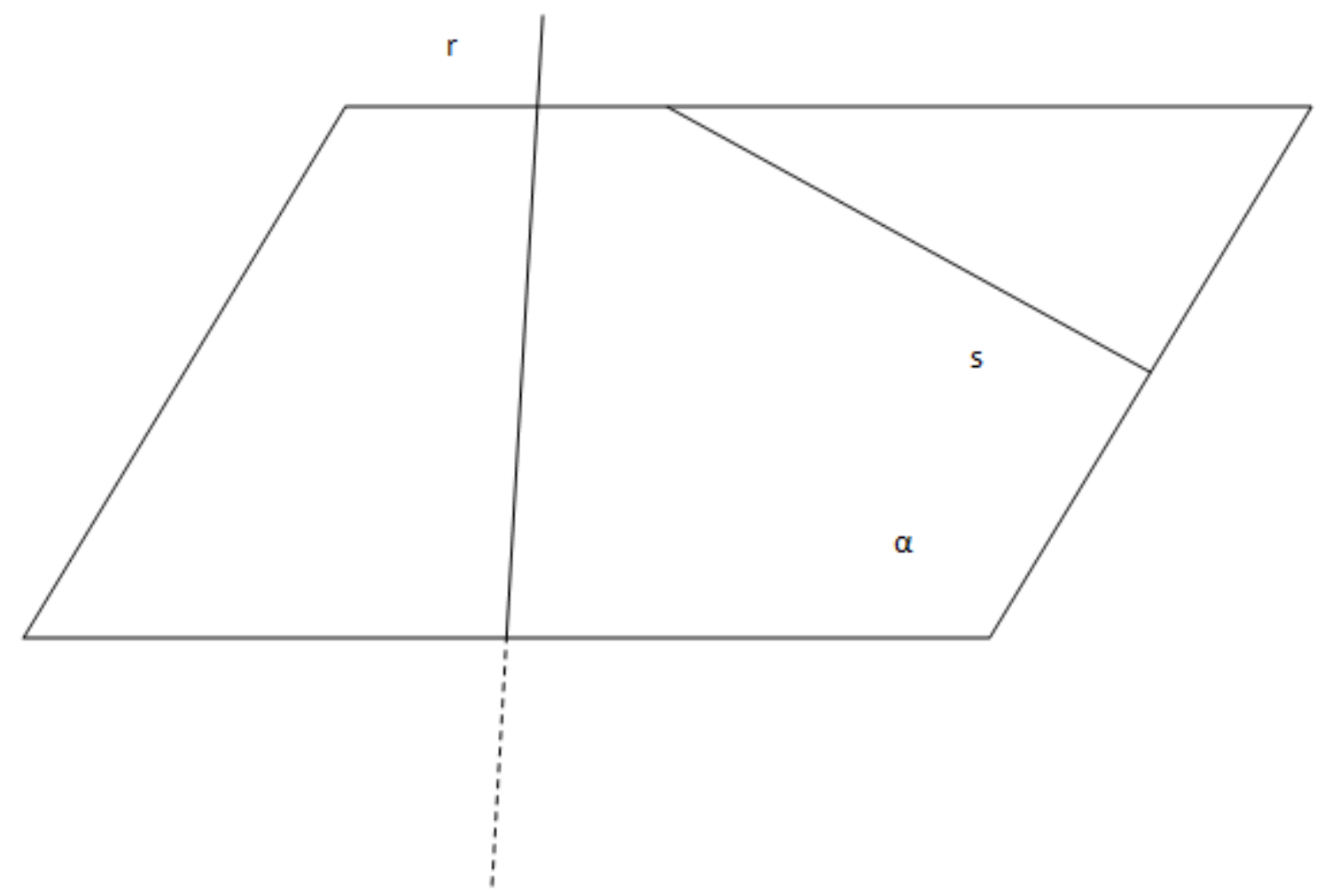

Figura 2.5: Retas reversas.

Definição (retas paralelas). Duas retas são paralelas quando estão no mesmo plano e não têm pontos em comum. 


\begin{tabular}{l}
\hline \\
\hline
\end{tabular}

Figura 2.6: Retas paralelas.

Estas três definições determinam as posições entre as retas.

Observações:

1. dados dois pontos $\mathrm{A}$ e $\mathrm{B}$, a reunião dos pontos entre eles na reta em que eles pertencem é chamado de segmento de reta;

2. dados dois pontos distintos $\mathrm{A}$ e $\mathrm{B}$, a reunião do segmento de reta $\mathrm{AB}$ com o conjunto de pontos $\mathrm{X}$, tais que B está entre A e X é uma semirreta AB;

3. a reunião de duas semirretas de mesma origem, não contidas em uma mesma reta é chamada de ângulo.

Há também as posições relativas de uma reta com um plano.

Pelo postulado 4, se uma reta possui dois pontos ou mais pertencentes a um plano, então todos os seus pontos estarão nesse plano. Se uma reta tem apenas um ponto em comum com um plano, ela é chamada de secante ao plano, e caso não tenha pontos em comum, ela é paralela ao plano.

Agora, consideremos as propriedades que envolvem posições relativas entre dois planos.

Proposição 2.1. Se dois planos possuem um ponto em comum, então, eles possuem pelo menos uma reta em comum.

Demonstração. Se dois pontos $\mathrm{P}$ e Q são comuns aos planos $\alpha$ e $\beta$, pelo postulado 2, esses pontos determinam uma reta. Se existe um ponto $\mathrm{R}$ comum aos planos que não 
pertencesse à reta determinada pelos pontos $\mathrm{P}$ e $\mathrm{Q}$, os planos seriam coincidentes pelo postulado 3 , logo eles possuem pelo menos uma reta em comum.

Definição (retas perpendiculares e ortogonais). Duas retas são perpendiculares se, e somente se, são concorrentes e formam ângulos adjacentes suplementares congruentes. Ou seja, o ângulo entre as retas é reto.

Definição (retas ortogonais). Se duas retas $\mathrm{r}$ e s forem reversas e formarem um ângulo reto, então elas são ditas ortogonais.

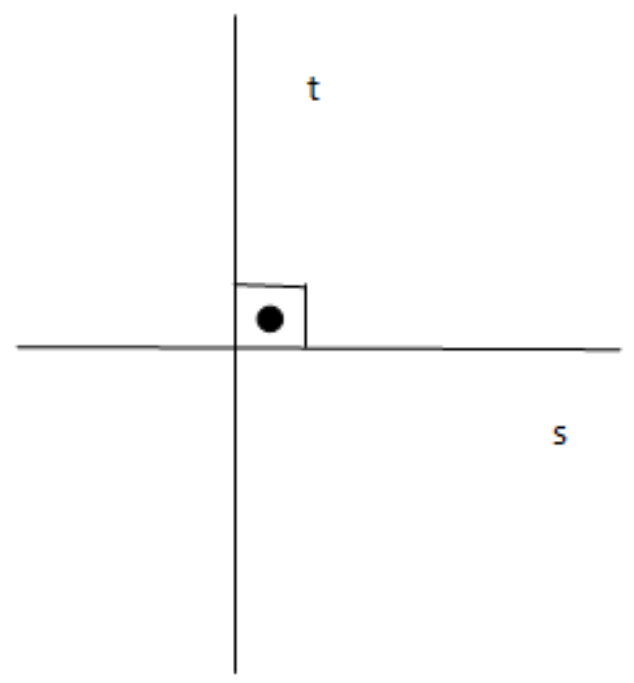

Figura 2.7: Retas perpendiculares. 


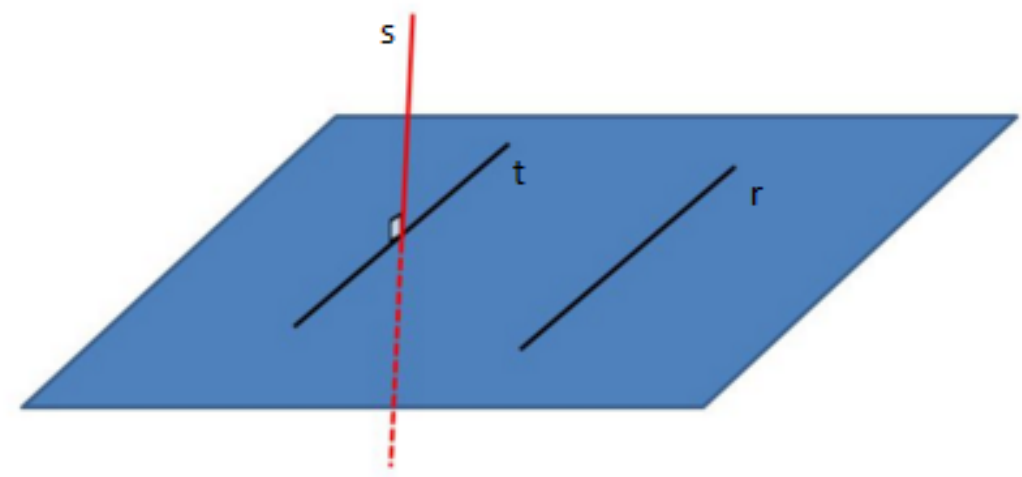

Figura 2.8: Reta $r$ em outro plano que não contenha $t$ e $s$ e ortogonal ao plano.

(Fonte: http://slideplayer.com.br/slide/7485754/ editado)

Uma reta é ortogonal ao plano quando ela é ortogonal a todas as retas desse plano.

Proposição 2.2. Em um plano por um ponto dado de uma reta dada passa uma única reta perpendicular à reta dada.

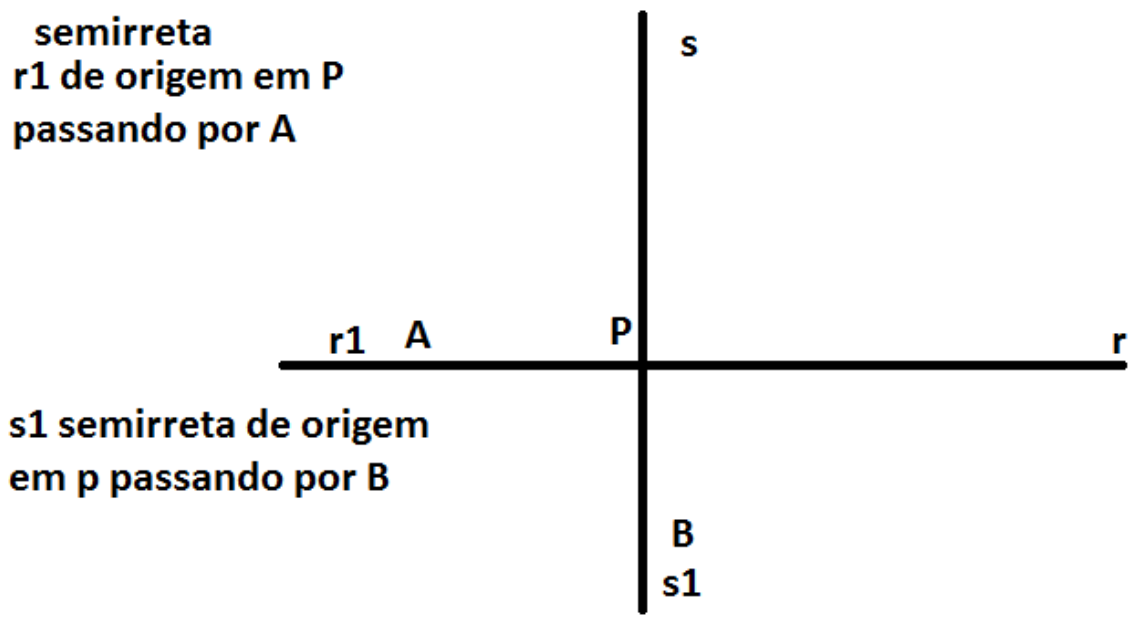

Figura 2.9: Figura proposição 2.2

Demonstração. Seja r uma reta e P um ponto dessa reta, construímos num dos semiplanos duas semirretas com origem em P, r1 e s1, onde r1 está em r e s1 forma um ângulo reto com r1. Logo a reta s que contém s1 é perpendicular a r. 
Suponha que existam duas retas distintas $\mathrm{x}$ e y perpendiculares a $\mathrm{r}$ passando por P. Assim as semirretas Px1 de x e Py1 de y no mesmo semiplano determinado por $r$ determinariam dois ângulos congruentes ao ângulo reto, o que é um absurdo por serem distintas e pelo transporte de ângulos acima. Logo existe e é única.

Proposição 2.3. Por um ponto dado fora de uma reta dada, existe uma e somente uma reta perpendicular à reta dada.

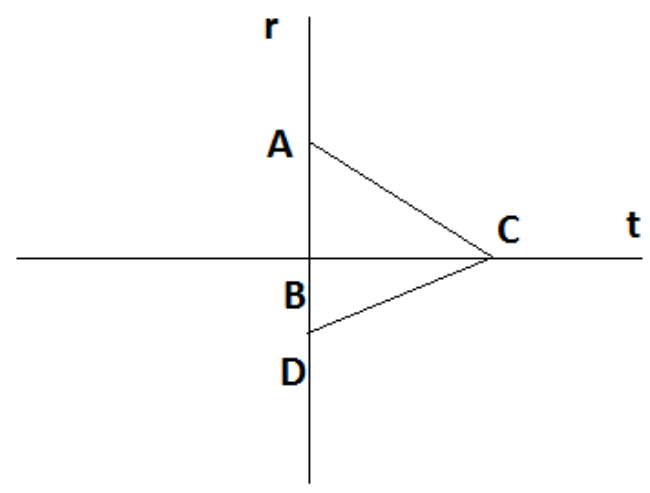

Figura 2.10: Figura proposição 2.3

Demonstração. Sejam o ponto $\mathrm{C}$ fora da reta $\mathrm{r}$ e dois triângulos retângulos com um dos lados contidos na reta $\mathrm{r}$, o Triângulo $\mathrm{ABC}$ e o triângulo $\mathrm{CDE}$, onde por ordem $\mathrm{A}$ está à esquerda de B e D está à esquerda de E. Supor, por absurdo, que B não coincida com D. Logo, existe um triângulo CBD com dois ângulos retos, o que é um absurdo. Assim fazendo $t$ a reta que passa por $\mathrm{C}$ e $\mathrm{B}$, portanto t é a única reta perpendicular a $\mathrm{r}$ por esse plano.

\subsection{Triângulos, quadriláteros e outros polígonos}

\subsubsection{Triângulos}

Definição (triângulos). Dados três pontos quaisquer não colineares, a reunião dos segmentos de reta formados por eles chama-se triângulos.

Indicação: triângulo $\mathrm{ABC}=\triangle A B C=\overline{A B} \cup \overline{A C} \cup \overline{B C}$

Elementos de um triângulo $\mathrm{ABC}$ são os vértices, que são os pontos $\mathrm{A}, \mathrm{B}$ e $\mathrm{C}$, os lados $\overline{A B}$ de medida c, $\overline{B C}$ de medida a e $\overline{A C}$ de medida b, e os ângulos $A \hat{B} C, B \hat{A} C$ e $A \hat{C} B$, conforme pode-se observar na figura abaixo: 


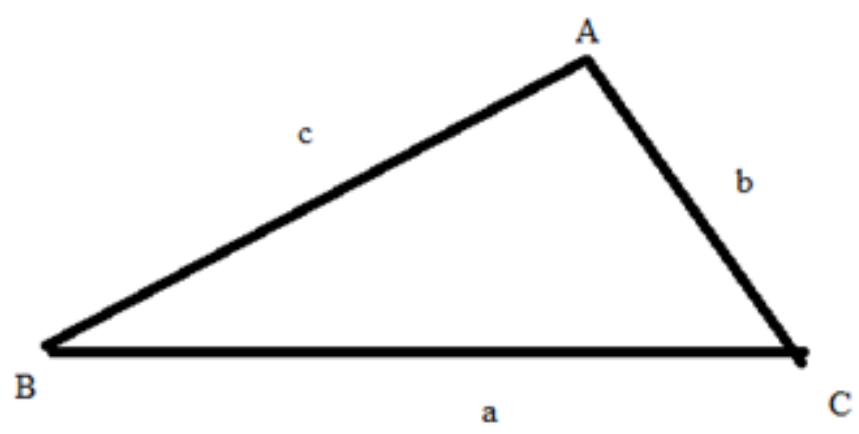

Figura 2.11: Triângulo ABC.

Classificação dos triângulos quanto aos lados:

- Equiláteros: se os três lados são congruentes, ou seja, tem a mesma medida;

- Isósceles: se têm dois lados congruentes;

- Escalenos: se os lados não são congruentes.

Classificação dos triângulos quanto aos ângulos:

- Retângulos: se têm um ângulo reto;

- Acutângulos: se os três ângulos são agudos;

- Obtusângulos: se têm um ângulo obtuso.

Definição (congruência de triângulos). Um triângulo é congruente a outro se, e somente se, for possível estabelecer uma correspondência entre seus vértices de tal modo que seus lados e ângulos sejam ordenadamente congruentes aos lados e ângulos do outro. Os casos de congruência de triângulos são:

- se dois triângulos têm ordenadamente congruentes dois lados e o ângulo compreendido entre eles (caso LAL);

- se dois triângulos têm ordenadamente um lado e os dois ângulos adjacentes a esses lados (caso ALA); 
- se dois triângulos têm ordenadamente congruentes os três lados (caso LLL);

- se dois triângulos têm ordenadamente congruentes um lado, um ângulo adjacente e o ângulo oposto a esse lado (caso LAAo).

Nos casos de congruência de triângulos, vale a pena observar que ordenadamente não quer dizer que são exatamente na mesma posição, podem estar invertidos, inclinados, opostos um ao outro, entre outras.

\subsubsection{Quadriláteros}

Definição (quadriláteros). Sejam quatro pontos distintos A, B, C, D de um mesmo plano e três não colineares. Se os segmentos formados por eles $\overline{A B}, \overline{B C}, \overline{C D}, \overline{A D}$ interceptam-se apenas nas extremidades, a junção ou reunião desses segmentos é um quadrilátero.

Observação: os elementos de um quadrilátero são os mesmos do triângulo acrescidos daqueles formados pelo quarto ponto e as diagonais $\mathrm{AC}$ e BD.

Os quadriláteros notáveis são os trapézios (se possuem dois lados paralelos), os paralelogramos (se possuem os lados opostos paralelos), os retângulos (se possuem os quatro ângulos congruentes), os losangos (se possuem os quatro lados congruentes) e os quadrados (se possuem os quatro ângulos congruentes e os quatro lados congruentes). 


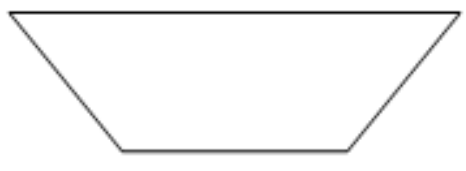

Trapézio.

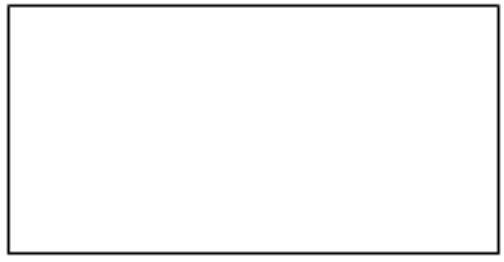

Retângulo.

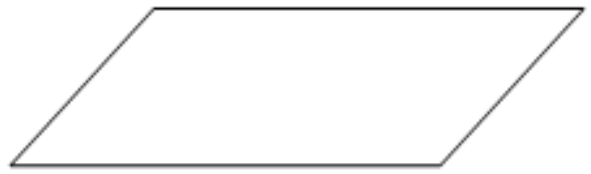

Paralelogramo.

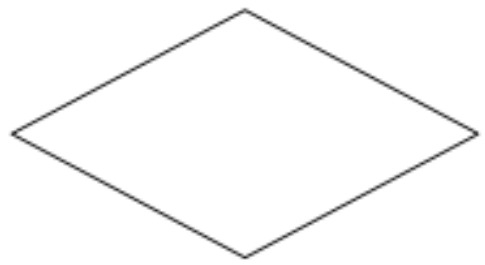

Losango.

Quadrado.

Figura 2.12: Quadriláteros notáveis.

Propriedades dos quadriláteros:

a) Em qualquer trapézio $\mathrm{ABCD}$ de bases $\mathrm{AB}$ e $\mathrm{CD}$, tem-se $\hat{A}+\hat{D}=\hat{B}+\hat{C}$.

Demonstração. Como as bases são paralelas, os lados AD e BC são as transversais que passam pelas paralelas, logo, transportando os ângulos, tem-se a propriedade acima.

b) Em todo paralelogramo, dois ângulos opostos quaisquer são congruentes.

Demonstração. Como os lados opostos são paralelos e usando a propriedade a) com as bases $\mathrm{AB}$ e $\mathrm{CD}$ e depois com as bases $\mathrm{AD}$ e $\mathrm{BC}$, tem-se que os ângulos opostos são congruentes.

c) Todo quadrilátero convexo que tem ângulos opostos congruentes é paralelogramo.

Demonstração. Seja ABCD um quadrilátero convexo, com $\hat{A} \equiv \hat{C}$ e $\hat{B} \equiv \hat{D}$ o que implica que $\hat{A}+\hat{B}=\hat{C}+\hat{D}\left(^{*}\right)$. Como ABCD é um quadrilátero convexo, $\hat{A}+\hat{B}+\hat{C}+\hat{D}=360^{0}$ 
$\left({ }^{* *}\right)$, substituindo $\left(^{*}\right)$ em $\left(^{* *}\right) \hat{A}+\hat{B}=180^{\circ}$ e $\hat{C}+\hat{D}=180^{\circ}$ com a hipótese inicial $\hat{A}+\hat{B}=180^{\circ}$ e $\hat{A}+\hat{D}=180^{\circ}$. Logo os lados opostos são paralelos, o que implica que ABCD é um paralelogramo.

Observação: como consequência dessa propriedade, todo retângulo é um paralelogramo.

d) Em todo paralelogramo, dois lados opostos quaisquer são congruentes.

Para a demonstração basta observar que, no paralelogramo ABCD, os triângulos formados traçando-se a diagonal AC são congruentes, ou seja, o triângulo ACD é congruente ao triângulo ACB.

e) Todo quadrilátero convexo que tem lados opostos congruentes é paralelogramo.

Com o mesmo raciocínio da demonstração de d), segue essa propriedade.

Observação: como consequência todo losango é paralelogramo.

As próximas propriedades são demonstradas com semelhança de triângulos, dividindose pela diagonal.

f) Em todo paralelogramo, as diagonais interceptam-se nos respectivos pontos médios.

g) Todo quadrilátero convexo que tem dois lados paralelos e congruentes é um paralelogramo.

h) Em todo retângulo, as diagonais são congruentes.

i) Todo retângulo tem diagonais perpendiculares.

Observação: todo quadrado é retângulo e também losango.

Observação: Como consequência das propriedades acima, tem-se a medida da base média do triângulo e do trapézio. A base média do triângulo é paralela ao lado e mede metade deste mesmo lado. A base média do trapézio é paralela às bases e mede a semisoma das bases. 


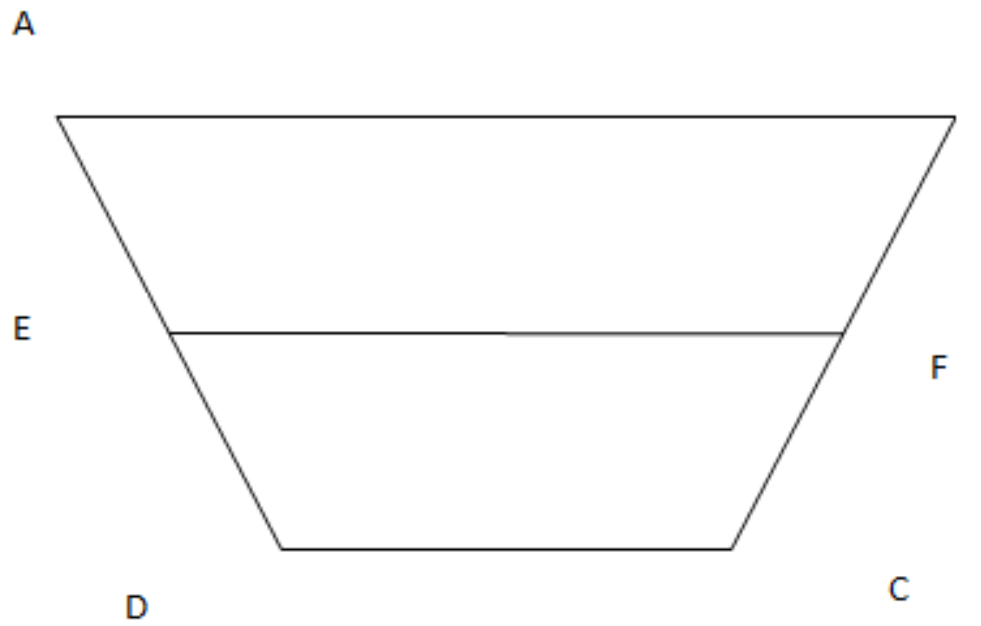

Figura 2.13: Trapézio semi-soma das bases.

Na figura 2.11 AE é congruente a ED e BF é congruente FC, com AB paralelo a DC.

\subsubsection{Polígonos}

Definição (polígono). Dada uma sequência de três ou mais pontos de um plano, todos distintos, onde três pontos consecutivos não são colineares, chama-se polígono a reunião dos segmentos formados dois a dois.

Propriedades:

a) O número de diagonais d de um polígono convexo de n lados é dado pela fórmula:

$$
d=\frac{n(n-3)}{2}
$$

b) A soma $S_{i}$ dos ângulos internos de um polígono convexo de n lados é dada pela fórmula:

$$
S_{i}=(n-2) \text { retos }
$$

c) A soma $S_{e}$ dos ângulos externos de um polígono convexo de n lados é dada pela fórmula:

$$
S_{e}=4 \text { retos }
$$

Essas propriedades podem ser demonstradas por indução e pela soma dos ângulos externos como consequência da soma dos ângulos internos. 


\subsection{Circunferência e círculo}

Definição (circunferência). É o conjunto dos pontos de um plano cuja distância a um ponto dado (centro da circunferência) é igual a uma distância fixa (raio). A corda de uma circunferência é o segmento cujas extremidades pertencem à circunferência. $\mathrm{O}$ diâmetro é a corda que passa pelo centro da circunferência.

Definição (círculo). É o conjunto de pontos de um plano cuja distância a um ponto dado é menor ou igual a uma distância dada.

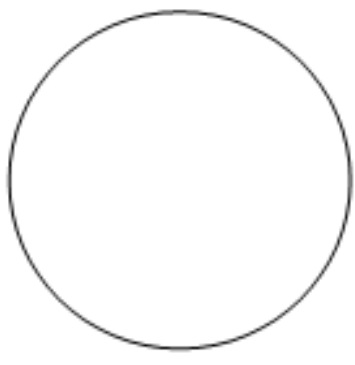

Circunferência.

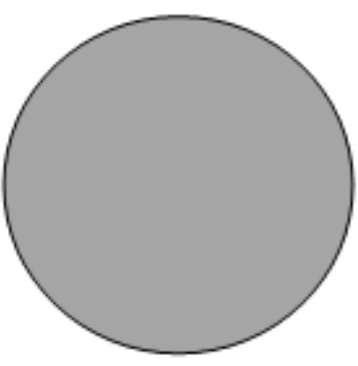

Círculo.

Figura 2.14: Circunferência e círculo.

Nas definições anteriores, pode-se observar que a circunferência representa "a linha traçada", e o círculo representa "essa linha"e o interior dela.

Definição (setor circular). É a reunião dos conjuntos dos pontos situados entre dois raios. 


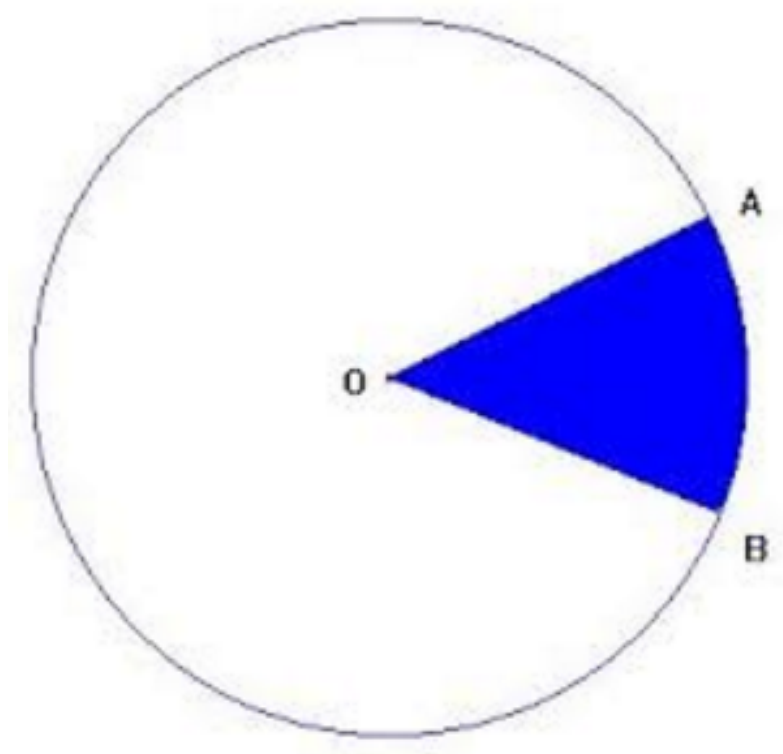

Figura 2.15: Setor circular, o interior de OA, OB e $\overparen{A B}$.

(Fonte: http://euler.mat.ufrgs.br/ ensino2/ano2006/alunos/31/setor2.html)

Definição (segmento circular). É a intersecção do círculo com o semiplano formado por uma corda.

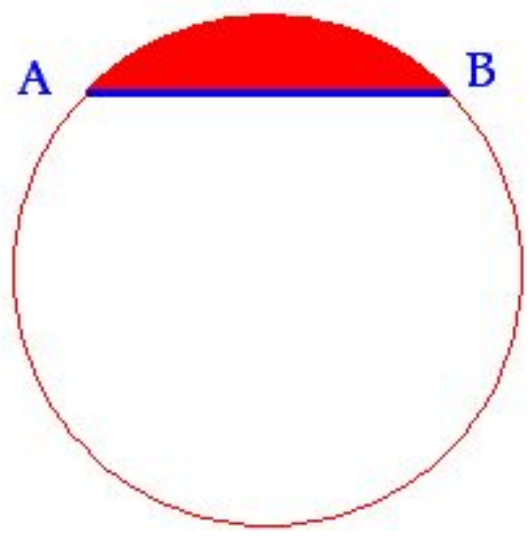

Figura 2.16: Segmento circular.

(fonte:http://www.aulafacil.com/cursos/110836/ciencia/matematicas/areasgeometricas / calculo-del-area-de-un-segmento-circular)

Observação: o semicírculo é um segmento circular cuja corda passa pelo centro (diâmetro). 


\subsubsection{Propriedades importantes envolvendo a circunferência e o círculo}

a) Toda tangente a uma circunferência é perpendicular ao raio no ponto de tangência.

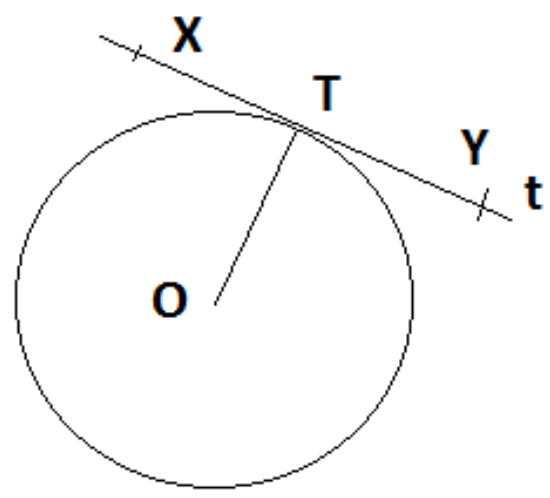

Figura 2.17: Figura propriedade a)

Demonstração. Seja t uma reta tangente à circunferência, e $\mathrm{T}$ o ponto de intersecção. E sejam dois pontos $\mathrm{X}$ e $\mathrm{Y}$ em t tal que $\mathrm{T}$ está entre $\mathrm{X}$ e Y e TX é congruente a TY. Se t não fosse perpendicular OT, então OT comum e perpendicular TX implicaria dois triângulos congruentes, triângulo OTX e triângulo OTY, o que implica OX congruente a OY, portanto t intercepta a circunferência em dois pontos X e Y, o que é um absurdo. Logo t é perpendicular a OT.

b) Seja um ponto $\mathrm{P}$ exterior à circunferência e dois segmentos PA e PB, ambos tangentes à circunferência, com A e B pertencentes à circunferência. Logo esses segmentos são congruentes.

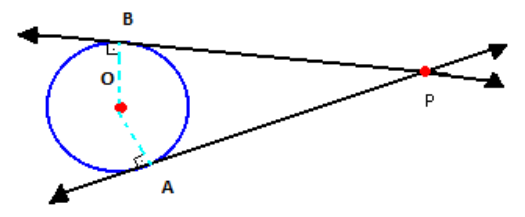

Figura 2.18: Figura propriedade b) 
Demonstração. Considere o ponto O, centro dessa circunferência. Assim temos que AO e OB são congruentes, pois são raios, PA é perpendicular a OA e PB é perpendicular a $\mathrm{OB}$, o que implica que os triângulos POA e POB são congruentes, logo PA e PB têm a mesma medida.

Como consequência dessa propriedade, se um quadrilátero convexo é circunscrito a uma circunferência, a soma dos lados opostos é igual à soma dos outros dois.

c) Dada uma circunferência qualquer, o perímetro de qualquer polígono convexo nela inscrito é menor que o perímetro de qualquer polígono a ela circunscrito. Logo a razão entre o perímetro do círculo e seu diâmetro é um número constante representado por $\pi$. Considere uma circunferência de comprimento C. Devido a essa propriedade, podese considerar um polígono $p_{n}$ inscrito e outro $P_{n}$ circunscrito, tal que $p_{n}<C<P_{n}$. Dividindo-se pelo dobro do raio:

$$
\frac{p_{n}}{2 R} \leq \frac{C}{2 R} \leq \frac{P_{n}}{2 R}
$$

E aplicando o limite:

$$
\lim _{n \rightarrow \infty} \frac{p_{n}}{2 R} \leq \lim _{n \rightarrow \infty} \frac{C}{2 R} \leq \lim _{n \rightarrow \infty} \frac{P_{n}}{2 R}
$$

Obtém-se:

$$
\frac{C}{2 R}=\pi
$$

\section{5 Área de superfícies planas}

Definição (área de uma superfície plana). É um número real positivo que associa a superfície de tal forma que superfícies equivalentes estão associadas a áreas iguais. Se uma está dentro da outra, a que está dentro tem área menor, e a soma de superfícies é a reunião disjunta da área de suas parcelas.

A área do retângulo é dada pelo produto da medida da base pela medida da altura, em vista de dois teoremas importantes anunciados abaixo.

Teorema 2.5.1. A razão entre dois retângulos de bases congruentes (ou alturas congruentes) é igual à razão entre suas alturas (ou bases).

Teorema 2.5.2. A razão entre dois retângulos quaisquer é igual ao produto da razão entre as bases pela razão entre as alturas. 
Tabela 2.1: Polígonos e suas respectivas áreas.

\begin{tabular}{l|r}
\hline Polígono & Área \\
\hline Quadrado & $A_{q}=l^{2}$ \\
\hline Paralelogramo & $A_{P}=b . h$ \\
\hline Triângulo & $A_{t}=\frac{b . h}{2}$ \\
\hline Triângulo equilátero & $A_{t e}=\frac{l^{2} \sqrt{3}}{4}$ \\
\hline Trapézio & $A_{t} r a p=\frac{(B+b) h}{2}$ \\
\hline Losango & $A_{\text {losango }}=\frac{D d}{2}$ \\
\hline Hexágono regular & $A_{\text {hex }}=\frac{3 l^{2} \sqrt{3}}{2}$ \\
\hline
\end{tabular}

Assim a área do retângulo $A_{R}=b . h$, onde b é a medida da base e h é a medida da altura.

As áreas de outros polígonos são comparadas com as áreas dos retângulos.

Nessas expressões, $l$ é a medida do lado, $b$ da base, $B$ da base maior, h da altura e $d$ da diagonal menor e $D$ da diagonal maior.

\subsection{Poliedros}

Definição (poliedros). É a reunião de um número finito de polígonos planos, onde cada lado de um desses polígonos é também lado de um, e apenas um, outro polígono. Cada um desses polígonos chama-se face do poliedro, cada lado comum a duas faces chama-se aresta do poliedro. Ou seja, são sólidos formados por faces (partes limitadas de um plano).

Definição (poliedro convexo). Pode-se dizer que um poliedro é convexo se qualquer reta não paralela a nenhuma das faces intersecta suas faces, em no máximo dois pontos.

Teorema 2.6.1. (Relação de Euler) Em todo poliedro convexo com arestas A, vértices $V$ e faces $F$, vale a relação $V+F=A+2$.

\subsubsection{Poliedros notáveis}

São poliedros com características diferenciadas:

- convexos;

- todas as faces são polígonos regulares e congruentes; 
- em todos os vértices, concorre um mesmo número de arestas;

- cada vértice pertence ao mesmo número de faces;

- seus ângulos são congruentes.

São apenas cinco poliedros regulares: o tetraedro, o hexaedro, o octaedro, o dodecaedro e o icosaedro.

\subsubsection{Outros poliedros}

Paralelepípedo retângulo é um poliedro formado por seis retângulos. Seu volume é representado multiplicando-se suas dimensões, pois ele é proporcional a cada uma de suas dimensões. Assim, um paralelepípedo com altura (a), largura (b) e comprimento (c) tem seu volume $\left(V_{\text {parleleleppedo }}\right)$ calculado por: $V_{\text {paraleleppedo }}=a . b . c$, ou seja $V_{\text {paraleleppedo }}=A_{b} . h$, em que $A_{b}$ é área da base e $h$ é a altura.

O cubo é um paralelepípedo retângulo com as dimensões (arestas) congruentes. Assim, o volume Vcubo é calculado por: $V_{c u b o}=a^{3}$.

Para o cálculo do volume de outros poliedros é importante saber o Princípio de Cavalieri.

Axioma 2.6.1. (Princípio de Cavalieri). Considere dois sólidos e um plano dados. Se todo plano paralelo ao plano dado secciona (corta) os dois sólidos formando figuras de mesma área, então esses sólidos têm o mesmo volume.

O prisma é um poliedro com duas de suas faces formadas por polígonos convexos e congruentes que estão em planos paralelos, chamados de bases, e as demais faces são paralelogramos que possuem arestas comuns com suas bases.

Sabendo-se disso e usando se o Princípio de Cavalieri, o volume de um prisma é comparado com o do paralelepípedo retângulo.

Pirâmide é um poliedro que possui uma face convexa, na qual estão todos os vértices do poliedro, exceto um, e as demais faces são triângulos que possuem um lado em comum com a face poligonal e todos os triângulos possuem um único vértice em comum.

Teorema 2.6.2. O volume de uma pirâmide triangular é igual a um terço do produto da área da base pela altura.

Demonstração. Seja um prisma com as bases triangulares com vértices $\mathrm{ABC}$ e DEF e altura h. Dividindo se esse prisma em três tetraedros de mesmo volume, o primeiro formado pela base DEF e outro vértice $\mathrm{A}$, o segundo de base ACF e outro vértice $\mathrm{E}$, e o último de base $\mathrm{ABC}$ e outro vértice $\mathrm{E}$. Assim o volume do prisma é a soma do volume dos três tetraedros de volume igual, o que prova o teorema. 


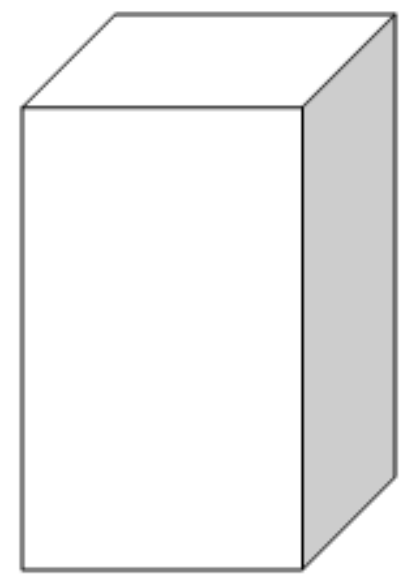

Figura 2.19: Prisma.

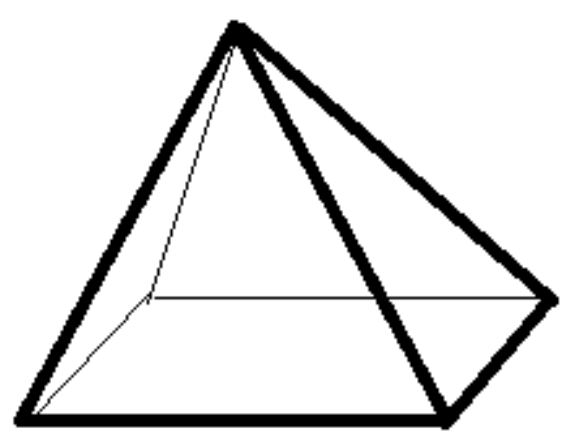

Figura 2.20: Pirâmide.

Teorema 2.6.3. O volume de qualquer pirâmide é igual a um terço da área da base pela altura.

Demonstração. Dividindo-se a base da pirâmide em triângulos, partindo de um mesmo vértice que esteja na base, basta somar as áreas dos triângulos de base triangular obtida dos triângulos divididos anteriormente pelo vértice e ao juntar cada vértice com que não está na base, obtêm-se várias pirâmides de base triangular. Assim, como sua área da base, pelo teorema anterior, é $\frac{A_{1}}{3}, \frac{A_{2}}{3}, \frac{A_{3}}{3}, \ldots, \frac{A_{n}}{3}$, e colocando-se em evidência as áreas e multiplicando-se pela altura, tem-se $V_{\text {pirmide }}=\frac{1}{3} \cdot\left(A_{1}+A_{2}+A_{3}+\ldots+A_{n}\right) \cdot h$, como $A_{1}+A_{2}+A_{3}+\ldots+A_{n}=A_{b}$, em que $A_{b}$ é a área da base. Assim, fica provado o teorema.

Cilindro é sólido de revolução formado por um retângulo que gira em torno de um de 
seus lados.

Cone é um sólido de revolução formado por um triângulo retângulo que gira em torno de um de seus catetos.

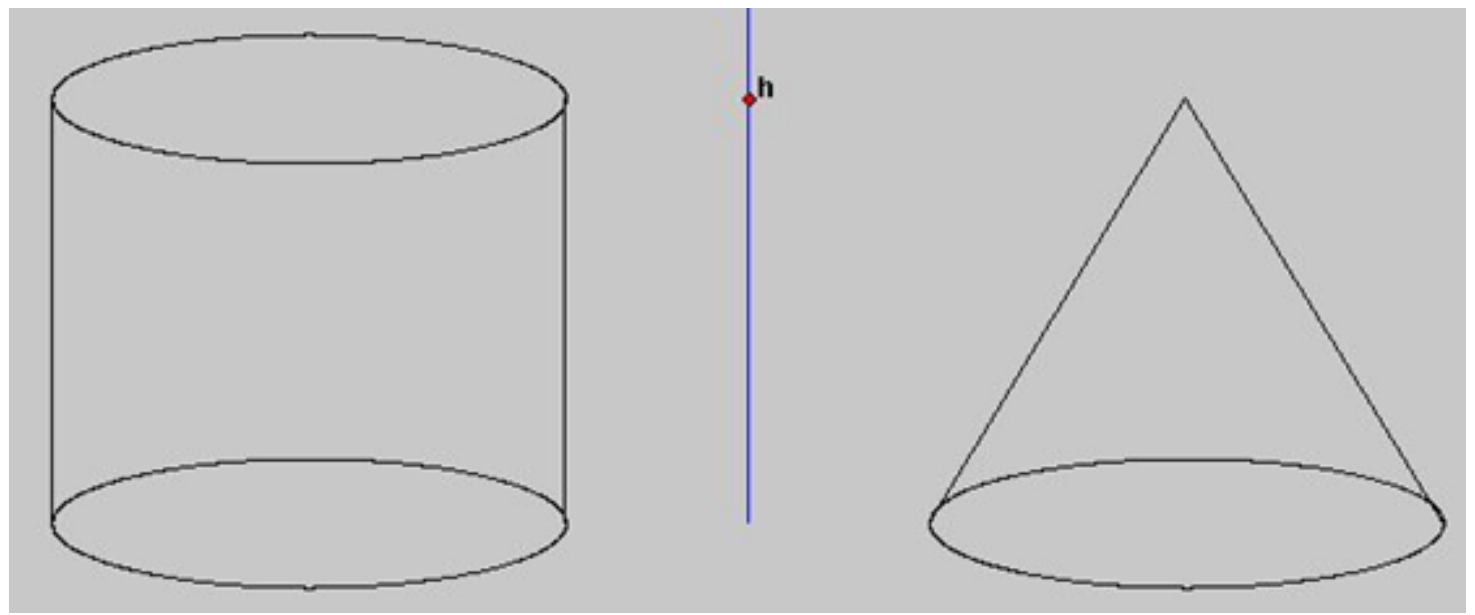

Figura 2.21: Cilindro e cone.

(Fonte: https://www.portaldasescolas.pt)

Para calcular o volume desses sólidos de revolução, basta usar o Princípio de Cavaliere e comparar o cilindro com um prisma de mesma base e altura, e o cone com uma pirâmide.

Esfera é um sólido de revolução formado por um círculo em torno do seu diâmetro.

Usando-se o Princípio de Cavalieri, pode-se determinar o volume da esfera. Para isso, considere um sólido de volume conhecido, tal que as seções nele e na esfera produzidas por planos horizontais tenham áreas iguais. Tome uma secção que dista uma altura h do centro da esfera de raio $\mathrm{R}$, então sua área é $\left(R^{2}-h^{2}\right) \pi$, que é a mesma da coroa circular limitada por duas circunferências de raios $\mathrm{R}$ e $\mathrm{h}$.

No próximo capítulo, será dado um exemplo que ilustra o que foi feito anteriormente (Atividade 5: volume de uma esfera a partir de um cilindro e um cone). Agora considere esse sólido como um cilindro de raio $\mathrm{R}$, apoiado num mesmo plano horizontal que a esfera. Assim o volume da esfera é o volume do cilindro subtraído de dois cones de volumes iguais pelo raciocínio acima.

Como a altura do cilindro é a mesma da esfera, $\log o \pi R^{2} \cdot 2 R-2 \cdot\left(\frac{1}{3} \pi R^{3}\right)=\frac{4}{3} \pi R^{3}$ é o volume da esfera. 


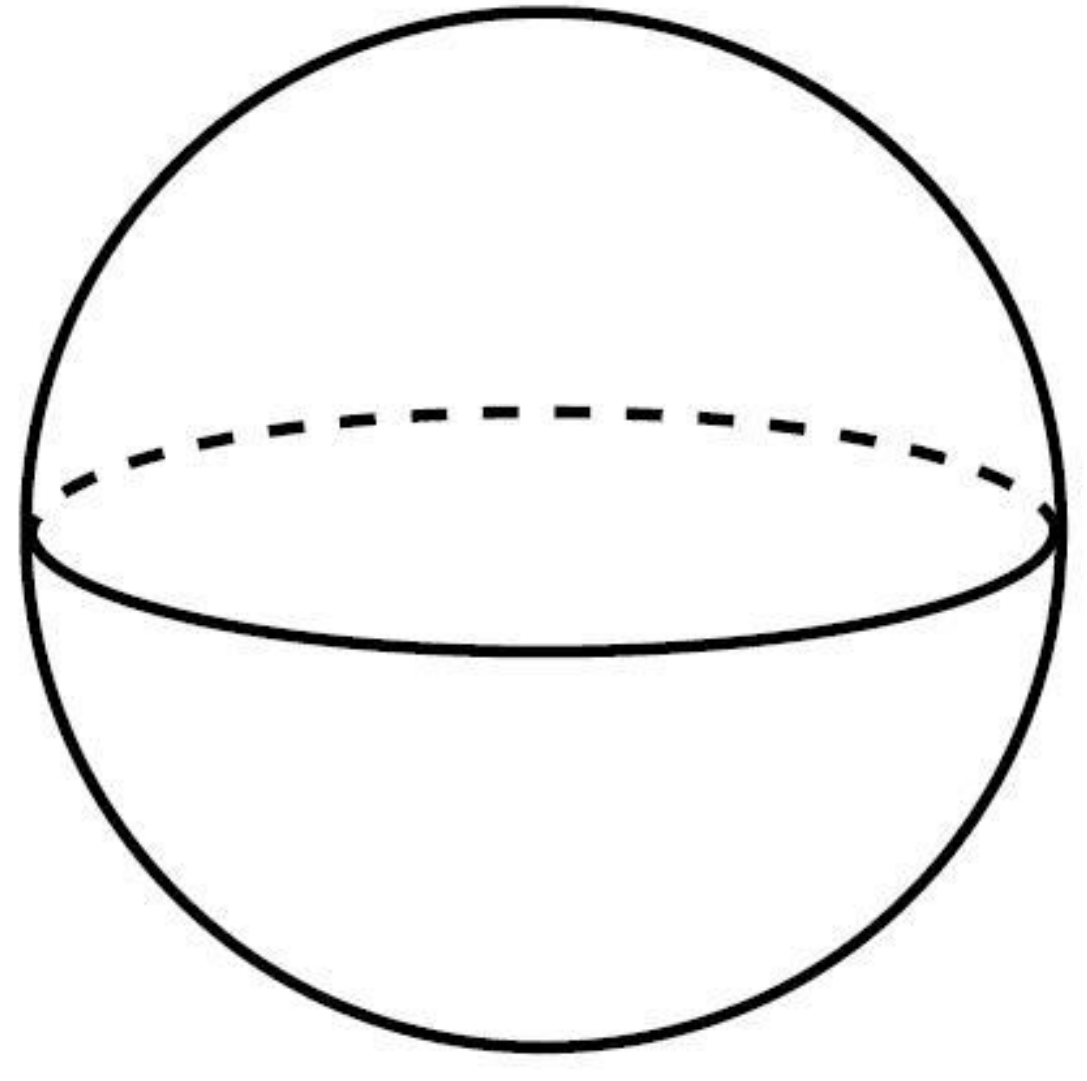

Figura 2.22: Esfera. 


\section{$\left[-\left[\begin{array}{c}\text { Coptulal } \\ 3\end{array}\right]\right.$ \\ Algumas atividades contextualizadas e práticas para serem trabalhadas com os alunos}

Para motivar o aluno do ensino fundamental e médio, devem-se acrescentar atividades que envolvam sua realidade, jogos de que ele possa participar com seus colegas, atividades contextualizadas, outras atividades que o incentivem e atividades inovadoras.

\subsection{Jogo de dardo}

O jogo de dardo consiste em acertar o dardo no alvo central marcado por um círculo e, em volta desse círculo, setores circulares com uma pontuação marcada. Nessa atividade o aluno vai identificar o círculo e os setores circulares, calcular a área e relacionar com os pontos obtidos no jogo. 


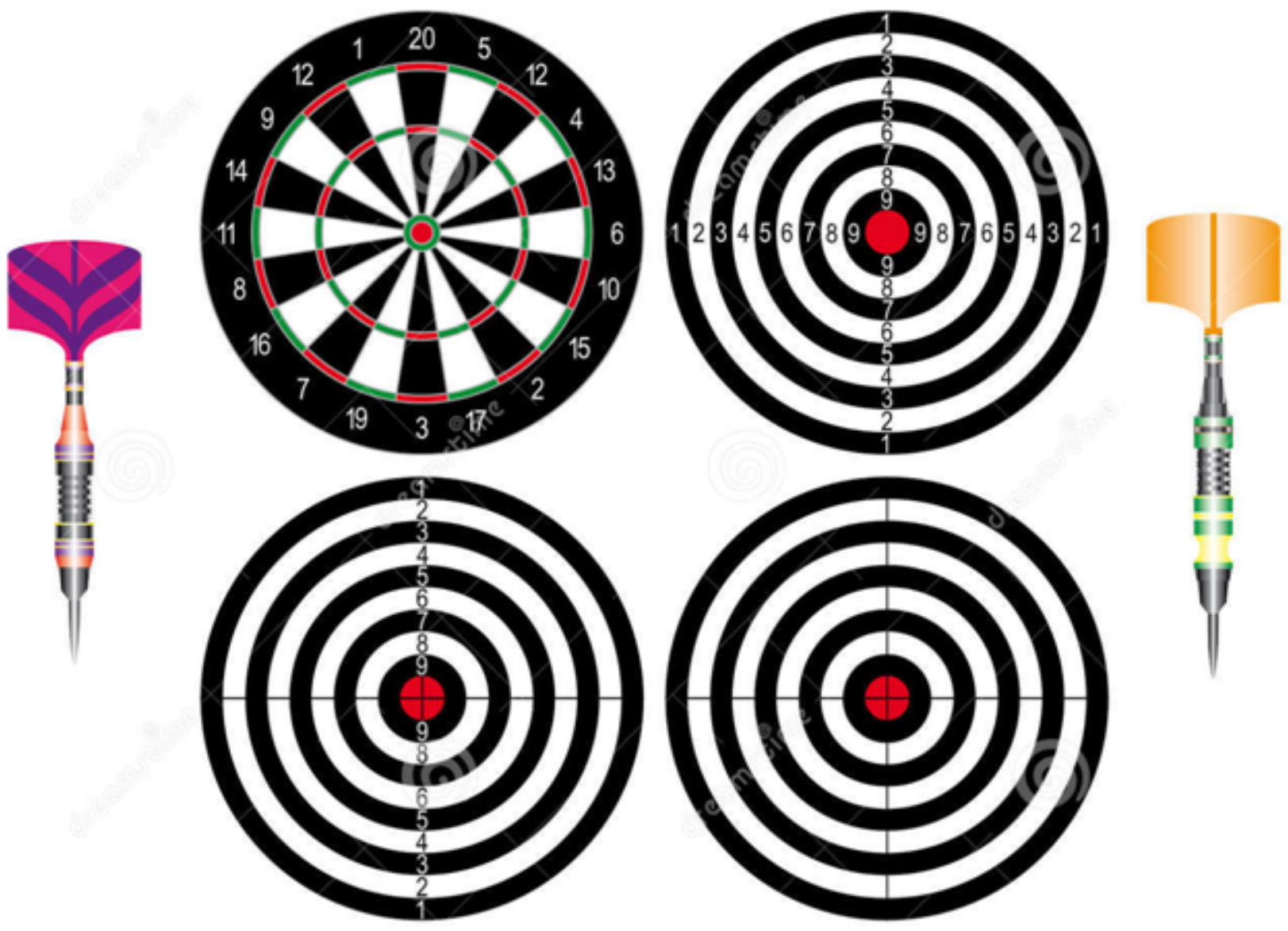

Figura 3.1: Jogo de dardo 1.

Fonte:(http://pt.dreamstime.com/fotos-de-stock-royalty-free-dardos-profissionaisimage26473938, acesso em

02/02/2016). 


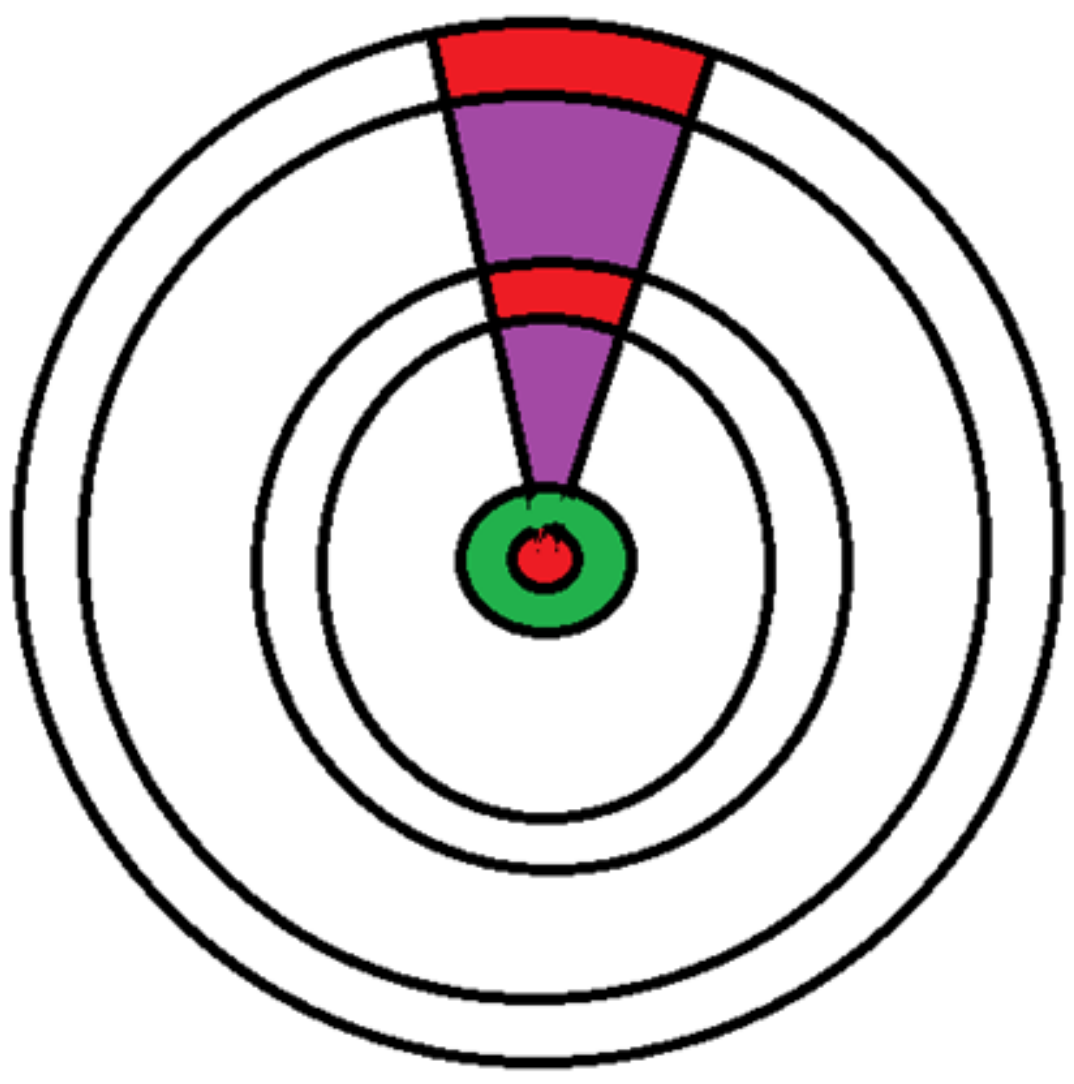

Figura 3.2: Jogo de dardo 2.

Proposta de atividade.

1- Construir o jogo de dardos. Nessa atividade, é interessante ter uma imagem e cada grupo de alunos pode decidir as medidas.

Observação: no tabuleiro de dardo a medida do seu diâmetro é de 42 centímetros, mas como aqui o importante é a contextualização, é interessante fazer o aluno (o grupo) escolher as medidas. E fazer o aluno pensar em quais medidas.

2- Calcular as áreas encontradas (as partes que estão em: vermelho, verde e roxo na figura jogo de dardo 2).

3- Relacionar a área encontrada com a pontuação.

4- Fazer os alunos criarem o jogo de dardo com outras figuras. Essa atividade pode ser um incentivo para a criação da atividade final.

\subsection{Construção de uma ponte em miniatura}

A função de uma ponte é facilitar a passagem por ambientes movimentados ou de difícil acesso por vários motivos. Nessa atividade, serão aperfeiçoadas as noções das posições 
relativas.

Proposta de atividade.

1. Construir uma ponte com papel e materiais de fácil acesso, como palitos ou espaguete.

2. Relacionar a ponte com as posições relativas (paralelos, perpendiculares, concorrentes, entre outros).

3. Verificar as medidas com transferidor e régua.

\subsection{Cálculo de alturas pela sombra}

Ao se calcularem alturas de prédios, pessoas, monumentos usando uma medida conhecida o estudante aprende sobre perpendicularismo, o teorema de Tales de Mileto e semelhança de triângulos.

Proposta de atividade.

1. Pegar um objeto que seja de fácil medição (cadeira de uma sala, mesa, uma régua, um aluno, entre outros) e medi-lo.

2. A partir desse objeto, medir sua sombra e a sombra do outro que se deseja obter.

3. Fazer os cálculos e descobrir a altura do novo objeto.

4. Comparar medindo (se possível) ou pesquisando a altura encontrada.

\subsection{Volumes de prismas e pirâmides}

A partir de um pedaço de uma barra de sabão, recortar os pedaços em forma pirâmides de volumes iguais e assim comparar os volumes encontrados. 


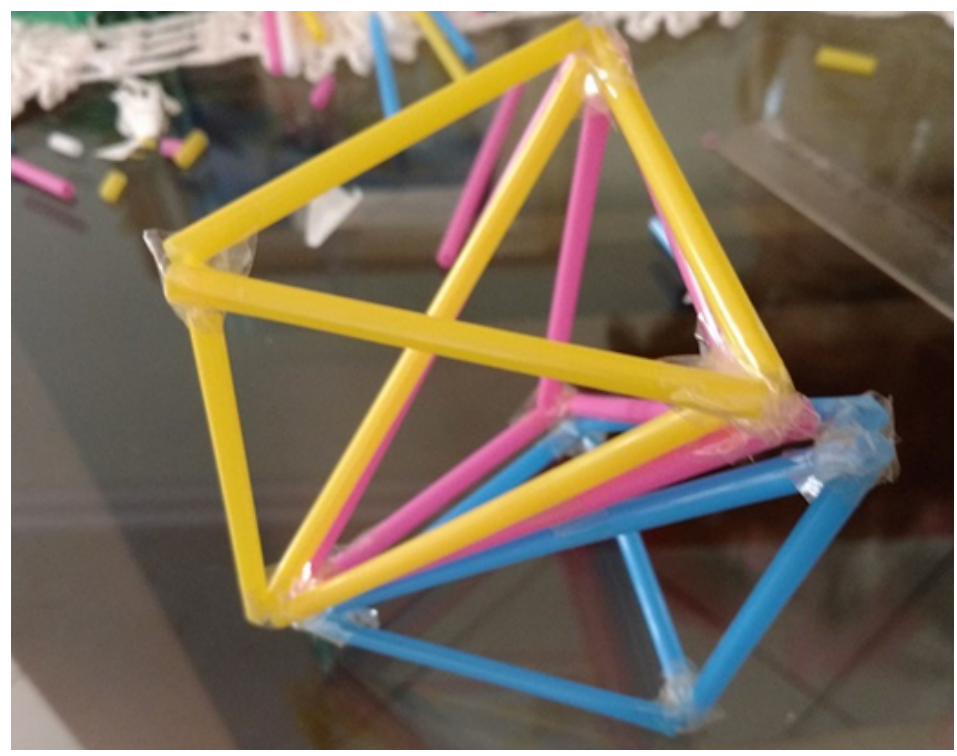

Figura 3.3: Imagens prisma e pirâmide feitas com canudos com indicação de corte com canudos brancos.

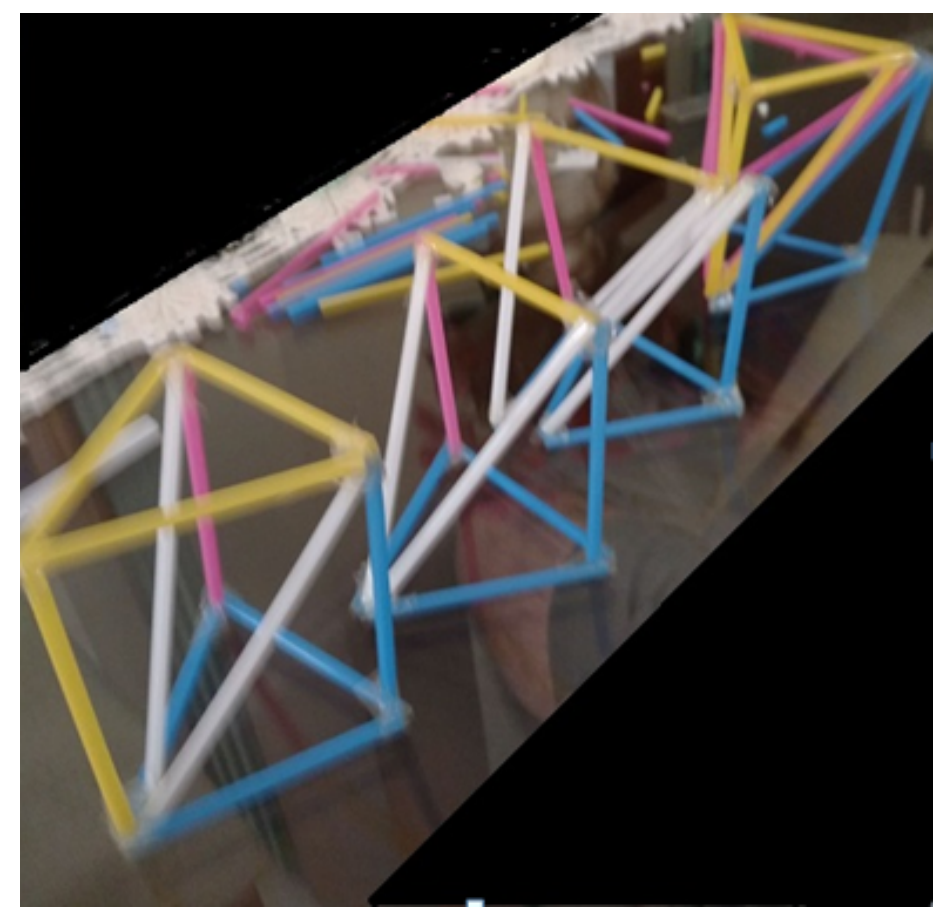

Figura 3.4: Imagens prisma e pirâmide feitas com canudos com indicação de corte com canudos brancos.

Proposta de atividade.

1. A partir de um pedaço de barra de sabão, em formato de um prisma com as bases triangulares, deve-se orientar o aluno a fazer os cortes como na demonstração do capítulo 
2 (na atividade proposta, foram utilizados os prismas e as pirâmides acima para auxiliar o recorte das barras de sabão).

2. Tendo os pedaços, comparar esse volume com o original (três pedaços feitos com recorte formam um prisma).

3. Fazer os cálculos para determinar o volume.

\subsection{Volume da esfera a partir de um cilindro e um cone}

No exercício de construção do volume, é importante destacar o princípio de Cavalieri. Podem-se usar outras figuras que têm volumes semelhantes. E com isso se calcular o volume de uma esfera.

Proposta de atividade.

1. A partir de uma esfera oca, recortar a mesma ao meio e preencher com um material que seja fácil transferir, como um líquido, areia, arroz.

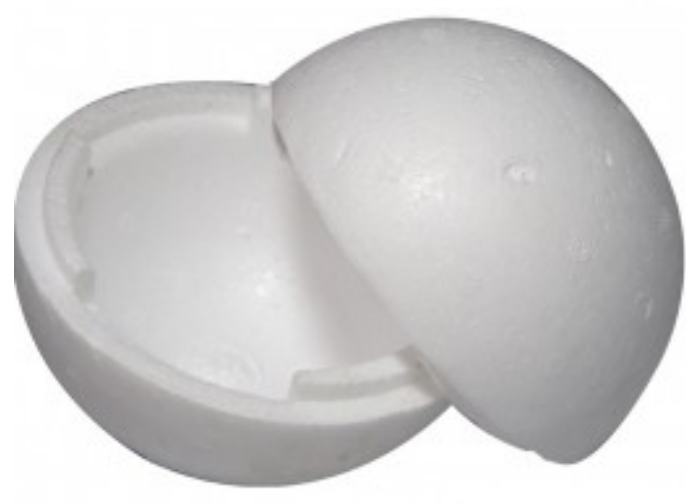

Figura 3.5: Isopor em formato de uma meia-esfera

2. Construir um cilindro também oco com a mesma altura da semiesfera e sua base com o mesmo raio, e fazer o mesmo com o cone de forma que esse cone caiba dentro do cilindro, conforme imagem, sem que o material seja desperdiçado ao se transferir.

3. Transferir o material entre os dois objetos e observa a proporção encontrada.

4. Fazer os cálculos para encontrar o volume da esfera.

5. Reforçar que foi possível fazer esses cálculos pela validade do princípio de Cavalieri. 


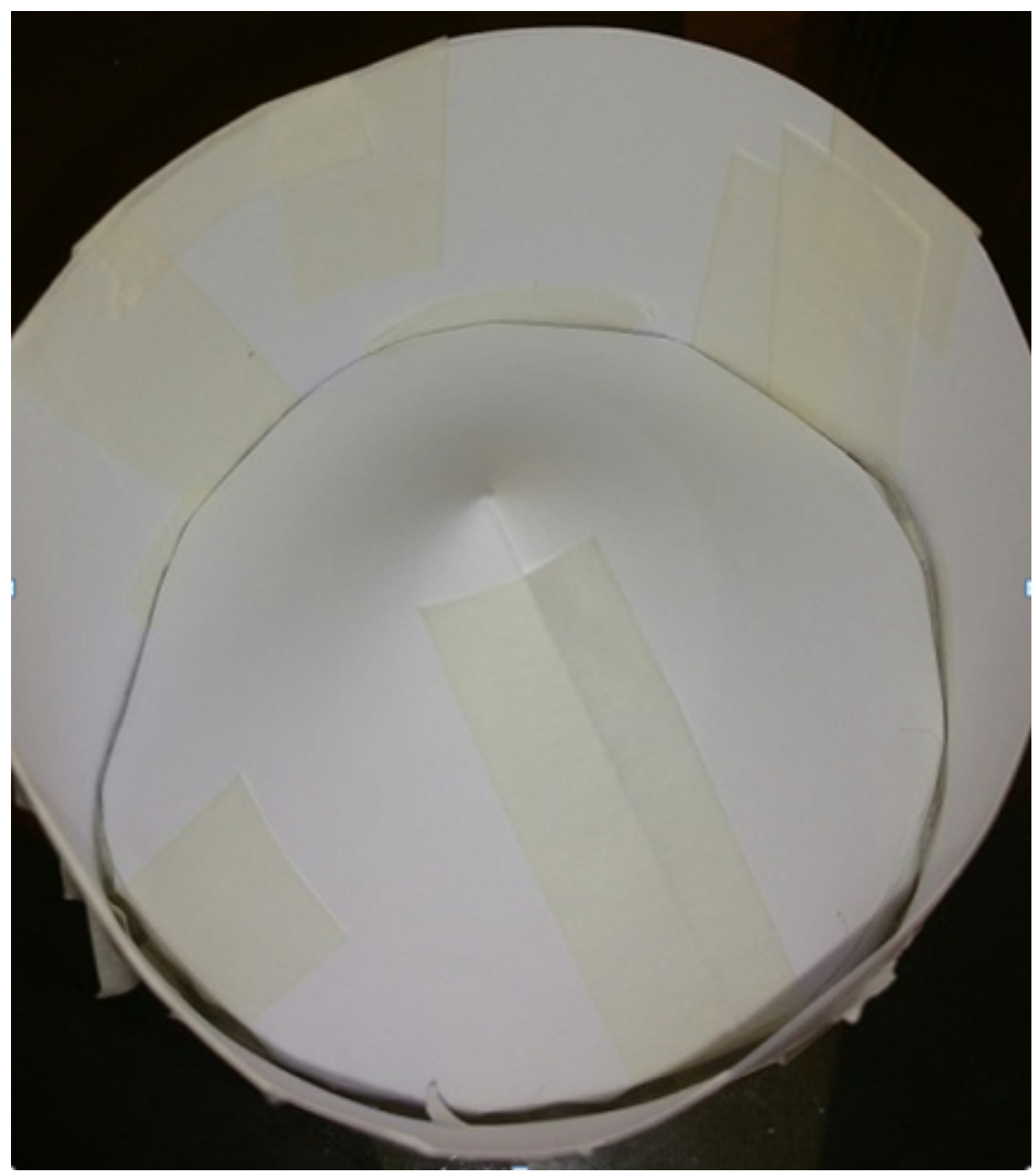

Figura 3.6: Cone com um cilindro feito com papel para se comparar com o volume da esfera.

\subsection{Geometria do motorista de táxi}

Essa geometria não-euclidiana o estudante pode aprender sobre distâncias, o cálculo da melhor distância nessa geometria e comparar com o da menor distancia euclidiana usando o teorema de Pitágoras.

Proposta de atividade.

1. Em uma folha de papel, desenhar com linhas as representações de ruas, que podem ser de onde mora, para isso, pode-se fazer uma pesquisa sobre o mapa do local, ou pegar algum mapa de uma região.

2. Localizar o melhor caminho entre dois pontos fixos, que pode ser entre dois locais.

3. Medir a distância encontrada e verificar se há mais alguma com medida semelhante.

4.Comparar essa distância com a traçada em linha reta (euclidiana), se possível usar o teorema de Pitágoras. 
5. Discutir o resultado obtido e encontrar outros exemplos em que se possa aplicar essa geometria.

\subsection{Geometria em uma esfera (Riemanniana)}

Em uma esfera de isopor, fazer um recorte de forma que ela fique dividida como na proposta abaixo, pode-se colocar uma situação hipotética para ficar mais claro, como comparar com um globo terrestre, ou uma laranja.

Essa atividade explora temas como distâncias e figuras não Euclidianas.

Proposta de atividade.

1. Traçar pela esfera de isopor uma linha que a divida ao meio.

2. E a partir dessa linha encontrar triângulos.

3. Observar os ângulos e ver o que foi obtido.

4. Responder à pergunta: pode-se dizer que nessa geometria formou-se um triângulo com três ângulos retos?

5. Discutir o cálculo das distâncias e comparar com os ângulos internos, se aumentar o ângulo entre dois pontos o que acontece com a medida.

\subsection{Criação de uma nova atividade em geometria}

A partir das atividades acima, os estudantes criarão uma nova atividade que envolva os conhecimentos adquiridos ou uma atividade em geometria. O professor deverá orientar para que a criação das atividades seja diferente das anteriores, poderá ser uma que envolva os materiais ou uma situação criada por eles, ou ainda reformular alguma atividade anterior ou uma aplicação em geometria. Nessa atividade, observar-se-ão, também, os conhecimentos adquiridos e a criação, como também se motivará o aperfeiçoamento.

Essa atividade tem como proposta avaliar os alunos quanto ao rendimento obtido nas atividades anteriores. Poderá ser utilizada como uma avaliação.

Após criarem essa atividade, eles encontrarão a solução e se há outros modos de se resolver a mesma.

1. Criar a nova atividade.

2. Ver quais conteúdos estão presente nessa atividade.

3. Solucionar a atividade.

Observação: essa atividade pode ser um parâmetro para ver o que foi aprendido. 


\section{$-\left[\begin{array}{c}\text { Copptula } \\ 4\end{array}\right]$ Metodologia e resultados das atividades}

Neste capítulo, são apresentados os resultados dos dados obtidos dos questionários aplicados a quatro turmas do ensino médio, sendo três turmas do segundo ano e uma turma do terceiro ano. Foram respondidos, ao todo, 128 questionários. As atividades foram realizadas entre os dias 30/11/2015 e 11/12/2015. O questionário encontra-se no anexo. Optou-se pela análise quantitativa das respostas às 5 primeiras perguntas e pela análise qualitativa das respostas à sexta pergunta, ancorando-se na metodologia de análise de conteúdo proposta por Bardin.

No plano metodológico, a querela entre a abordagem quantitativa e a abordagem qualitativa absorve certas cabeças. Na análise quantitativa, o que serve de informação é a frequência com que surgem certas características do conteúdo. Na análise é a presença ou ausência de uma dada característica de conteúdo ou de um conjunto de características num determinado fragmento de mensagem que é tomado em consideração.

(BARDIN 1977, pag.15)

Após inserir os dados obtidos, serão apresentados os dados em um gráfico de colunas para melhor visualização.

\subsection{Questão 1}

Na tabela 4.1 e na figura 4.1, são apresentados os resultados das respostas dos estudantes à questão 1 . 
Tabela 4.1: Quantitativo de respostas à questão 1: Seu interesse pelas atividades foi

\begin{tabular}{l|c|r}
\hline Opção & Número de marcações & Porcentagem aproximada. \\
\hline A)muito baixo. & 1 & $0,78 \%$ \\
\hline B)baixo. & 1 & $0,78 \%$ \\
\hline C)regular. & 12 & $9,37 \%$ \\
\hline D)bom. & 69 & $53,90 \%$ \\
\hline E)muito bom. & 44 & $34,37 \%$ \\
\hline Anulada* & 1 & $0,78 \%$ \\
\hline
\end{tabular}

*Anulado por ter marcado mais de duas opções.

\section{Seu interesse pelas atividades foi (em \%)}

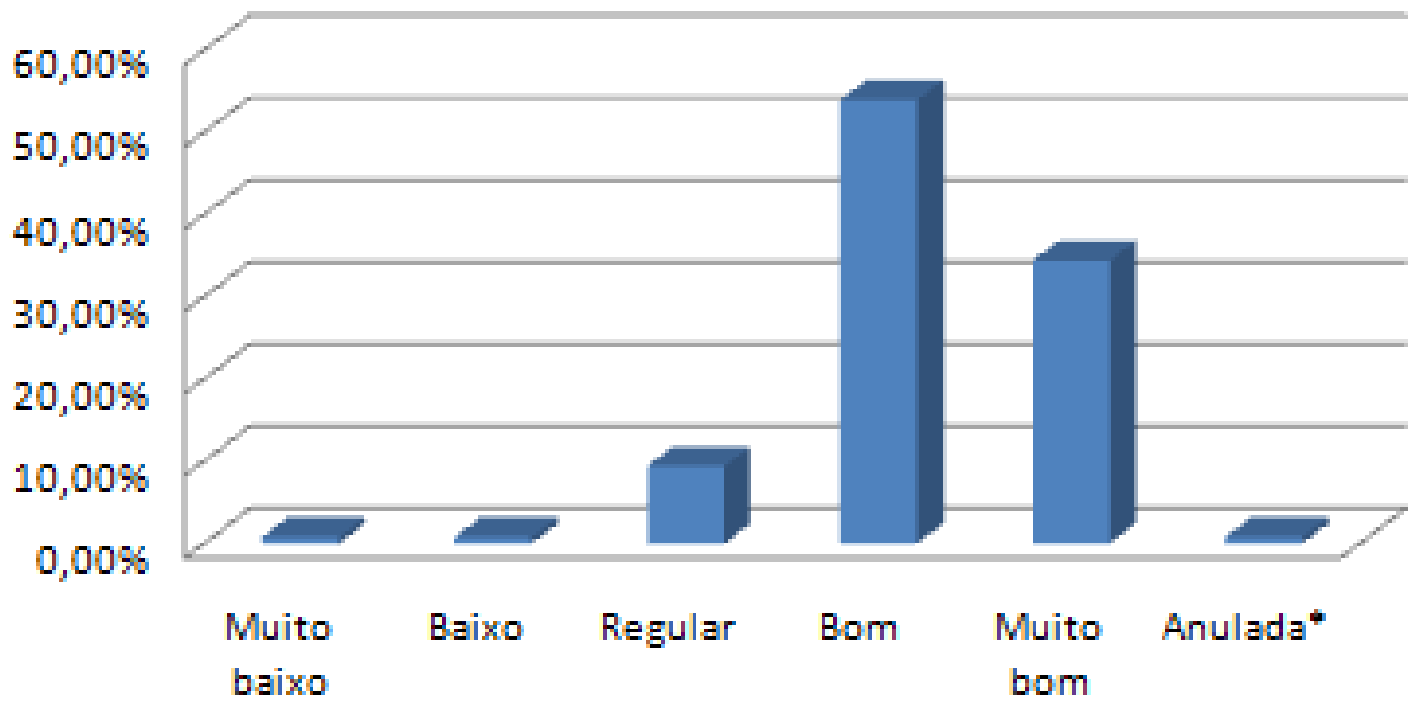

Figura 4.1: Porcentagem às respostas da questão 1. Gráfico feito pelo autor com os dados obtidos do item 1

De acordo com as respostas consideradas válidas, a maioria dos alunos se interessou pelas atividades, o que mostra a importância de diversificar, contextualizar as atividades de matemática (mais de 88\%), corroborando com a hipótese inicial desta pesquisa de que é importante esse tipo de trabalho em sala de aula para o interesse do aluno no aprendizado de geometria plana e espacial. 


\subsection{Questão 2}

Na tabela 4.2 e na figura 4.2, são apresentados os resultados das respostas dos estudantes à questão 2.

Tabela 4.2: Quantitativo de respostas à questão 2: Você já conhecia alguma dessas atividades?

\begin{tabular}{l|c|r}
\hline Opção & Número de marcações & Porcentagem aproximada. \\
\hline A) Não, nenhuma delas. & 80 & $62,50 \%$ \\
\hline B) Sim, pelo menos uma. & 30 & $23,44 \%$ \\
\hline C) Sim, algumas delas. & 13 & $10,16 \%$ \\
\hline D) Sim, a maioria delas. & 3 & $2,34 \%$ \\
\hline E) Sim, todas elas. & 1 & $0,78 \%$ \\
\hline Em branco & 1 & $0,78 \%$ \\
\hline
\end{tabular}

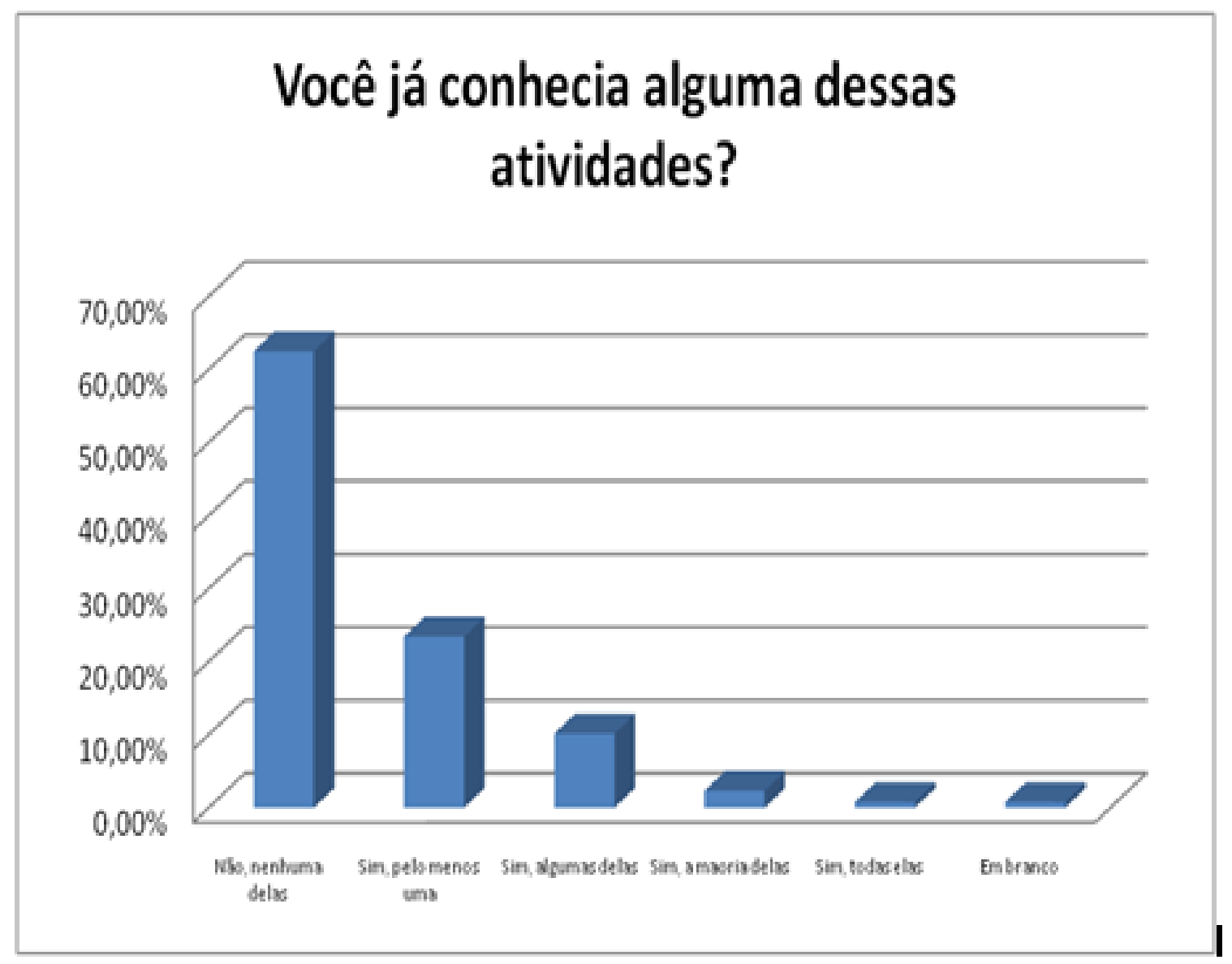

Figura 4.2: Porcentagem às respostas da questão 2.

Gráfico feito pelo autor com os dados obtidos do item 2. 
Da tabela 4.2 e do gráfico 4.2, pode-se inferir que a maioria dos professores não trabalham com atividades contextualizadas, práticas, diversificadas ou inovadoras em sala de aula, sempre mantendo o tradicional da apresentação da sala de aula e exercícios do livro didático. Assim, deve-se incentivar os professores a trabalharem mais com esse tipo de atividade para um melhor aproveitamento do conteúdo.

As opções C), D) e E) foram respondidas mais de uma vez, como um aluno que escreveu professor e internet.

Na tabela 4.3 e na figura 4.3, são apresentados os resultados das respostas dos estudantes à questão complementar à questão 2. Tal complementação refere-se ao local onde o estudante havia visto a atividade.

Tabela 4.3: Quantitativo de respostas à questão complementar à 2: As situações em que foram vistas as atividades: Caso tenha marcado as opções B, C, D ou E, descreva em qual situação conheceu a(s) atividade(s):

\begin{tabular}{l|r}
\hline Televisão & 1 \\
\hline Internet & 10 \\
\hline Sala de aula/professor & 35 \\
\hline Livros & 1 \\
\hline Outros & 3 \\
\hline
\end{tabular}

Desta pergunta, pode-se inferir que a maior parte das atividades que desenvolvem os conhecimentos é realizada em sala de aula, pelo professor, confirmando, novamente, as conclusões da tabela 4.2 e figura 4.2 . 


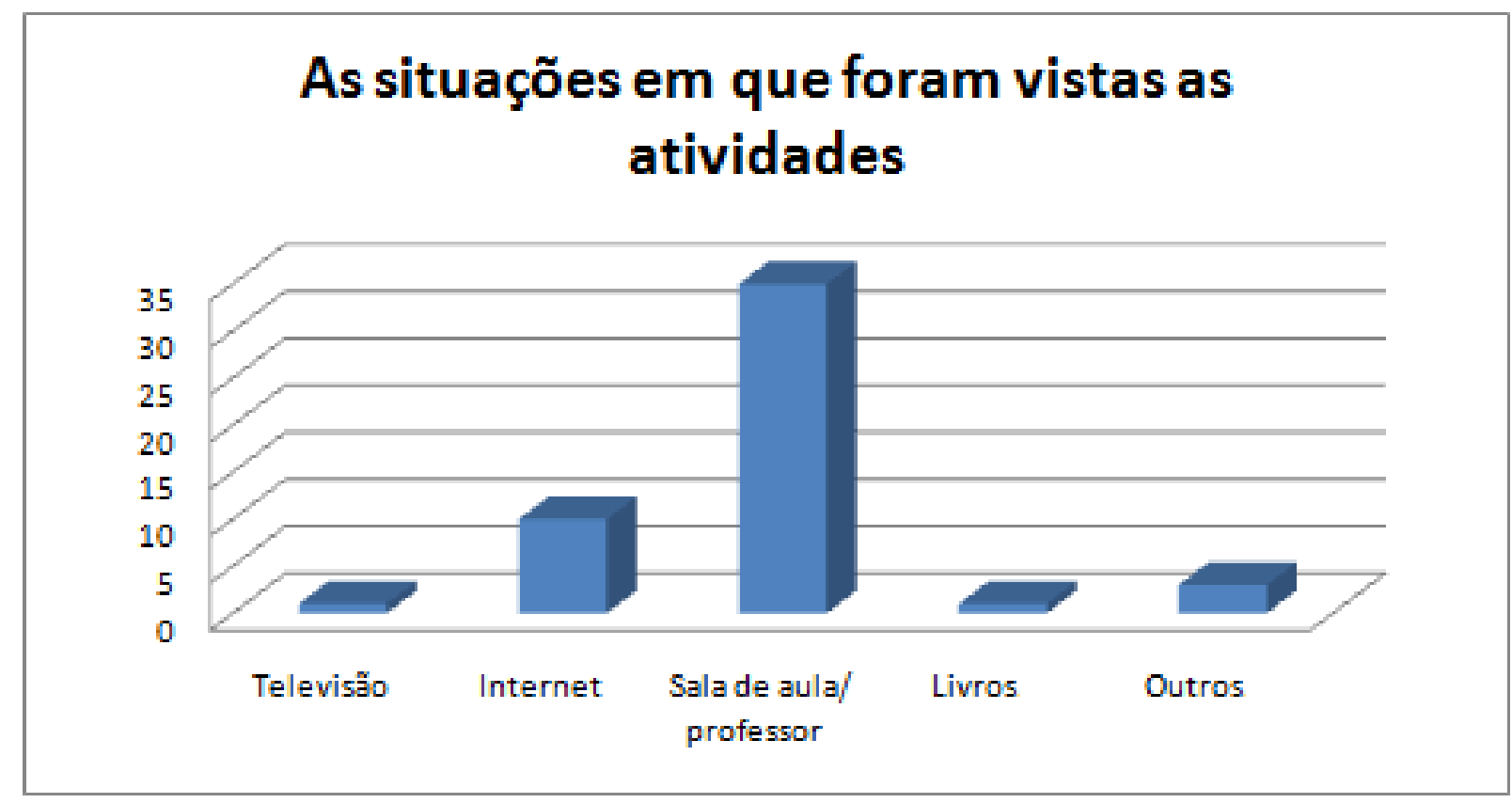

Figura 4.3: Gráfico das respostas à questão: descreva em qual situação conheceu a(s) atividade(s).

Gráfico feito pelo autor com os dados obtidos do item 2 complementar.

\subsection{Questão 3}

Na tabela 4.4 e na figura 4.4, são apresentados os resultados das respostas dos estudantes à questão 3 . 
Tabela 4.4: Quantitativo de respostas à questão 3: Marque as 2 atividades com que mais gostou de trabalhar e estudar.

\begin{tabular}{l|r}
\hline Opção & Número de marcações \\
\hline A) Atividades com jogo de dardo. & 34 \\
\hline B) Construção da ponte em miniatura. & 90 \\
\hline C) Cálculo da altura com sombras. & 5 \\
\hline D) Volume de prismas e pirâmides com barra de sabão. & 60 \\
\hline E) Volume da esfera a partir de um cilindro e um cone. & 8 \\
\hline F) Geometria do motorista de táxi. & 36 \\
\hline G) Geometria não Euclidiana da esfera. & 5 \\
\hline H) Criação de uma atividade. & 14 \\
\hline Anulados* & 2 \\
\hline
\end{tabular}

*Como o item pedia pra marcar as duas de que mais gostaram, houve dois questionários que marcaram mais de duas opções e foram anulados.

\section{Marque as $\mathbf{2}$ atividades com que mais gostou de trabalhar e estudar.}
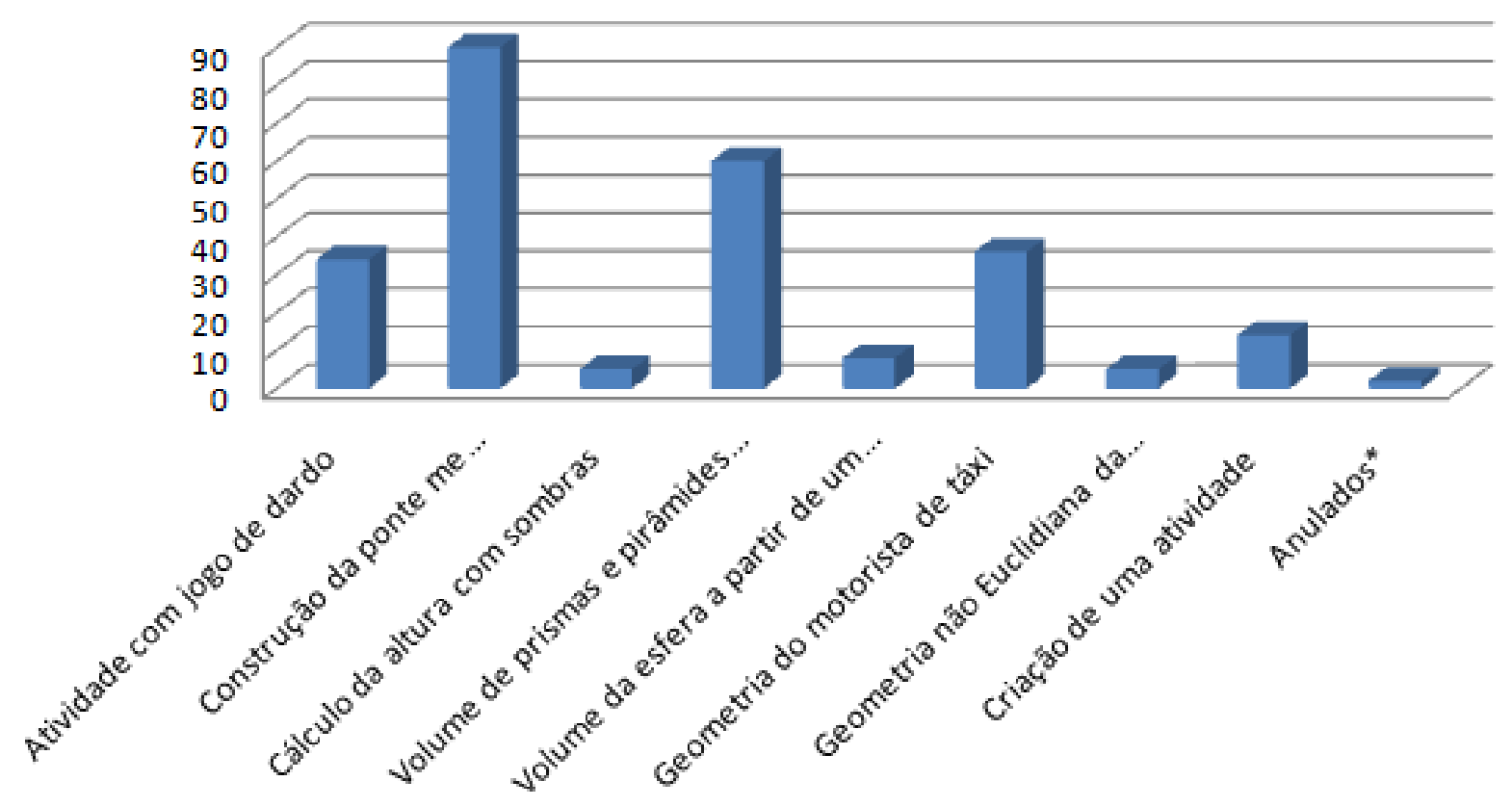

Figura 4.4: Quantitativo de respostas à questão 3.

Fonte: Gráfico feito pelo autor com os dados obtidos do item 3. 
Desta pergunta o que se pode inferir é que as atividades que tiveram a maioria dos alunos marcando como as que mais gostaram foram as atividades práticas: construção de ponte em miniatura e volume de prismas e pirâmides com barra de sabão. O que mostra que quanto mais eles conseguem "sentir"o que estão fazendo, se torna mais agradável estudar. Segundo Perrenoud (2000, pag. 17), "Administrar a progressão da aprendizagem mobiliza cinco competências mais específicas", das quais, destacam-se: "Conceber e administrar situações problemas ajustadas ao nível e possibilidades dos alunos" e "Estabelecer laços com as teorias subjacentes às atividades de aprendizagem".

\subsection{Questão 4}

Na tabela 4.5 e na figura 4.5, são apresentados os resultados das respostas dos estudantes à questão 4 .

Tabela 4.5: Quantitativo de respostas à questão 4: Quanto à atividade criada em sala pela turma, o que você percebeu?

\begin{tabular}{l|c|r}
\hline Opção & Número de marcações & Porcentagem aproximada \\
\hline $\begin{array}{l}\text { A) A turma não conseguiu criar } \\
\text { efetivamente uma atividade. }\end{array}$ & 32 & $25,00 \%$ \\
\hline $\begin{array}{l}\text { B) A atividade poderia ter sido } \\
\text { criada mesmo se não tivessem } \\
\text { sido apresentadas as outras ativi- } \\
\text { dades anteriormente. }\end{array}$ & 4 & $3,12 \%$ \\
\hline $\begin{array}{l}\text { C) As atividades propostas ante- } \\
\text { riomente ajudaram, de fato, a cri- } \\
\text { ação da atividade proposta pela }\end{array}$ & 83 & $64,84 \%$ \\
turma. & & \\
\hline Anulada* & & \\
\hline Em branco & & \\
\hline
\end{tabular}

*Anulada por ter marcado mais de uma opção.

Observações:

- duas turmas criaram a atividade, decidiram fazer todos juntos a mesma atividade;

- uma turma se dividiu em grupos e apenas um grupo conseguiu realizar a criação da atividade, e a outra parte se juntou à ideia do outro grupo para resolver a questão; 
- e uma turma não conseguiu, na totalidade, criar uma atividade.

\section{Quanto à atividade criada em sala pela turma, o que você percebeu?}

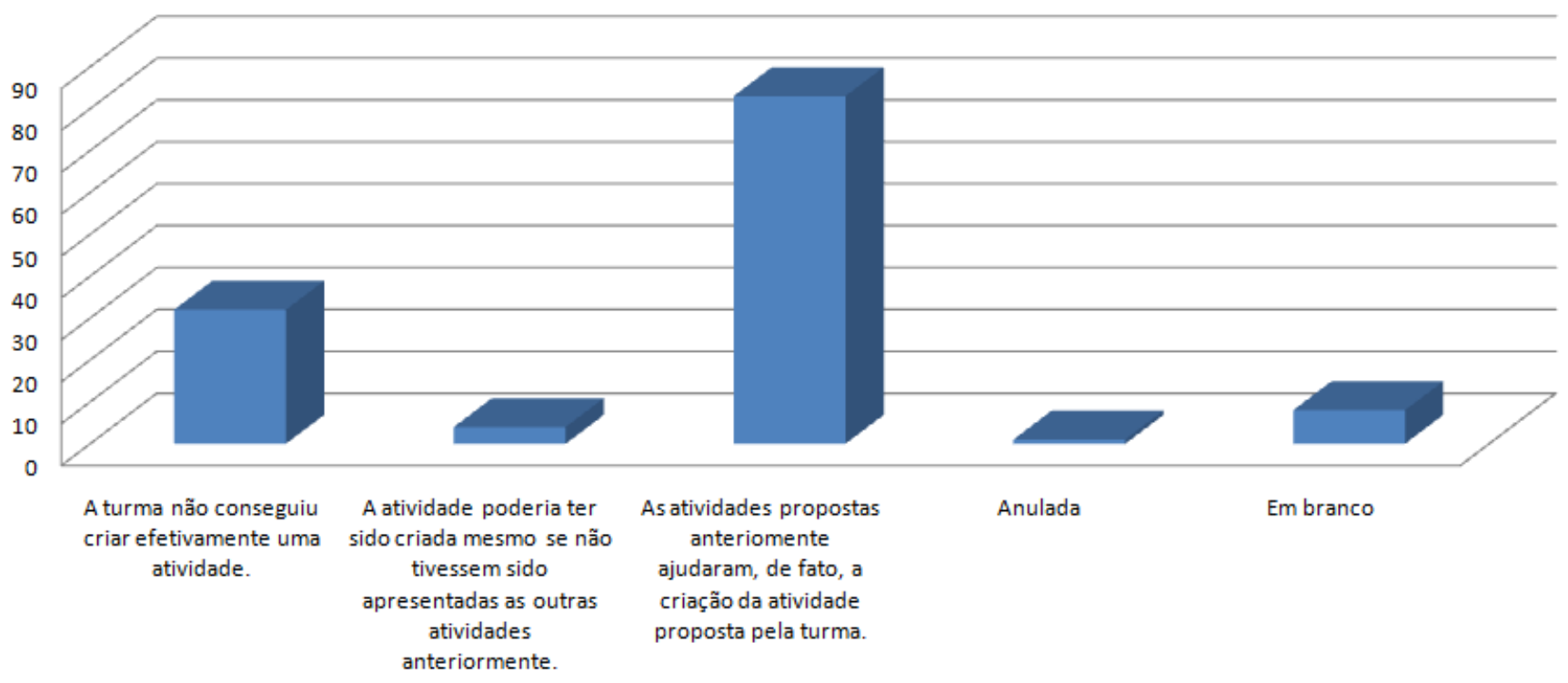

Figura 4.5: Quantitativo de respostas à questão 4: Quanto à atividade criada em sala pela turma, o que você percebeu? 


\subsubsection{Resumo das atividades criadas pelas turmas}

O professor da turma e o pesquisador ajudaram a elaborar o enunciado de forma a não ficar incompreensivo.

1. Em um papel quadriculado, estudar, de acordo com as posições colocadas, qual é o menor caminho, dada a posição inicial e final, sabendo que só pode se passar pelas "linhas", nunca por dentro dos quadrados em branco.

Conclusões a que a turma chegou:

- se a posição inicial estiver acima da final, o menor caminho é seguir sempre para "baixo"e o inverso pra "cima". Se a posição inicial estiver à direita da final, seguir o caminho da direita pra esquerda e o inverso da esquerda pra direita;

- em outras posições, bastam combinar se é acima e direita, abaixo e direita, acima e esquerda e abaixo e esquerda e fazer o mesmo raciocínio, acima direita é sempre para baixo e da direita pra esquerda. 


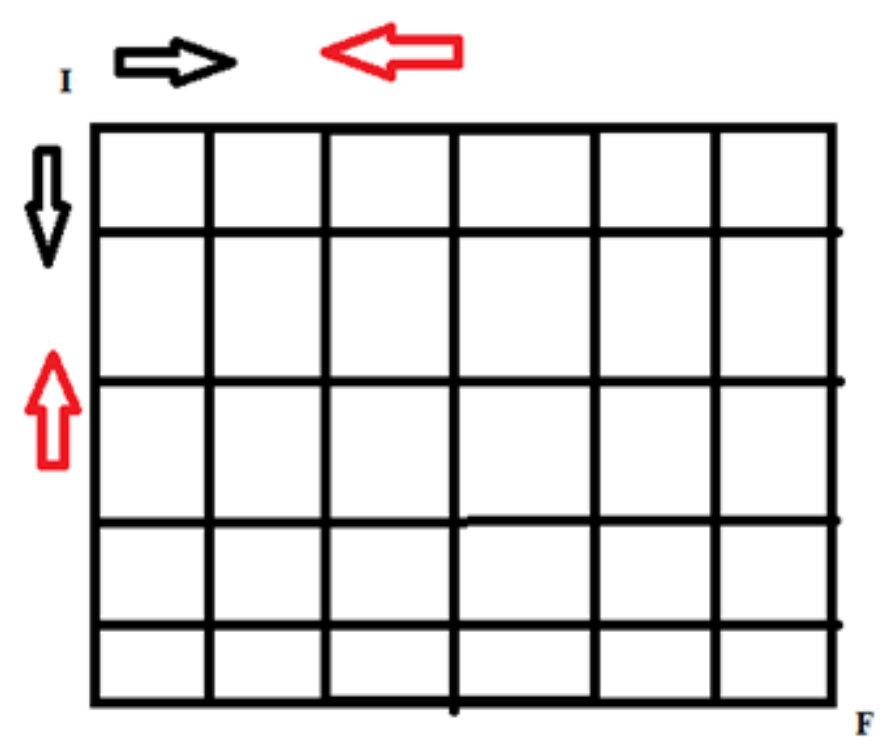

Figura 4.6: Exemplo da atividade, onde "I"é a posição inicial e "F", a posição final, as setas em preto são as direções que podem ser seguidas, e as setas em vermelho são as posições que não podem ser seguidas.

Observação: atividade inspirada na geometria do motorista de táxi.

2. Estudo de um jogo de "arco e flecha" feito pela própria turma. A turma decidiu que no centro do jogo seria um raio de $5 \mathrm{~cm}$ e os outros raios com medidas de $10 \mathrm{~cm}$, $15 \mathrm{~cm}, 20 \mathrm{~cm}, 25 \mathrm{~cm}$ e $30 \mathrm{~cm}$. E a partir dessas medidas calcularem as áreas das coroas circulares.

Para a resolução do item, os alunos calcularam todas as áreas representadas da seguinte forma:

- a área do primeiro círculo utilizando a fórmula $\pi\left(R_{1}\right)^{2}$, onde $R_{1}=5 \mathrm{~cm}$ chegando à resposta de $25 \pi \mathrm{cm}^{2} \approx 78,5 \mathrm{~cm}^{2}$ e as áreas utilizando a fórmula $\pi\left(R_{n}-R_{(n-}\right.$ 1)), com $n$ assumindo os valores $2,3,4,5,6$. Assim as áreas encontradas foram $75 \pi, 125 \pi, 175 \pi, 225 \pi$ e $275 \pi$, respectivamente.

Observação: atividade inspirada no jogo de dardo.

3. Parte de uma turma decidiu observar se podem ser feitos triângulos com mais de $180^{\circ}$ em objetos. Fez a experiência em um cilindro de papel e em um balão. E viu que é possível no balão formar tal triângulo e no cilindro ao planificá-lo (ao abrir o papel) forma um triângulo cuja a soma dos ângulos internos é igual 180 graus. 
Observação: essa atividade foi inspirada na atividade da geometria esférica de Rieman. Somente um grupo da turma criou essa atividade e outro grupo não conseguiu criar, mas decidiram resolver a mesma atividade e chegaram à mesma conclusão.

\subsubsection{Possíveis causas para a não realização da atividade por parte da turma}

Faltou algum estímulo (aquilo que anima, que incita a realização de algo). De acordo com Burrhus Frederic Skinner, em seu livro "Ciência e o comportamento Humano", um reforço positivo aumenta a probabilidade de um comportamento pela presença de uma recompensa, ou seja, um estímulo fortalece o resultado. Pensando por essa concepção de Skinner, a única recompensa que os alunos acima teriam com essa atividade é o conhecimento, pois não teve uma pontuação (nota, menção) para a realização da atividade, ou até mesmo algum brinde (bala, chocolate, entre outros). O reforço negativo é quando se remove algo desagradável, como, por exemplo, poderia citar a seguinte situação: o aluno que fizesse a atividade não precisaria ficar em sala de aula.

Os eventos que se verifica serem reforçadores são de dois tipos. Alguns reforços consistem na apresentação de estímulos, ao acréscimo de alguma coisa [...]. Outros consistem na remoção de alguma coisa [...]. Estes se denominam reforços negativos.

(SKINNER, 2003, pag. 81)

A atividade também não tinha nenhuma punição se não fosse realizada. Novamente, segundo Skinner, punição é um estímulo aversivo que reduz a probabilidade de um acontecimento. No caso apresentado pelas atividades, uma punição seria retirada dos pontos do bimestre e uma advertência. Essas atividades não apresentaram punição.

Para essa turma faltou alguma intervenção além do aprendizado dos conteúdos, que funcionou para as outras turmas. Essa intervenção deveria colaborar para a criatividade desses alunos e a possível realização da atividade.

Isso não quer dizer que a turma que não realizou a última atividade de criação não tenha aprendido ou aprendido menos do que as outras. Para isso, destacam-se duas formas de avaliação: a somativa e a processual. A primeira tem como objetivo a classificação dos alunos, sendo aplicada ao final; a segunda tem como objetivo avaliar se o aluno gradativamente domina cada etapa do conhecimento. A partir da observação dessas duas formas de avaliação, se aqui fosse dito que a turma que não conseguiu realizar a última atividade não havia aprendido, a avaliação somativa estaria sendo mais valorizada, ou seja, ao final 
do processo, quem não conseguiu resolver o problema não aprendeu o conteúdo. Mas as atividades realizadas devem ser vistas como um processo, os alunos participaram com um aproveitamento muito bom, desenvolveram as atividades anteriores tão bem como as outras turmas, resolveram os problemas anteriores e interagiram para o desenvolvimento do proposto. Analisando o processo, a turma foi capaz de realizar todas as atividades com exceção da última (criação da própria atividade). Tanto que essa turma não fez significativa diferença aos resultados da quinta pergunta - O que você aprendeu com essas atividades? (Pode marcar mais de uma resposta) - que será apresentada nos resultados abaixo como um resultado único. Eles desenvolveram as atividades com plena capacidade e apresentaram os resultados conforme as indicações feitas no capítulo 3.

Segundo Perrenoud:

Para gerir a progressão das aprendizagens, não se deve deixar de fazer balanços periódicos das aquisições dos alunos. Eles são essenciais para fundamentar decisões de aprovações ou de orientações necessárias mais tarde. Esta não é a única função, uma vez que devem contribuir para uma estratégia de ensino-aprendizagem em um grau ou em um ciclo.

Longe de constituir uma surpresa, esses balanços deveriam confirmar ou aprimorar o que o professor já sabe ou pressente. Portanto, não dispensar absolutamente uma observação contínua, da qual uma das funções é atualizar e contemplar uma das aquisições do aluno. Contrariamente ao que se crê, às vezes, a avaliação contínua preenche uma função cumulativa, até mesmo certificativa, porque nada substitui a observação dos alunos no trabalho, quando se quer conhecer suas competências [...].

(PERRENOUD, 2000.pag.49)

O questionário funcionou como uma atividade de autoavaliação, cujos resultados de aprendizagem estão na questão 5. Essas atividades, também, estão mais voltadas para o ensino e aprendizagem, do que classificar. Os alunos têm o papel de desempenhar as atividades de forma a obter o máximo de conhecimento ao desenvolver as atividades contextualizadas.

Evidentemente, a observação contínua não tem a função apenas de coletar dados com vistas a um balanço. Sua primeira intenção é a formativa, o que, em uma perspectiva pragmática, significa que considera tudo o que pode auxiliar o aluno a aprender melhor: suas aquisições, a quais condicionam as tarefas que lhe possam ser propostas, assim como a maneira de aprender e de raciocinar, 
sua relação com o saber, sua angústias e bloqueios eventuais diante de certos tipos de tarefas, o que faz sentido para ele e o que o mobiliza, seus interesses, seus projetos, sua auto-imagem como sujeito mais ou menos capaz de aprender, seu ambiente escolar e familiar.

(PERRENOUD, 2000.pag. 49-50)

\subsection{Questão 5}

Na tabela 4.6 e na figura 4.7, são apresentados os resultados das respostas dos estudantes à questão 5 .

Tabela 4.6: Quantitativo de respostas à questão 5: O que você aprendeu com essas atividades? (Pode marcar mais de uma resposta)

\begin{tabular}{l|l|l}
\hline Opção & $\begin{array}{l}\text { Número de mar- } \\
\text { cações }\end{array}$ & $\begin{array}{l}\text { Porcentagem } \\
\text { aproximada em } \\
\text { relação aos 128 } \\
\text { questionários. }\end{array}$ \\
\hline Definições básicas de ponto, reta e plano. & 94 & $73,44 \%$ \\
\hline Definição de círculo e setor circular. & 88 & $68,75 \%$ \\
\hline $\begin{array}{l}\text { Definição de retas perpendiculares, paralelas, con- } \\
\text { correntes e projeção. }\end{array}$ & 96 & $75,00 \%$ \\
\hline $\begin{array}{l}\text { Cálculos que envolvem progressão aritmética e ge- } \\
\text { ométrica. }\end{array}$ & 11 & $8,59 \%$ \\
\hline Semelhança e proporção de figuras. & 84 & $65,63 \%$ \\
\hline Operações com sistemas lineares. & 7 & $5,47 \%$ \\
\hline Cálculos de volumes. & 96 & $75,00 \%$ \\
\hline Outros conteúdos. & 74 & $57,81 \%$ \\
\hline
\end{tabular}




\section{5. $O$ que você aprendeu com essas atividades?}

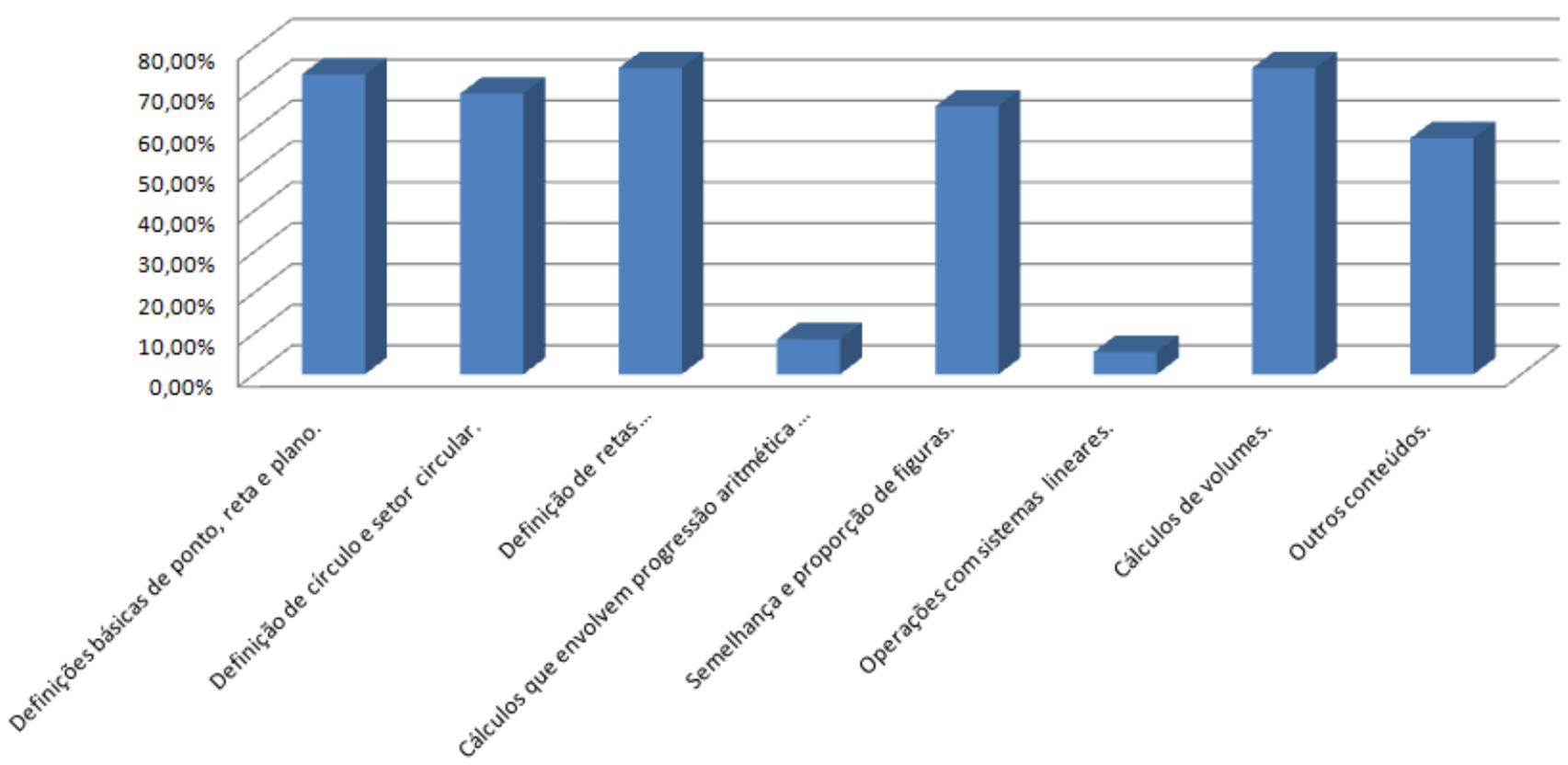

Figura 4.7: Porcentagem às respostas da questão 5.

Entre os outros conteúdos, foram citados os seguintes:

- Princípio de Cavalieri com 33 citações;

- Geometria do motorista de táxi com 33 citações;

- Geometria esférica (Rieman) com 23 citações;

- Geometria espacial com 1 citação.

Observação: alguns citaram mais de um conteúdo na opção "outros conteúdos", e outros marcaram essa opção, mas não escreveram o conteúdo.

As opções "cálculos que envolvem progressões aritméticas e geométricas"e "operações com sistemas lineares" foram inseridas pelo pesquisador no questionário como uma alternativa que, a princípio, não deveria ser marcada, pois não foram apresentadas nas atividades. No entanto, observou-se um quantitativo razoável de estudantes que escolheram essas opções, talvez por não terem feito uma leitura atenta da questão, ou por acharem que todos os conteúdos listados deveriam ter sido apreendidos, entre outros fatores que se devem considerar em que ocorrem erros em respostas a questionários.

As alternativas dos itens de aprendizado foram assinaladas por mais de $65 \%$ dos alunos. Isso mostra a percepção dos estudantes sobre o bom aprendizado dos conteúdos, visto que 
alguns nem estiveram presentes em todas as atividades, uma realidade encontrada pelo pesquisador ao aplicar as atividades, visto que estão matriculados entre 35 (trinta e cinco) a 42 (quarenta e dois) alunos por turma. Assim, o total de questionários respondidos deveria ser maior que 140 .

Outra importante observação que pode ser retirada das respostas aos questionários é que muitos conseguiram identificar o nome do conteúdo da atividade aplicada. Ou seja, com a primeira atividade, o estudante conseguiu relacionar que estava trabalhando circunferência e círculo e marcou a opção correspondente, dentre os outros itens apontados na questão, o que para muitos não é fácil de se fazer.

Um fato que se mostrou interessante foi ter sido assinalado mais vezes o item progressão aritmética e geométrica do que o item sistemas lineares, pois ambos não deveriam ser marcados. Acredita-se que a palavra geométrica seja um atrativo dentre as duas opções.

\subsection{Questão 6}

O item 6 era de resposta livre, um espaço no qual o estudante poderia comentar o que desejasse a respeito das atividades desenvolvidas. Para a análise dessas respostas, utilizou-se a metodologia proposta por Bardin, relativa à análise de conteúdo. Segundo Bardin:

A abordagem não quantitativa recorre a indicadores frequenciais susceptíveis de permitir inferências: por exemplo, a presença (ou ausência) pode constituir um índice tanto ou mais frutífero que a frequência de aparição.

(BARDIN, 1977.pag. 114).

O item 6 teve algumas frases que serão destacadas. O enunciado do item:

6. Use o espaço abaixo para algum comentário extra que você queria fazer sobre as atividades desenvolvidas.

Segundo Bardin (1977, pag. 119) para "decodificar seu material, deve-se produzir um sistema de categorias". Na tabela seguinte, estarão à esquerda as categorias e à direita exemplos de frases (as frases estão em anexo). 
Tabela 4.7: Categorias e exemplos de frases.

\begin{tabular}{|c|c|}
\hline Categorias & Exemplos de frases \\
\hline Local diferenciado para o ensino & $\begin{array}{l}\text { Foi uma atividade diferenciada e criativa, } \\
\text { sendo legal no laboratório. } \\
\text { Gostei muito das atividades desenvolvidas } \\
\text { dentro do laboratório, pois atividades exer- } \\
\text { cidas pelo professor dentro de sala as vezes } \\
\text { deixamos muito confusos e as atividades mos- } \\
\text { trou como é fácil e simples. }\end{array}$ \\
\hline Interação com os alunos & $\begin{array}{l}\text { Melhorou muito a dinâmica da turma e das } \\
\text { aulas, quero mais vezes. } \\
\text { Atividades muito bem elaboradas que deixa- } \\
\text { ram a turma empolgada pra participar. Pa- } \\
\text { rabéns. }\end{array}$ \\
\hline Estímulo ao estudo & $\begin{array}{l}\text { Sim, muito bom que poderia se repetir mais } \\
\text { vezes vai ajudar muito. } \\
\text { Uma atividade criativa e diferente e deixou } \\
\text { matemática mais divertida. }\end{array}$ \\
\hline Aulas diferenciadas & $\begin{array}{l}\text { Foi muito sensacional os exemplos que deu e } \\
\text { nunca tive uma aula tão bacana de matemá- } \\
\text { tica igual essa. }\end{array}$ \\
\hline Prática da geometria não Euclidiana & Muito interessante a motorista de táxi. \\
\hline Aperfeiçoamento do conhecimento & $\begin{array}{l}\text { O aprendizado é mais eficaz quando se usa } \\
\text { a prática. As atividades foram interessantes } \\
\text { e colaborou de forma produtiva no conheci- } \\
\text { mento. } \\
\text { Achei muito legal por causa da interação, fez } \\
\text { com que despertasse a vontade de aprender. }\end{array}$ \\
\hline Atividades práticas e dinâmicas & $\begin{array}{l}\text { Ter mais atividades dinâmicas, para desen- } \\
\text { volver a matéria de um jeito diferente. } \\
\text { Gostei, principalmente o da ponte e a do sa- } \\
\text { bão. Interessante. }\end{array}$ \\
\hline
\end{tabular}

Como uma análise das categorias, pode-se inferir que:

- o estudante gosta de locais diferentes para o ensino, assim o professor deve buscar locais diferentes para estimular o aprendizado, e as atividades contextualizadas podem fazer com que o aluno já veja a atividade em locais diferentes, como o laboratório, o pátio da escola, a quadra de esportes, entre outras;

- essas atividades também aumentam a interação com os alunos, não ficam somente em exposição do conteúdo e resolução de exercícios. A interação faz com que o aluno tenha mais afetividade com a matéria; 
- as aulas não ficam somente em exposição de conteúdo e resolução de exercícios. Também fazem com que se aperfeiçoem conteúdos extracurriculares, podendo se também fazer a interdisciplinaridade de conteúdos;

- a visão do aluno somente no quadro dificulta muito a compreensão de conteúdos, principalmente na geometria espacial, portanto as atividades práticas fazem com que o aprendizado seja melhorado. E, posteriormente, facilite sua visão do objeto no papel ou no quadro.

Desses pontos inferidos, pode-se observar o modelo da Escola da Ponte, em Portugual, que mudou os espaços e o tempo para o melhor aprendizado do aluno.

O derrubar das paredes libertou alunos e professores da rigidez dos espaços tradicionais e acompanhou o derrube de outros muros. Em conjunto com as alterações arquitectónicas atrás referidas, outras opções organizacionais marcaram a ruptura com o modelo tradicional de organização da escola, que considerávamos não respeitar as individualidades e não favorecer o sucesso de todos.

(PACHECO, 2001. p.66)

A busca por inovação, contextualização, uma avaliação formativa, entre outros pontos, faz com que o aluno melhore o que se aprende e como se aprende. 


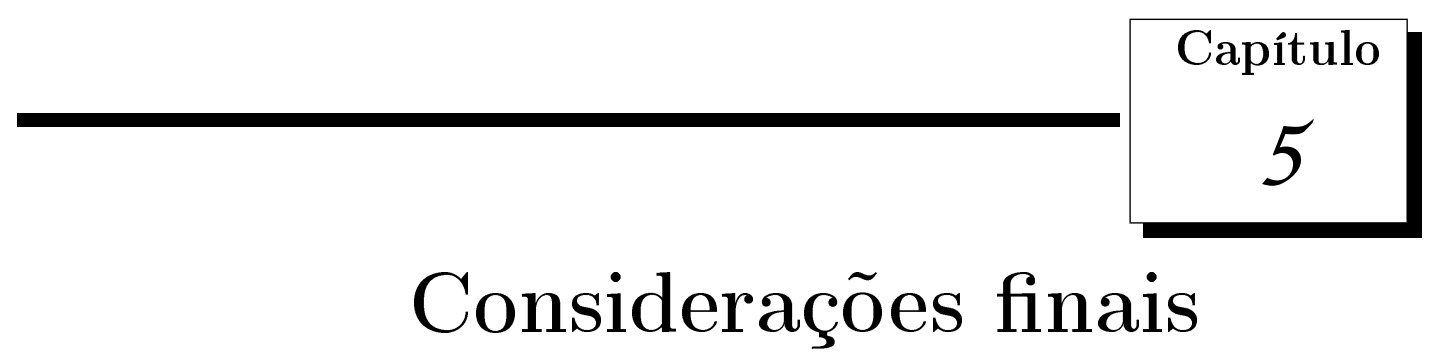

Ao se iniciar o estudo sobre o desempenho dos estudantes nas avaliações nacionais de larga escala, foi confirmado que os alunos apresentam baixo desempenho nos conteúdos geométricos e, como consequência, altos índices de reprovação e baixo aprendizado em matemática. A partir dessa análise, verificou-se a importância de um trabalho pedagógico diferenciado, e, assim, a contextualização emergiu como uma importante ferramenta de pesquisa sobre o desenvolvimento dos conteúdos em geometria, com o intuito de motivar os estudantes, e de, posteriormente, ser aplicada em outras áreas da matemática. No entanto, o trabalho de forma contextualizada esbarra em algumas dificuldades, tais como:

- a forma passiva do professor de trabalhar somente com o livro didático;

- a falta de recursos materiais nas escolas;

- o desinteresse dos professores em relacionar a matemática com outras disciplinas;

- a necessidade de aperfeiçoamento do professor, que, em muitos casos, carece de incentivo.

O trabalho diferenciado e contextualizado faz com que os alunos acostumem-se com um aprendizado interdisciplinar, aprendendo a relacionar o conteúdo escolar com os temas do cotidiano, abrindo a mente para várias dimensões do conhecimento, não somente profissionalizante. Isso minimiza a quantidade de perguntas que sempre são feitas pelo estudante ao professor de matemática, no sentido de saber para que serve determinado conteúdo, além de motivar e refletir nos resultados de sua aprendizagem, colaborando com o dilema vivenciado nas escolas de, ao mesmo tempo que se reconhece a importância do 
ensino da matemática, os resultados são, geralmente, insatisfatórios quanto à aprendizagem. Assim, deve-se fazer com que o estudante tenha o saber, pois o saber é algo que irá carregar por toda sua vida, desenvolvendo habilidades cognitivas.

\subsection{Considerações sobre as avaliações nacionais}

Os exemplos 1 e 2 (referentes ao Saeb) do capítulo 1, nos quais os alunos são convidados a resolver um problema apresentado em contexto simples, aplicando seus conhecimentos geométricos/matemáticos, revelaram a grande dificuldade dos estudantes em achar a solução correta, o que mostra que eles não estão familiarizados com uma avaliação elaborada nessa perspectiva. Como os exames nacionais estão apresentando as questões de forma que o aluno tenha de interpretá-las a partir de uma situação contextualizada, conforme mostra o exemplo 3 (Figura 1.7: Questão 142 - ENEM 2014), há necessidade de se desenvolver essa capacidade durante a formação escolar. Assim, mostra-se que essa forma de trabalhar deve ser incentivada entre os professores, para melhorar a performance dos alunos nas avaliações nacionais, em especial no ENEM, principal porta atual de acesso ao ensino superior brasileiro.

\subsection{Considerações sobre as atividades aplicadas}

O trabalho aqui desenvolvido mostrou, mesmo que de forma preliminar, algumas vantagens de trazer a contextualização dos conteúdos de matemática, especificamente da geometria, para dentro da sala de aula, favorecendo o despertar de um interesse maior para o aprendizado da matemática e a apreensão dos conteúdos.

A análise quantitativa (5 primeiras perguntas) e a qualitativa (sexta pergunta) das respostas dos estudantes ao questionário revelou que:

- os alunos gostam e têm interesse em trabalhar de forma contextualizada e com metodologia diferente da tradicional, pois acham bom saber onde surgiram os conceitos e ter disponível à sua frente um objeto concreto para trabalhar a matemática;

- os alunos gostam de interagir com os colegas e de trabalhar de forma cooperativa, melhorando a dinâmica de funcionamento da aula;

- poucas vezes ao longo da formação escolar, a geometria foi trabalhada de forma diferente do modelo tradicional; 
- a aula tradicional, no modelo transmissão-recepção, mesmo com a resolução de exercícios do livro, é entediante.

A opinião dos estudantes, evidenciada nos questionários, sinaliza que está passando da hora de mudarmos a forma com que se ensina a matemática, havendo necessidade de um trabalho pedagógico diferenciado que faz o aluno progredir melhor no seu aprendizado, tornando-o mais estimulado para a busca do conhecimento, formando sujeitos mais bem preparados do ponto de vista pessoal e profissional. Isso não quer dizer, de forma alguma, que se deve abandonar o livro didático e a sala de aula tradicional, mas, sim, diversificar as ações pedagógicas, abandonando um modelo único e trabalhando de maneiras complementares, tornando o trabalho em sala de aula mais produtivo, instigante e dinâmico.

O trabalho desenvolvido sugere também que a avaliação em matemática não deva se restringir ao modelo tradicional, somativo, mas ser desenvolvida na perspectiva formativa, interdisciplinar e contextualizada, que observe atentamente os conhecimentos adquiridos e as dificuldades de aprendizagem dos estudantes, fazendo-se, durante o processo, a devida intervenção para que seu conhecimento seja pleno. Assim, todos serão beneficiados e, consequentemente, atingirão melhores resultados nas avaliações de aprendizagem de sala de aula e, posteriormente, nas avaliações nacionais, vestibulares e até em concursos públicos futuros, pois aprenderão a relacionar os conteúdos escolares com atividades cotidianas, uma competência indispensável para o sucesso profissional futuro. 


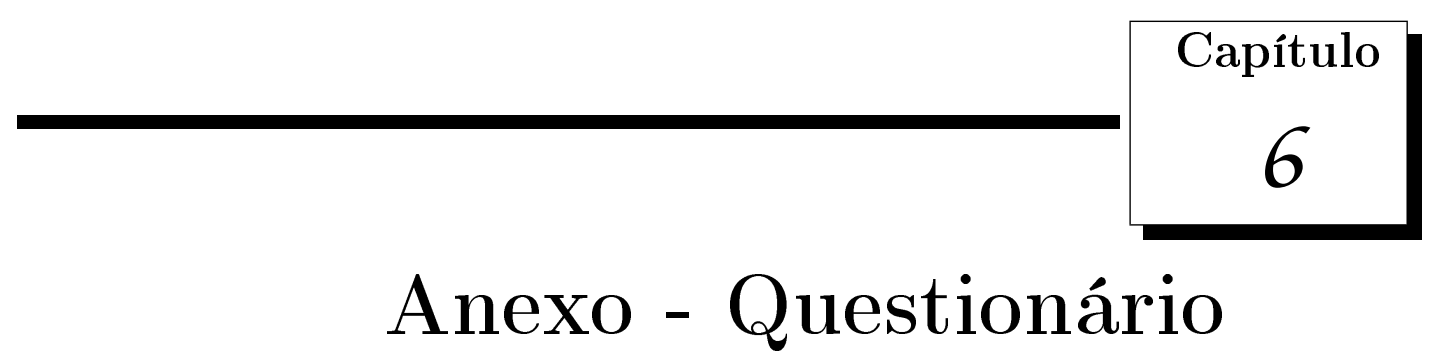

QUESTIONÁRIO

(Aplicado ao final da atividade 8)

Este questionário tem o objetivo principal de descobrir se a dificuldade de se aprender matemática está relacionada com o ensino dos conceitos de forma descontextualizada e distanciada da vida cotidiana do aluno. Os resultados obtidos serão apresentados sob forma de uma dissertação para conclusão do curso de Mestrado Profissional em Matemática em Rede Nacional (Profmat) da Universidade de Brasília (UnB). Agradecemos sua valiosa colaboração e informamos que os dados serão apresentados por meio de análises estatísticas, sendo garantido o anonimato dos respondentes.

Atenciosamente,

André Luis Santos Martinez.

Com relação às atividades de 1 a 8 desenvolvidas em sala de aula, marque a alternativa que melhor corresponde ao seu rendimento nas atividades.

1. Seu interesse pelas atividades foi
A) ( ) muito baixo.
B) ( ) baixo.
C) ( ) regular.
D) ( ) bom.
E) ( ) muito bom. 
2. Você já conhecia alguma dessas atividades?

A) ( ) Não, nenhuma delas.

B) ( ) Sim, pelo menos uma.

C) ( ) Sim, algumas delas.

D) ( ) Sim, a maioria delas.

E) ( ) Sim, todas elas.

Caso tenha marcado as opções B, C, D ou E, descreva em qual situação conheceu a(s) ati$\operatorname{vidade}(\mathrm{s})$ :

3. Marque as 2 atividades com que mais gostou de trabalhar e estudar.

A) ( ) Atividades com o jogo de dardo.

B) ( ) Construção da ponte em miniatura.

C) ( ) Cálculo da altura com sombras.

D) ( ) Volume de prismas e pirâmides com barra de sabão.

E) ( ) Volume da esfera a partir de um cilindro e um cone.

F) ( ) Geometria do motorista de táxi.

$\mathrm{G})($ ) Geometria não euclidiana da esfera.

H) ( ) Criação de uma atividade.

4. Quanto à atividade criada em sala pela turma, o que você percebeu?

A) ( ) A turma não conseguiu criar efetivamente uma atividade.

B) ( ) A atividade poderia ter sido criada, mesmo se não tivessem sido apresentadas as outras atividades anteriormente.

C) ( ) As atividades propostas anteriormente ajudaram, de fato, a criação da atividade proposta pela turma.

5. O que você aprendeu com essas atividades? (Pode marcar mais de uma resposta)

( ) Definições básicas de ponto, reta, plano.

( ) Definição de círculo e setor circular.

( ) Definição de retas perpendiculares, paralelas, concorrentes e projeção.

( ) Cálculos que envolvem progressões aritméticas e geométricas.

( )Semelhança e proporção de figuras.

( ) Operações com sistemas lineares.

( ) Cálculo de volumes.

( ) Outros conteúdos: 
6. Use o espaço abaixo para algum comentário extra que você queira fazer sobre as atividades desenvolvidas.

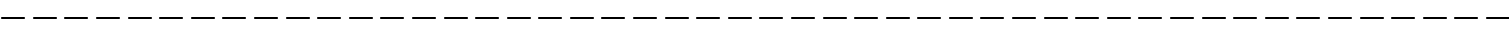




\section{$\longrightarrow$ \\ Anexo - Respostas à questão 6}

\section{Respostas referentes à questão 6:}

- Adorei, tinha que trabalhar mais isso.

- Foi muito bem desenvolvidas as atividades, e deveria ser praticadas não só essa como outras para uma certa experiência adquirida.

- Foi uma atividade diferenciada e criativa, sendo legal no laboratório.

- Gostei muito das atividades desenvolvidas dentro do laboratório, pois atividades exercidas pelo professor dentro de sala as vezes deixamos muito confusos e as atividades mostrou como é fácil e simples.

- Legal. E sim, seria interessante mais atividades como essa.

- Sim, muito bom que poderia se repetir mais vezes vai ajudar muito.

- Gostei das atividades apresentadas e gostaria que tivessem mais aulas assim.

- As atividades desenvolvidas contribuíram para meu aprendizado. Seria interessante se tivéssemos mais aulas assim.

- Uma atividade criativa e diferente e deixou matemática mais divertida.

- Gostei, poderíamos trabalhar assim mais vezes.

- Seria mais importante trabalhar essa atividade, ajudaria a compreender mais sobre o dia-a-dia. 
- Gostei muito, poderia ter mais aulas assim.

- Gostei, poderia usar mais esse tipo de atividade.

- Foi proveitoso e devia continuar para ajudar nos conteúdos já vistos e não entendidos.

- Gostei bastante, seria interessante termos mais aulas deste modelo.

- Gostei de ver a matemática na prática não somente no papel, gostaria de ter mais aulas práticas e um pouco mais de interesse da turma.

- De acordo com a aula oferecida, poderia ter aprofundado mais nos cálculos do volume.

- Eu achei interessante todas as atividades, e seria melhor se as aulas de matemática fossem sempre assim.

- Gostei mas deveria ter mais deveres com objetos.

- Poderiam permitir um melhor aproveitamento nas aulas.

- Essas atividades foram interessantes por ensinarem a calcular áreas de forma mais fácil.

- Melhorou muito a dinâmica da turma e das aulas, quero mais vezes.

- Eu gostei, gostaria que tivesse mais atividades assim.

- O aprendizado é mais eficaz quando se usa a prática. As atividades foram interessantes e colaborou de forma produtiva no conhecimento.

- Este método de aula é muito melhor, pois assim temos mais interesse.

- Gostei, porque não tinha feito essas atividades práticas.

- Eu gostei de fazer a ponte de macarrão, nunca pensaria nisso. E o professor explica bem e com calma o conteúdo dado.

- Gostei, principalmente o da ponte e a do sabão. Interessante.

- As atividades foram realizadas de uma forma em que alguns aprenderam, e aprenderam algo a mais.

- Muito interessante a motorista de táxi. 
- Atividades muito bem elaboradas que deixaram a turma empolgada pra participar. Parabéns.

- Com base nas aulas, nós podemos aumentar nossos conhecimentos de coisas que já poderíamos ter visto na sala de aula.

- Gostei bastante, legal aprender com essa dinâmica.

- Gostei bastante, dinâmico pois tinha atividades práticas.

- Muito legal, interessante a forma de ensinar e interagir com os alunos.

- Foi legal, porque o professor soube explicar e interagir bem com a turma.

- Foi muito sensacional os exemplos que deu e nunca tive uma aula tão bacana de matemática igual essa.

- Achei muito legal por causa da interação, fez com que despertasse a vontade de aprender.

- Deveriam ter mais, pois o aprendizado é mais rápido e com facilidade de aprender a matéria.

- Ter mais atividades dinâmicas, para desenvolver a matéria de um jeito diferente.

- Achei muito legal e criativo e tive um grande aprendizado, também novas experiências. 


\section{Referências Bibliográficas}

[1] BARDIN, L. Análise de conteúdo. Lisboa. 1979.

[2] BRASIL. Ministério da Educação. Parâmetros Curriculares Nacionais 5a a 8a série do ensino fundamental: Matemática. Brasília, DF, 1998.

[3] BRASIL. Ministério da Educação. Parâmetros Curriculares Nacionais: Ensino médio: Parte III: Ciências da Natureza, Matemática e suas Tecnologias. Brasília, DF, 1998.

[4] BRASIL. Ministério da educação. Instituto Nacional de Estudos e Pesquisas Educacionais Anísio Teixeira- INEP. Edital $N^{o}$ 6, De 15 de maio de 2015 exame nacional do ensino médio - ENEM 2015.

[5] CARVALHO, P.C.P Introdução à Geometria Espacial. Coleção do professor de matemática. SBM. 1993.

[6] DANTE, L.R. Matemática Contexto e Aplicações Volume 2 . Ed. ática. 2011.

[7] DOLCE, O. e POMPEO, J.N. Fundamentos de Matemática Elementar. Volume 9. Atual editora. $7^{a}$ ed.1997

[8] DOLCE, O. e POMPEO, J.N. Fundamentos de Matemática Elementar. Volume 10. Atual editora. $7^{a}$ ed. 2013

[9] D'AMBrosio, Ubiratan. Sociedade, cultura, matemática e seu ensino. Educ. Pesqui., São Paulo, v. 31, n. 1, p. 99-120, mar. 2005 . Disponível em http://www.scielo.br/scielo.php?script=sci_arttext\&pid=S151797022005000100008\&lng=pt\&nrm=iso. Acesso em 16 nov de 2015.

[10] D'AMBRÓSIO, Ubiratan. Da Realidade à Ação - reflexões sobre educação e matemática, ed. Campinas - SP: Ed. Da Universidade Estadual de Campinas, 1986. 
[11] D'AMBRÓSIO, Ubiratan. Educação Matemática: da teoria à prática, ed. Campinas, SP: Papirus, 2012.

[12] GUARESCHI, P. Sociologia crítica: alternativas de mudança. 59a edição. EDIPUCRS. 2005.

[13] GREENBERG M.J. Euclidean and non-Euclidian geometries. Devevelopment na History. Third edition. University of California, Santa Cruz.1994.

[14] MARTINI, M. L., PRETTE, Z.A.P. Atribuições de Causalidade e Afetividade de Alunos de Alto e Baixo Desempenho Acadêmico em Situações de Sucesso e de Fracasso Escolar. Revista Interamericana de Psicologia/Interamerican Journal of Psychology - 2005, Vol. 39, Num. 3 pp. 355-368. Universidade de São Carlos, Brasil. 2005.

[15] PACHECO, J. Fazer a Ponte. Vila das Aves, Junho de 2001. Em: Rui Canário, Filomena Matos e Rui Trindade(Orgs.)Escola da Ponte: Defender a Escola Pública.

[16] PAIVA, M.L.M.F., BORUCHOVITH, E. Orientações motivacionais, crenças educacionais e desempenho escolar de estudantes do ensino fundamental. Psicologia em Estudo, Maringá, v. 15, n. 2, p. 381-389, abr./jun. 2010.

[17] PAVANELlO, R.M. O abandono de ensino de geometria: uma visão histórica. Dissertação mestrado, Universidade Estadual de Campinas, UNICAMP, 1989. Fonte: http://www.bibliotecadigital.unicamp.br/document/?code=vtls000045423\&fd =y

[18] PERRENOUd, Ph. (2000). Dez Novas Competências para Ensinar. Porto Alegre: Artmed Editora (trad. en portugais de Dix nouvelles compétences pour enseigner. Invitation au voyage. Paris: ESF, 1999).

[19] RABELO, M. Avaliação educacional: fundamentos, metodologia e aplicações no contexto brasileiro. Rio de Janeiro: SBM, 2013.

[20] SKINNER, B. F. Ciência e comportamento Humano. Martins Fontes. 2003

[21] http://basenacionalcomum.mec.gov.br/\#/site/base/o-que [acesso em 16/10/2015]

[22] www.fnde.gov.br/programas/livro-didatico [acesso em 16/10/2015]

[23] http://michaelis.uol.com.br/ [acesso em 21/10/2015]

[24] http://download.inep.gov.br/educacao_basica/prova_brasil_saeb/menu_do_gestor/exemplos_qu estoes/M08_Saeb_site_FP.pdf 
[25] http://simposio.profmat-sbm.org.br/docs/Mesa-redonda-MauroRabelo.pdf.

[26] http://www.aulafacil.com/cursos/110836/ciencia/matematicas/areasgeometricas / calculo-del-area-de-un-segmento-circular

[27] http://euler.mat.ufrgs.br/ ensino2/ano2006/alunos/31/setor2.html

[28] http://pt.dreamstime.com/fotos-de-stock-royalty-free-dardos-profissionaisimage26473938, acesso em 02/02/2016

[29] https://www.portaldasescolas.pt 